A FEA e a USP respeitam os direitos autorais deste trabalho. Nós acreditamos que a melhor proteção contra o uso ilegítimo deste tex to é a publicação online. Além de preservar o conteúdo motiva-nos oferecer à sociedade o conhecimento produzido no âmbito da universidade pública e dar publicidade ao esforço do pesquisador. Entretanto, caso não seja do intercsse do autor manter o documento online, pedimos compreensão em relação à iniciativa e o contato pelo e-mail bibfea@usp.br para que possamos tomar as providências cabiveis (remoção da tese ou dissertação da BDTD). 
UNIVERSIDADE DE SÃO PAULO

FACULDADE DE ECONOMIA, ADMINISTRAÇÃO E CONTABILIDADE PROGRAMA DE PÓS-GRADUAÇÃO EM ADMINISTRAÇÃO

\section{APLICAÇÃO DE SISTEMA DE GESTÃO DO CONHECIMENTO PARA O DESENVOLVIMENTO DE COMPETÊNCIAS: UM ESTUDO DE CASO EM EMPRESA DO SETOR DE SERVIÇOS}

DENISE A. LUSTRI

Orientadora: Prof ${ }^{a}$ Dra. Irene K. Miura 


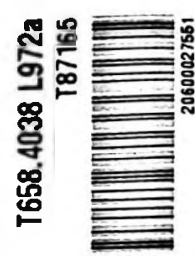

苔 


\section{DENISE A. LUSTRI}

\section{APLICAÇÃO DE SISTEMA DE GESTÃO DO \\ CONHECIMENTO PARA O DESENVOLVIMENTO DE COMPETÊNCIAS: UM ESTUDO DE CASO EM EMPRESA DO SETOR DE SERVIÇOS}

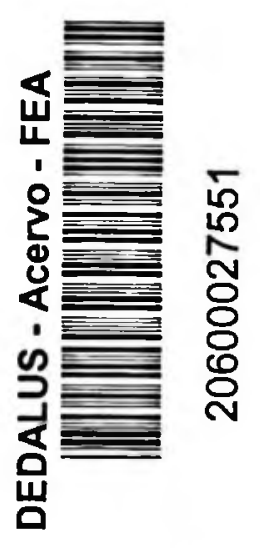

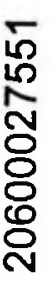

Dissertação apresentada à Faculdade de Economia, Administração e Contabilidade da Universidade de São Paulo para a obtenção do título de Mestre em Administração pelo Curso de PósGraduação em Administração.

Orientadora: Prof ${ }^{\mathrm{a}}$ Dra. Irene K. Miura

\begin{tabular}{|l|l|}
\hline USP - FEA - SBD \\
DATA DA DEFESA O 1,03 & 05 \\
\hline
\end{tabular}

\section{SÃo PaUlo}

2005

87165 
Dissertação defendida e aprovada, em 01.03.2005, no Programa de Pós-Graduação em Administração, pela seguinte comissão julgadora:

Prof Dr" Irene Kazumi Miura

Prof. Dr. Sergio Takahashi

Prof. Dr. Roberto Gonzáles Duarte

\section{FICHA CATALOGRÁFICA}

Elaborada pela Seção de Publicações e Divulgação do SBD/FEAVUSP

\section{Lustri, Denise A}

Aplicaç̧̃o de sistema de geståo do conhecimento para o desenvolvimento de competências: um estudo de caso em empresa do setor de serviços / Denise A. Lustri - São Paulo, 2005.

$171 \mathrm{p}$.

Dissertaçăo (Mestrado) - Universidade de São Paulo, 2005 Bibliografia.

1. Gestão do conhecimento 2. Gestão por competências 3. Serviços I. Universidade de São Paulo. Faculdade de Economia, Administração e Contabilidade da USP II. Título. 


\section{DEDICATÓRIA}

Aos meus pais, por todo o esforço para a minha formação e educação, por construírem a base para que eu pudesse chegar até aqui.

A minha filha, Gabriela, por todo o carinho, compreensão e apoio que sempre fizeram parte da nossa relação, mas se intensificaram nos momentos mais dificeis desta trajetória, tormando a travessia mais tranqüila.

Ao Mário, pelo companheirismo, pelo apoio, por compreender e aceitar as horas diminuídas do nosso convívio para que este trabalho fosse realizado.

Ao meu irmão, Rogério, por suas orientações e por seu exemplo brilhante que me inspirou a dar os primeiros passos na vida acadêmica. 


\section{AGRADECIMENTOS}

Agradeço primeiramente a Deus pela força na superação dos obstáculos e por permitir que esse momento fosse possível.

A Prof ${ }^{a} \mathrm{Dr}^{\mathrm{a}}$ Irene Kazumi Miura, minha orientadora, meus especiais agradecimentos pela oportunidade de vivenciar esta experiência acadêmica, pela paciência em me fazer enquadrar nessa outra realidade, pelas críticas, incentivos e reconhecimentos nos momentos certos, enfim, por toda a sua participação e contribuição para a concretização deste estudo.

Ao Prof. Dr. Sérgio Takahashi, pelo envolvimento na orientação para a construção do projeto e pela inestimável contribuição para o desenvolvimento deste trabalho. Sua paixão contagiante pelo tema gestão do conhecimento foi para mim um grande incentivo.

Ao Prof. Dr. Maurício Ribeiro do Valle e à Prof. Dra. Adriana Backx Noronha Viana agradeço toda a atenção dispensada por ocasião do exame de qualificação, bem como as valiosas contribuições para o aprimoramento do projeto de dissertação.

À Prof. Dra. Geciane Silveira Porto pela atenção e auxílio para a elaboração das fundamentações metodológicas para as pesquisas desenvolvidas neste trabalho.

Ao Dr. Adelmo Emerenciano, um exemplo de profissional do conhecimento por quem tenho grande admiração, meus agradecimentos especiais por todo o apoio que viabilizou a concretização deste estudo.

Aos colegas da "posfearp", especialmente à Lesley, à Talita, à Lara e à Sheila, pela acolhida, pela amizade e pela rica troca de experiências.

À querida amiga Roseli pela amizade e pelo apoio nos momentos mais críticos desse período, o meu carinho e gratidão.

À grande amiga Eleonora, pela acolhida calorosa no período em que cursei as disciplinas na FEA SP. 
Ả minha equipe, especialmente à Bernadete, Karina, Juliana, Lilian e Lissandra pelo apoio na continuidade dos projetos na empresa, durante minhas ausências dedicadas aos estudos e pesquisas que resultaram neste trabalho.

Aos integrantes da Academia de Desenvolvimento de Competências, na qual foi aplicado o modelo conceitual de gestão do conhecimento, pelo comprometimento com os objetivos do programa, pelo tempo disponibilizado às entrevistas e depoimentos.

A todos aqueles que, direta ou indiretamente, contribuiram para o alcance deste meu objetivo. 


\section{SUMÁRIO}

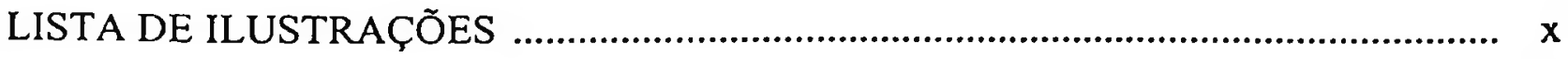

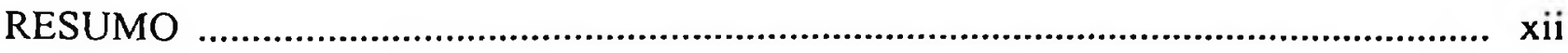



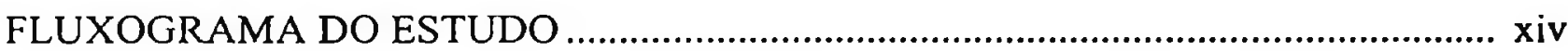

INTRODUÇÃO ................................................................................................ 1

PROBLEMA DE INVESTIGAÇÃO .......................................................................... 4

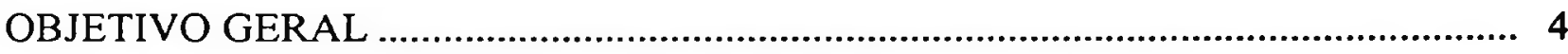

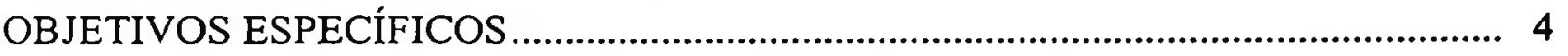

PARTE I - FUNDAMENTAÇÕES ................................................ 5

CAPÍTULO 1 - FUNDAMENTAÇÕES TEÓRICAS ...................................................6 6

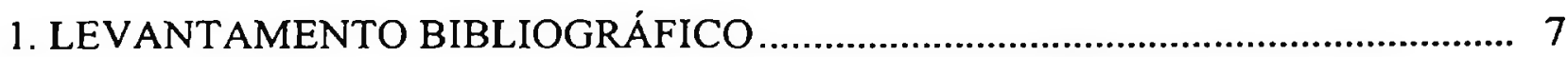

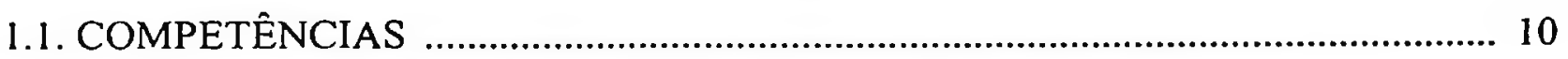

1.1.1. Competências humanas ou individuais ..................................................... 10

1.1.2. Das competências individuais às competências organizacionais................. 16

1.1.3. Identificação das competências individuais ................................................. 19

1.2. O CONHECIMENTO ORGANIZACIONAL ....................................................... 21

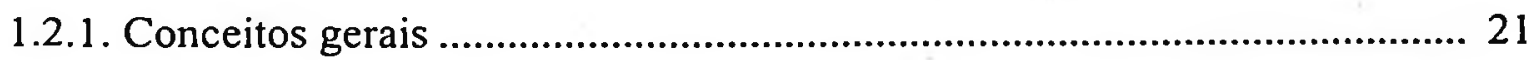

1.2.2. A gestão do conhecimento (GC) organizacional ........................................ 28

1.2.3. Contexto adequado aos processos de gestão do conhecimento (GC) .......... 31

1.2.4. A gestão do conhecimento (GC) na prática ................................................ 37

1.3. O SEGMENTO DE SERVIÇOS ............................................................................ 40

1.3.1. A prática da gestão do conhecimento nas empresas de consultoria............ 47 


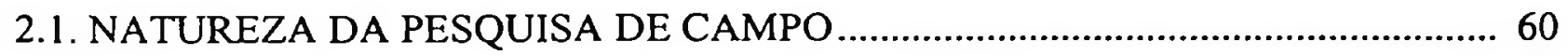

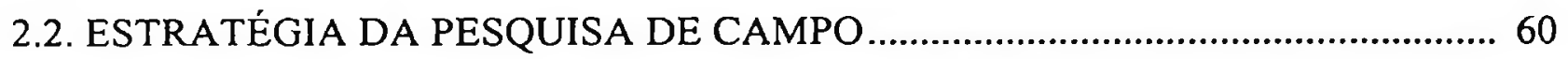

2.2.1. Justificativa da escolha do estudo de caso para a pesquisa de campo ........ 60

2.3. PROJETO DA PESQUISA DE CAMPO ................................................................ 64

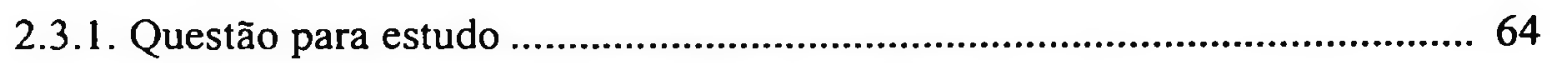

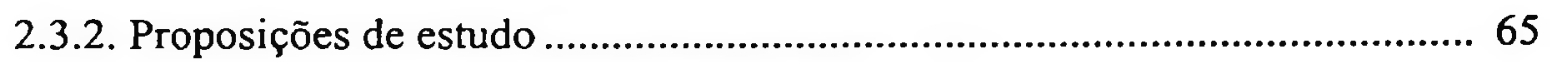

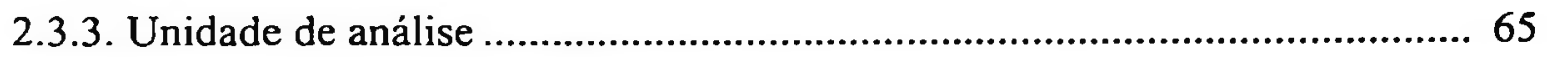

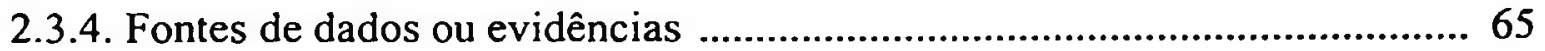

2.3.5. Lógica que une as informações às proposições ............................................ 70

2.3.6. Critérios de interpretação dos resultados ..................................................... 70

2.4. LIMITAÇÕES DA ESTRATÉGIA DE ESTUDO DE CASO …………………...... 71

2.5. PROTOCOLO PARA O ESTUDO DE CASO......................................................... 71

2.5.1. Visão geral do projeto ................................................................................. 72

2.5.2. Procedimentos de campo............................................................................ 72

2.5.3. Questões do estudo de caso.......................................................................... 73

2.5.4. Guia para o relatório do estudo de caso ...................................................... 75

PARTE II - RESULTADOS _............................................................... 76

CAPÍTULO 3 - RESULTADO DA FASE TEÓRICA _................................................. 77

3.1. ELABORAÇÃO DO MODELO CONCEITUAL DE SISTEMA DE GC ..................... 78

3.1.1. O caminho do conhecimento individual ao conhecimento organizacional. 81

3.1.2. Sistema de GC para o desenvolvimento de competências ............................ 84 
4.1. Contextualização ....................................................................................... 88

4.1.1. O segmento de assessoria e consultoria jurídica .............................. 88

4.1.2. A empresa estudada .......................................................................... 91

4.2. A construção do sistema de gestão por competências ...................................... 94

4.2.1. O padrão referencial e a situação (ideal $x$ real).................................. 96

4.3. Programa Academia de Desenvolvimento de Competências ........................ 97

4.3.1. Composição da Academia de Desenvolvimento ................................. 98

4.3.2. Etapas do programa - aplicação do modelo conceitual ..................... 100

4.4. Indicadores de desempenho do programa ADC............................................ 105

4.5. A percepção dos integrantes da ADC .......................................................... 108

4.5.1. Relatório das entrevistas com os profissionais em

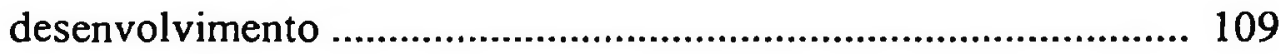

4.5.2. Relatório das entrevistas com os orientadores ................................. 114

4.5.3. Depoimentos dos demais participantes ........................................... 117

4.6. Notas da observação direta e participante........................................................ 118

\section{CAPÍTULO 5 - ANÁLISE DOS DADOS COLETADOS ............................................ 121}

5.1. Análise do contexto em que a pesquisa se desenvolve .............................. 122

5.2. Análise do processo de elaboração do padrão referencial de

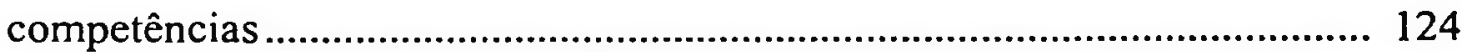

5.3. Análise do processo de identificação das defíciências das competênicas foco do programa em estudo

5.4. Análise da aplicação prática do modelo conceitual de GC para o desenvolvimento de competências............................................................ 125

5.5. Análise dos indicadores de desempenho do programa ADC …................... 134 
5.5.1. Análise dos indicadores de desempenho dos profissionais

em desenvolvimento (P1, P2 e P3) 136

5.6. Análise do desempenho do programa ADC no periodo estudado 138

CAPÍTULO 6 - CONCLUSÕES E IMPLICAÇÕES

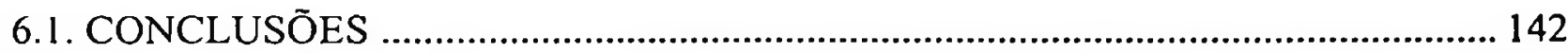

6.1.1. Sobre a experiência da aplicação do sistema de GC ................................ 142

6.1.2. Sobre o modelo conceitual de sistema de GC ........................................ 143

6.1.2.1. Sobre o núcleo ................................................................... 144

6.1.2.2. Sobre a primeira esfera..................................................... 145

6.1.2.3. Sobre a segunda esfera ..................................................... 146

6.1.2.4. Sobre a terceira esfera ........................................................... 147

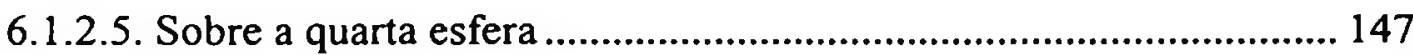

6.1.3. Sobre os reflexos da literatura no modelo............................................... 148

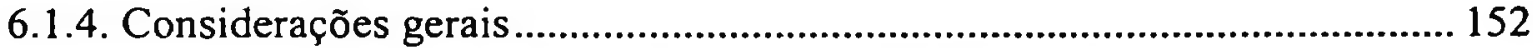

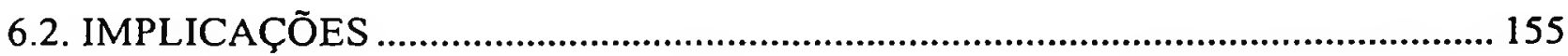

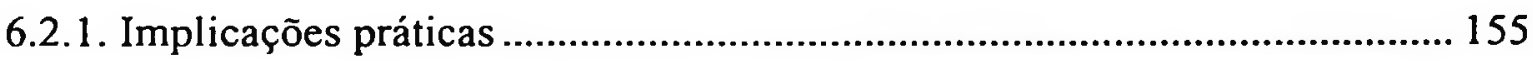

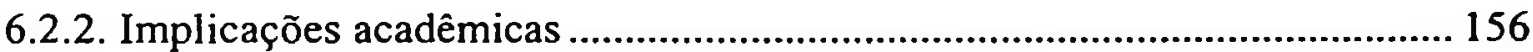

6.3. LIMITAÇÕES E RECOMENDAÇÕES PARA FUTURAS PESQUISAS............... 158

REFERÊNCIAS BIBLIOGRÁFICAS 160

\section{APÊNDICES}

APÊNDICE 1: Lógica que une as informações coletadas aos objetivos do trabalho ....... 168 APÊNDICE 2: Plano de trabalho e cronograma de execução ....................................... 170 APÊNDICE 3: Agenda das atividades de coleta de dados ..................................... 171 


\section{LISTA DE ILUSTRAÇÕES}

\section{FIGURAS}

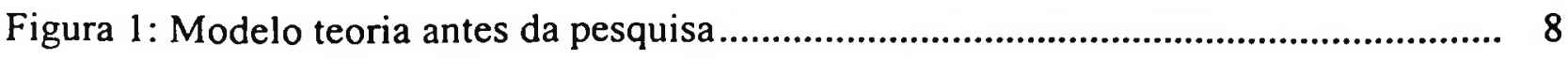

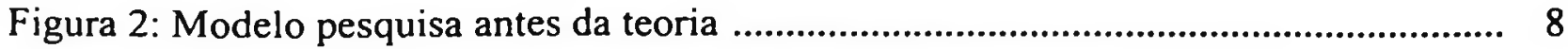

Figura 3: Abordagem espiral de modelo de pesquisa ............................................ 8

Figura 4: Plano provisório de pesquisa bibliográfica ........................................... 9

Figura 5: Relações entre a estratégia, as competências organizacionais e as individuais .. 19

Figura 6: Dimensões da criação do conhecimento................................................. 23

Figura 7: Espiral do Conhecimento ................................................................... 25

Figura 8: $\mathrm{O}$ triângulo de marketing de serviços ................................................... 42

Figura 9: Modelo hierárquico de orientação ao consumidor .......................................... 44

Figura 10: Cadeia de lucros em serviços ................................................................. 46

Figura 11: Modelo do Consultor: um corretor de tecnologia que transfere conhecimentos de negócios pelas empresas ................................................................ 48

Figura 12: Vantagem Competitiva: correntes de abordagens ....................................... 55

Figura 13: Relações entre competências e conhecimentos ...................................... 80

Figura 14: Do conhecimento individual ao conhecimento organizacional...................... 82

Figura 15: Modelo conceitual do sistema de gestão do conhecimento ........................... 85

Figura 16: Modelo representativo da estrutura organizacional da empresa estudada ....... 92

Figura 17: Ações encadeadas do sistema de GC para o desenvolvimento de competências

Figura 18: Esquema de incentivo à aplicação do conhecimento 148

\section{QUADROS}

Quadro 1: Competências do profissional

Quadro 2: Elementos da competência

Quadro 3: Síntese das abordagens sobre competências 
Quadro 4: Condições e fatores favoráveis aos processos de GC

Quadro 5: Estratégias de gestão do conhecimento

Quadro 6: Situações relevantes para diferentes estratégias de pesquisa.

Quadro 7: Questões do estudo de caso.

Quadro 8: Conjunto de saberes inerentes à competência 78

Quadro 9: Classificação das bancas de advocacia no Brasil 89

Quadro 10: Padrão referencial de competências organizacionais e individuais 95

Quadro 11: Competências organizacionais e individuais trabalhadas pela ADC 98

Quadro 12 Estrutura dos workshops 101

Quadro 13: Indicadores de desempenho do programa ADC 106

Quadro 14: Índice de evolução dos indicadores definidos para a ADC 107

Quadro 15: Resultado conjunto dos profissionais em desenvolvimento 140 


\section{RESUMO}

O novo tempo, marcado por mudanças profundas e cada vez mais freqüentes, exige das organizações decisões e respostas rápidas, aumentando a complexidade da arte de administrar negócios e impulsionando as empresas a uma mobilização na busca do desenvolvimento e criação de diferenciais que thes confiram vantagens competitivas. Nesse contexto, o conhecimento $\mathrm{e}$ as competências organizacionais despontam como principais recursos de vantagem competitiva, entre os diferenciais apontados pela mídia especializada, por estudos acadêmicos e pelas práticas gerenciais. Considerando esse cenário, o presente trabalho tem dois objetivos principais: i) elaborar um modelo conceitual de sistema de gestão do conhecimento para o desenvolvimento de competências e ii) investigar sua aplicação prática. A estruturação do modelo resulta da contribuição de diversos autores abordados no levantamento bibliográfico realizado na primeira fase do trabalho. A investigação da aplicação do modelo será realizada através de estudo de caso único em empresa brasileira do setor de serviços, atuante no segmento de assessoria e consultoria jurídica, a qual implementou o modelo em programa de desenvolvimento de competências individuais e organizacionais.

Palavras-chave: gestão por competências, gestão do conhecimento, setor de serviços. 


\begin{abstract}
The turbulent and complex environment nowadays, where changes are more and more frequent, demands quick decisions and an uncountable number of different responses from organizations, increasing the complexity of managing business. In such a highly competitive context organizations are forced to move fast to create and capture value in order to develop sustainable advantages. In this scenario, competences building and knowledge creation and management are pointed out by researches, top executives and business media as the main source to develop competitive advantages. Some authors even affirm that knowledge is the key resource of the new society. This paper focused two main objectives: i) create a conceptual model of knowledge management system to develop individual and organizational competences based on literature and ii) investigate its effectiveness through a case study in a brazilian law firm. The investigation presented positive results.
\end{abstract}

Key words: competences-based management, knowledge management, services industry. 


\section{INTRODUÇÃO}

Existe na sociedade moderna a consciência de que os avanços tecnológicos e o ambiente globalizado provocaram profundas alterações na maneira que as pessoas se relacionam com o mundo, na interação das organizações com o seu público interno e com o seu ambiente externo. Um ambiente marcado por competição acirrada, em que a concorrência está bem próxima, independente da distância fisica entre organizações. Um ambiente onde o contato entre comunidades e nações com diferentes hábitos, costumes, crenças, com outras culturas enfim, independe de tempo ou distância, em que o fluxo de informações em profusão e em tempo real invade computadores e mentes.

O novo tempo, marcado por mudanças profundas e cada vez mais freqüentes, exige das organizações alto grau de agilidade nas decisões e respostas para sobreviver no cenário altamente competitivo, aumentando a complexidade da arte de administrar negócios. Nesse contexto, as empresas são impulsionadas à mobilização na busca do desenvolvimento e da criação de recursos que lhes confiram diferenciais competitivos. Entre os diferenciais apontados por estudos e práticas gerenciais, bem como pela midia especializada, as competências organizacionais e o conhecimento despontam como principais recursos de vantagem competitiva.

O conhecimento tem sido considerado chave para o sucesso das organizações que se dão conta de que "suas possibilidades e restrições estratégicas já não estão baseadas na limitação de capital, na demanda, na capacidade de produção ou no acesso a mercados estrangeiros". No contexto atual, "as restrições se encontram na escassez de pessoas qualificadas para agregar valor para o cliente e levar a organização à economia globalizada" (SPENDER, 2001, p. 28). Tal situação se potencializa nas empresas de serviços de consultoria, cujo produto é o próprio conhecimento que, em primeira instância, pertence ao indivíduo. Drucker $(1994,2001)$ reforça essa tendência afirmando que a próxima sociedade será a sociedade do conhecimento. Uma sociedade em que o conhecimento será o recursochave e a força do trabalho será dominada pelo trabalhador do conhecimento.

$\mathrm{Na}$ prática, o conhecimento também tem recebido atenção crescente das organizações. Estudos vêm sendo desenvolvidos na tentativa de se elaborar métodos de gestão desse ativo intangivel. Alguns autores questionam o emprego do termo "gestão", que traz em si a idéia de controle, e argumentam que, não podendo ser controlado, o conhecimento não 
poderia ser gerido (VON KROGH; ICHIJO; NONAKA, 2001). Outros ainda não concordam em classificá-lo como ativo (BUKOWITZ; WILLIAMS, 1999), visto que a empresa não pode ser totalmente proprietária do conhecimento como qualquer bem material, uma vez que criálo, transmiti-lo e aplicá-lo depende em grande parte da vontade e da motivação dos individuos. $O$ conhecimento é parte integrante das competências organizacionais, que fornecem às organizações condições para sua sobrevivência e competitividade.

Sobre o tema competência, Prahalad; Hamel (1990) destacam a necessidade de se desenvolver uma arquitetura estratégica para a construção e consolidação das competências essenciais da organização. Segundo os autores, as competências essenciais se caracterizam como vantagem competitiva por proporcionarem acesso potencial a uma ampla variedade de mercados, por darem significativa contribuição à percepção do cliente sobre os benefícios do produto e por serem de dificil imitação por parte da concorrência. Os autores ressaltam a importância de se identificar a localização, a quantidade e a qualidade das pessoas que incorporam as competências essenciais, pois são elas que formarão as competências organizacionais.

Nesse sentido, verifica-se a existência de uma estreita relação de interdependência entre as competências individuais e as competências organizacionais: a organização empresta às pessoas o seu patrimônio de competências, dando-lhes condições para enfrentar situações diversas. As pessoas devolvem para a organização o seu aprendizado, dando-lhe condições de sobrevivência e desenvolvimento (DUTRA, 2001).

Embora a literatura, de forma geral, trate separadamente ambos os temas (conhecimento organizacional e competências organizacionais), a utilização de conceitos e técnicas de gestão do conhecimento para o desenvolvimento de competências encontra sustentação nas ligações entre os elementos que compõem as competências e as características atribuidas ao conhecimento.

Competências, segundo a literatura, pode ser entendida como um conjunto de saberes passiveis de aprendizado que, combinados resultam em uma ação competente. Os saberes são conhecimentos (FERREIRA, 1980), que ora se encontram no nivel tácito ora no nível explícito do indivíduo. Dessa forma as competências, sendo um conjunto de conhecimentos, poderiam ser efetivamente desenvolvidas a partir de técnicas de gestão do conhecimento. Eboli (2002) admite que com a gestão do conhecimento é possivel construir as competências capazes de proporcionar diferenciação estratégica para a empresa. 
A investigação de práticas organizacionais relacionadas ao desenvolvimento de conhecimentos, ou competências, pode trazer contribuições para o desenvolvimento $\mathrm{e}$ aperfeiçoamento de sistemas voltados para essa finalidade.

Com este estudo, pretende-se elaborar um modelo conceitual de gestão do conhecimento e investigar sua aplicação prática por meio de estudo de caso em empresa do setor de serviços jurídicos. Desta forma, busca-se obter maior familiaridade e compreensão sobre o processo de desenvolvimento de competências individuais e organizacionais pela aplicação de conceitos e técnicas de gestão do conhecimento (GC).

A realização do trabalho ocorreu em duas fases: uma fase teórica e uma fase empírica. A fase teórica envolveu o levantamento bibliográfico e a construção do modelo conceitual de gestão do conhecimento para desenvolvimento de competências. A segunda é a fase empírica constituida por um estudo de caso para a investigação da aplicação prática do referido modelo conceitual.

A apresentação do trabalho está estruturada em duas partes principais.

A primeira parte trata das fundamentações teóricas (Capitulo 1) e metodológicas (Capitulo 2).

A segunda parte apresenta dos resultados. O Capítulo 3 traz os resultados do levantamento bibliográfico - a construção do modelo conceitual de GC. O Capítulo 4 mostra os resultados da pesquisa de campo, que investiga a aplicação prática do modelo conceitual. $\mathrm{O}$ Capítulo 5 apresenta a interpretação e análise dos dados coletados, com base na literatura pesquisada. Capitulo 6 é dedicado às conclusões e implicações, além de recomendações para futuras pesquisas. Na página xiv, encontra-se a representação gráfica da estrutura do trabalho. 


\section{PROBLEMA DE INVESTIGAÇÃO}

Considerando que as competências organizacionais compõem-se de um conjunto de conhecimentos, que constituem um dos principais recursos de diferenciação e vantagem competitiva, o problema de investigação definido para este estudo é: como promover o desenvolvimento de competências individuais e organizacionais utilizando conceitos e técnicas de gestão do conhecimento?

\section{OBJETIVO GERAL}

Elaborar um modelo conceitual de sistema de gestão do conhecimento para o desenvolvimento de competências individuais e organizacionais e investigar sua aplicação prática através de estudo de caso único em empresa brasileira do setor de serviços jurídicos.

\section{OBJETIVOS ESPECÍFICOS}

i) Analisar o contexto em que a pesquisa se desenvolve.

ii) Analisar o processo de elaboração do padrão referencial de competências organizacionais e individuais, que embasa o sistema de gestão por competências.

iii) Analisar o processo de identificação das deficiências das competências, cujo desenvolvimento é o foco do programa estudado.

iv) Analisar a aplicação prática do modelo conceitual de sistema de gestão do conhecimento para o desenvolvimento de competências.

v) Definir e analisar indicadores de desempenho do programa.

vi) Analisar o desempenho do programa, comparando os períodos janeiro a outubro de 2003 (T0) e janeiro a outubro de 2004 (T1). 
PARTE 1

FUNDAMENTAÇÕES 
CAPÍtUlo 1

FUNDAMENTAÇÕES TEÓRICAS 


\section{LEVANTAMENTO BIBIOGRÁFICO}

A fase teórica do presente estudo consiste em levantamento bibliográfico que servirá a dois propósitos principais:

a) dar sustentação à construção de um modelo conceitual de gestão do conhecimento para o desenvolvimento de competências e

b) servir de parâmetro para a análise dos resultados da pesquisa de campo, realizada na fase empirica.

Segundo Martins; Pinto (2001, p. 41) o levantamento bibliográfico “é a abordagem metodológica mais adequada para a elaboração de um trabalho acadêmico". Pode ser utilizado de forma independente em uma análise teórica ou pode ainda constituir parte de uma investigação empírica, como é o caso do presente estudo.

Selltiz (1974) acrescenta que explorar o trabalho já realizado por outros é uma das maneiras mais simples de reduzir esforços em um estudo cientifico.

Para Yin (2001), a formulação de uma teoria que sustente o tema a ser estudado é essencial para o direcionamento da coleta de dados e das estratégias de análise desses dados. A teoria como parte do projeto de pesquisa, além de orientar e sustentar a fase de coleta de dados, facilita a generalização analítica dos resultados do estudo de caso.

Yin (2001) diferencia os conceitos de generalização analítica, em contraposição à generalização estatística. Estudos estatísticos são generalizáveis a populações e universos, envolvem amostragens e enumeração de freqüências. Estudos de casos são generalizáveis a proposições teóricas, isto é, seu objetivo é expandir e generalizar teorias. Na generalização analitica, utiliza-se a teoria desenvolvida na fase do projeto como modelo para se comparar o resultados obtidos na fase empírica do estudo. No presente estudo, além de modelo de comparação, o levantamento bibliográfico servirá como fundamentação para a elaboração do modelo conceitual de gestão do conhecimento.

Em relação à comparação dos resultados obtidos na pesquisa com a teoria existente, Berg (1998) faz uma combinação dos modelos lineares: a) theory-before-search (Figura 1), proposto por Nachmias; Nachmias (1992, apud BERG 1998) e b) search - before - theory (Figura 2) de Merton (1968, apud BERG 1998). 


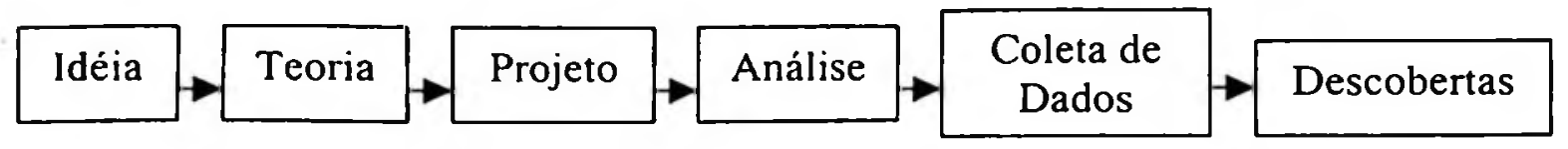

Figura 1:- Modelo teoria antes da pesquisa

Fonte: BERG, B. L. Qualitative research methods for the social sciences. Needham Heights: Allyn \& Bacon, 1998.

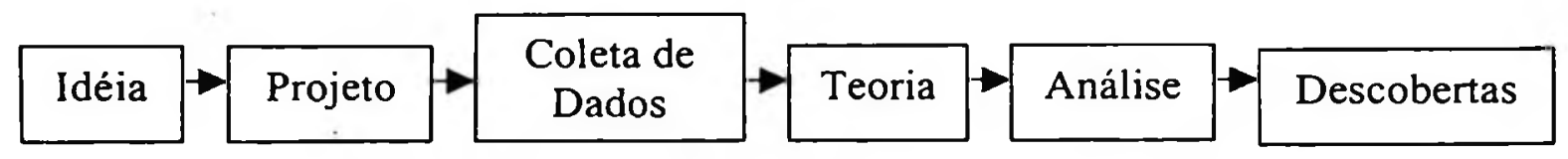

Figura 2: - Modelo pesquisa antes da teoria

Fonte: BERG, B. L. Qualitative research methods for the social sciences. Needham Heights: Allyn \& Bacon, 1998.

A partir das abordagens lineares representadas nas figuras 1 e 2, Berg (1998) propõe uma abordagem espiral que se inicia com a concepção de uma idéia. A fase seguinte seria a construção de referencial teórico, que pode redefinir a idéia inicial e assim sucessivamente. Em cada nova fase pode-se verificar a necessidade de rever e adequar a(s) fase(s) anterior(es), conforme esquema demonstrado na Figura 3.

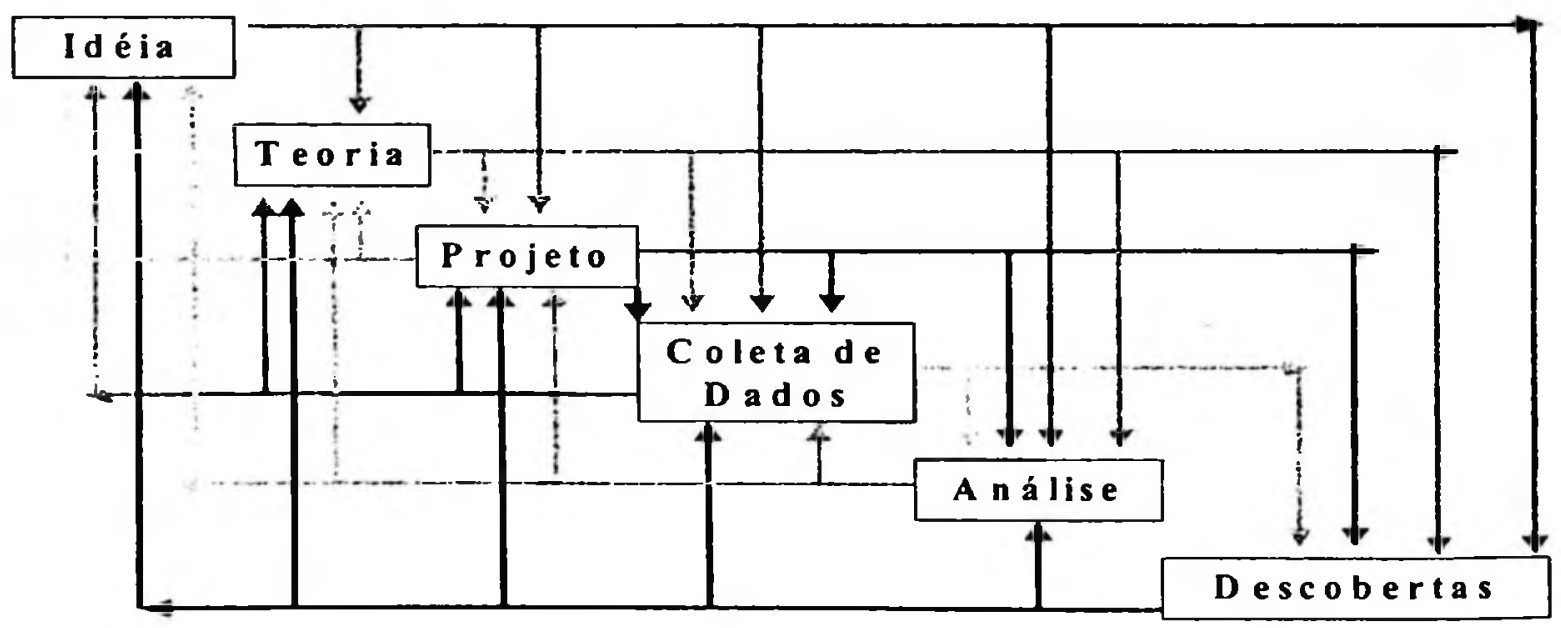

Figura 3: - Abordagem espiral de modelo de pesquisa

Fonte: BERG, B. L. Qualitative research methods for the social sciences. Needham Heights: Allyn \& Bacon, 1998. 
É com base nessa abordagem espiral que o presente trabalho se desenvolve.

A fase teórica do presente trabalho contempla etapas componentes de um levantamento bibliográfico propostas por Gil (2002), cujo início é a escolha do tema, passando pelo próprio levantamento bibliográfico, formulação do problema, elaboração do plano provisório da pesquisa, busca de fontes, leitura do material, fichamento, construção lógica do trabalho e finalizando com a redação do texto (GIL, 2002).

O levantamento bibliográfico desenvolvido neste capítulo tem como foco principal os temas "competências" e "gestão do conhecimento", que fundamentam a construção do modelo conceitual de GC para o desenvolvimento de competências. O capítulo traz também uma seção sobre vantagem competitiva, em virtude dos temas (conhecimento e competências) serem considerados como tal, e outra sobre o segmento de serviços, visto que a aplicação do modelo conceitual é realizada em empresa desse setor.

O levantamento bibliográfico fundamentou a formulação do problema de investigação exposto na introdução do presente trabalho: "como promover o desenvolvimento de competências individuais e organizacionais utilizando conceitos e técnicas de gestão do conhecimento?".

O plano provisório do levantamento bibliográfico representado pela Figura 4 foi importante para "delinear sistemicamente a estrutura lógica da fase teórica do trabalho de forma que as partes estivessem vinculadas e ordenadas para dar unidade ao conjunto", conforme coloca Salvador (1982, p.62 apud GIL, 2002, p. 69).

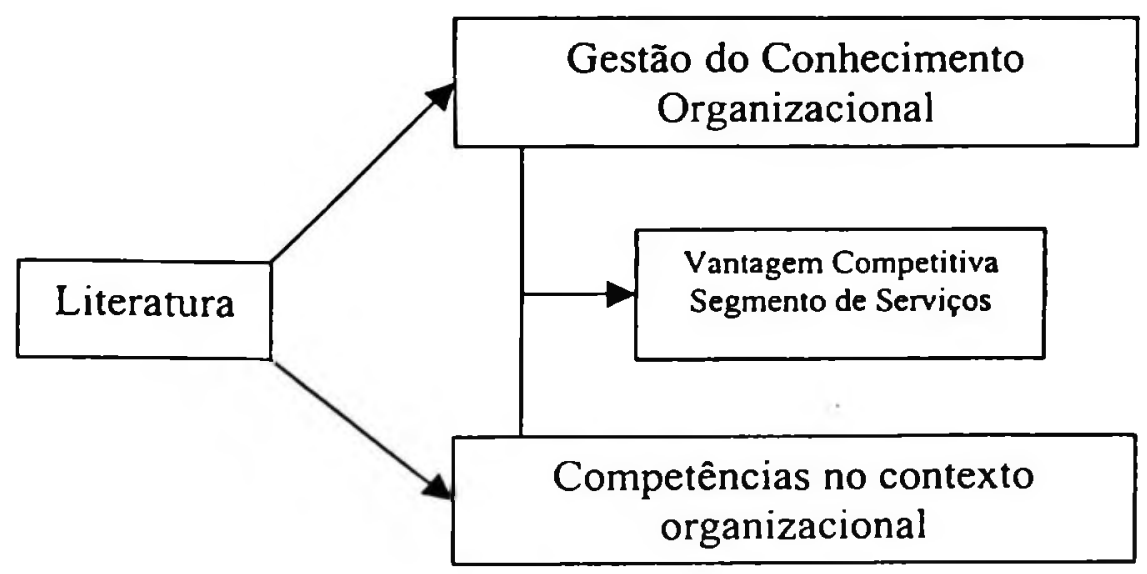

Figura 4: Plano provisório de pesquisa bibliográfica Fonte: Autora 
As fontes para a busca do material literário foram o acervo disponível na FEA-USP, em catálogos de editoras como Campus, Bookman, Gente, Atlas, Elsevier etc., no site Proquest-Information and Learning e no acervo disponibilizado pela CAPES (Coordenação de Aperfeiçoamento de Pessoal de Nível Superior). Com relação ao período, ambos os temas o conhecimento e as competências no contexto organizacional, começaram a ser explorados de forma mais significativa a partir da década de 90 , razão pela qual a pesquisa abrange o periodo 1990 a julho de 2004. Outras obras foram consideradas fora do período definido, em virtude da sua relação com o tema e relevância do seu conteúdo para o foco deste trabalho.

\subsection{COMPETÊNCIAS}

\subsubsection{Competências humanas ou individuais}

O debate sobre competências foi intensivamente fomentado por Prahalad e Hamel com a publicação do artigo The core competence of the corporation (A competência essencial da corporação), publicado em 1990 pela Harvard Business Review. Porém, segundo Fleury (2002), o tema começou a ser debatido por psicólogos e administradores norte-americanos por volta de 1973, com a publicação do artigo Testing for competence rather than inteligence (Testando por competências em vez de inteligência) de D. McClelland.

Conforme expõe Fleury (2002), McClelland define competências como caracteristicas pessoais que podem levar ao desempenho de uma performance superior. Essas características são aptidões (talento natural, passível de aprimoramento), habilidades (aplicação prática de um talento) e conhecimento (o saber necessário para realizar algo).

A partir de então, outros estudos e contribuições para a construção da definição de competências são encontrados na literatura.

Segundo Dutra $(2001,2004)$ e Fleury (2002), as competências humanas podem ser entendidas como um conjunto de conhecimentos (saber), habilidades (saber fazer) e atitudes (saber ser). Admitindo que a existência desse conjunto de características não garante que a organização se beneficie delas, os autores adicionam o conceito de entrega. Por entrega entende-se a aplicação prática das competências gerando valor para a organização. Considerar 
a capacidade de entrega das pessoas é uma maneira mais adequada de avaliá-las, orientá-las, desenvolvê-las e recompensá-las.

Medef (1998, apud ZARIFIAN, 2001, p. 66), define competência como uma combinação de conhecimentos, de saber fazer, de experiências e comportamentos que se exerce em um contexto preciso, constatada quando de sua utilização em situação profissional a partir da qual é passivel de validação (informação verbal)'. Medef adiciona que a responsabilidade de identificá-la, avaliá-la, validá-la e fazê-la evoluir cabe à organização.

Para definir competências, Zarifiam (2001) propõe uma série de abordagens.

A primeira define competência como a capacidade que um indivíduo tem de tomar iniciativa, de ir além do que está prescrito, de compreender e dominar novas situações com as quais se depara no trabalho, de assumir responsabilidade sobre elas, obtendo reconhecimento por isso. O autor afirma que essa definição dá ênfase às mudanças fundamentais na organização do trabalho, destacando a inadequação da prescrição das tarefas tendo em vista a necessidade de abertura de espaço para o individuo poder se mobilizar e exercer sua autonomia.

A segunda afirma que competência é um entendimento prático de situações que se baseia em conhecimentos adquiridos em experiências anteriores, que são transformados e ampliados à medida que aumenta a diversidade das situações. Nessa abordagem o autor coloca a dinâmica da aprendizagem como fator essencial ao desenvolvimento das competências.

$\mathrm{Na}$ terceira abordagem, destacando o conceito de co-responsabilidade, Zarifian (2001), acrescenta que a competência é a capacidade de mobilizar uma rede de autores e fazer com que eles compartilhem ações e responsabilidades em torno das mesmas situações.

A partir dessas definições, Fleury (2002, p. 55) propõe que competência consiste em "saber agir responsável e reconhecido que implica saber mobilizar, integrar, transferir conhecimentos, recursos, habilidades, que agreguem valor econômico à organização e valor social ao individuo".

\footnotetext{
' Definição fornecida por Medef nas Jornadas Internacionais de Deauville: objetivo competências, em 1998.
} 
Com base na obra de LeBoterf, Fleury (2002) destaca significados específicos contidos nessa definição, os quais encontram-se expostos no Quadro 1.

\begin{tabular}{|l|l|}
\hline Saber agir & $\begin{array}{l}\text { Saber o que e porque faz. } \\
\text { Saber julgar, escolher e decidir. }\end{array}$ \\
\hline Saber mobilizar recursos & Criar sinergia e mobilizar recursos e competências \\
\hline Saber comunicar & Compreender, processar e transmitir informações e conhecimentos \\
\hline Saber aprender & $\begin{array}{l}\text { Trabalhar o conhecimento e a experiência, rever modelos mentais e saber se } \\
\text { desenvolver. }\end{array}$ \\
\hline $\begin{array}{l}\text { Saber se engajar e se } \\
\text { comprometer }\end{array}$ & Saber empreender e assumir riscos. Comprometer-se. \\
\hline $\begin{array}{l}\text { Saber assumir } \\
\text { responsabilidades }\end{array}$ & $\begin{array}{l}\text { Ser responsável assumindo os riscos e as consequências de suas ações, sendo } \\
\text { reconhecido por isso }\end{array}$ \\
\hline Ter visão estratégica & $\begin{array}{l}\text { Conhecer e entender o negócio da organização, seu ambiente, identificando } \\
\text { oportunidades e alternativas }\end{array}$ \\
\hline
\end{tabular}

Quadro 1: Competências do profissional

Fonte: FLEURY, M. T. L. A gestão de competência e a estratégia organizacional, In: FLEURY, M. T. (coord.). As Pessoas na Organização. São Paulo: Gente, 2002.

Para Le Boterf (2003), a competência é o resultado da intersecção de três fatores: 1) a pessoa, sua biografia e socialização, 2) sua formação educacional e 3) sua experiência profissional. Uma ação competente implica em mobilizar, integrar e transferir recursos, conhecimentos e habilidades, agir com responsabilidade e ser reconhecido por isso.

Segundo o autor, a competência é uma abstração, não tem existência material e depende de uma pessoa que a concretize. Dessa forma, competência não é um estado, mas sim uma ação. Uma ação competente é o resultado da combinação de recursos pessoais (conhecimentos, habilidades, qualidades, experiências, capacidades cognitivas, recursos emocionais etc.) e recursos do meio (tecnologia, banco de dados, livros, redes de relacionamento etc.). Nos recursos do meio, o indivíduo pode buscar complementos para os seus recursos pessoais, quando não possuir todos os saberes que necessita para realizar sua ação competente. A competência do profissional consiste em saber combinar esses recursos para produzir uma ação competente. "O saber combinatório está no centro de todas as competências." (LE BOTERF, 2003, p.12). 
Le Boterf (2003) destaca ainda elementos da competência, que considera inseparáveis da personalidade do indivíduo. Esses elementos englobam um conjunto de saberes, de saber-fazer, de aptidões ou qualidades, de recursos emocionais e fisiológicos (Quadro 2).

\begin{tabular}{|c|c|}
\hline SABERES & $\begin{array}{l}\text { - Saberes teóricos } \\
\text { - Saberes do meio } \\
\text { - } \quad \text { Saberes procedimentais }\end{array}$ \\
\hline SABER-FAZER & $\begin{array}{l}\text { - Saber-fazer formal } \\
\text { - Saber-fazer empírico } \\
\text { - } \text { Saber-fazer cognitivo }\end{array}$ \\
\hline APTIDŌES E QUALIDADES & - Saber ser (competências comportamentais) \\
\hline $\begin{array}{l}\text { RECURSOS EMOCIONAIS E } \\
\text { FISIOLÓGICOS }\end{array}$ & $\begin{array}{l}\text { - Reações emocionais - saber controlar emoções } \\
\text { ou saber comportamental }\end{array}$ \\
\hline
\end{tabular}

Quadro 2: Elementos da Competência

Fonte: Autora, com base nos conceitos de competência de Le Boterf (2003)

O conjunto dos saberes abrange os saberes teóricos (necessários para compreender um fenômeno, um objeto, uma situação, uma organização ou um processo), os saberes do meio (referentes ao contexto, compreendem os saberes sobre sistemas, processos, sobre materiais e produtos, estratégias, estrutura e cultura organizacional etc.) e os saberes procedimentais (descrevem como uma ação deve ser realizada, ou seja, os procedimentos, métodos, modos operatórios adequados; envolve um conjunto de ações a serem realizadas em uma ordem estabelecida).

Nos limites do saber-fazer encontram-se: o saber-fazer formalizado (saber utilizar os saberes procedimentais), o saber-fazer empírico (oriundo da ação, compreende os aprendizados a partir da experiência prática e envolve os sentidos - visão, perspicácia, reflexos, intuição, sensibilidade etc.) e o saber-fazer cognitivo (referente a operações intelectuais necessárias à formulação, à análise e à resolução de problemas, à concepção e à realização de projetos, à tomada de decisão, à criação ou à invenção. Envolve desde operações simples como classificações, enumerações, comparações até operações mais complexas como generalizações e raciocínio analógico).

As aptidões ou qualidades, referem-se ao saber ser. Diz respeito ao que se convencionou chamar de competências comportamentais, como por exemplo, as habilidades 
de relacionamento pessoal, atitudes flexiveis, a pró-atividade etc., cada vez mais exigidas dos profissionais no contexto organizacional.

Recursos emocionais e fisiológicos referem-se ao saber controlar as reações emocionais que podem significar obstáculos e riscos ou vantagem e auxílio na solução de problemas.

Segundo Le Boterf (2003), uma pessoa se depara com uma tal multiplicidade de situaçōes no exercício de sua atividade profissional que, para atuar com competência, precisa ter atitudes semelhantes às de um navegador. Isso implica em ajustes de comandos, redefinições de percurso, redesenhos de planos e direções. Para administrar essa diversidade de situações, o autor estabelece alguns pontos cruciais.

Primeiro é preciso envolver-se com a situação, não apenas se limitar a seguir regras e procedimentos. Nas palavras de Le Boterf (2003, p. 47), "a competência é uma ação ou um conjunto de ações finalizado sobre uma utilidade, sobre uma finalidade que tem um sentido para o profissional". É necessário que os profissionais saibam agir com pertinência dentro de diferentes contextos, realizando ações que façam sentido dentro de cada contexto especifico e que tenham real efeito sobre o que se quer modificar. O autor destaca algumas condições para que isso aconteça:

- para agir com pertinência, segundo Le Boterf (2003), é preciso saber mobilizar saberes relativos a um determinado contexto. Não se trata, porém, apenas de mobilizar saberes em um contexto familiar e seguro, mas também de fazê-lo em situações de estresse ou em situações inusitadas. A competência não reside nos recursos pessoais (conhecimentos, habilidades, experiências etc.) tampouco nos recursos do meio (tecnologia, redes de relacionamentos etc.) a mobilizar. Consiste na própria mobilização desses recursos. Os recursos por si só, não significam competência, apenas aumentam ou diminuem a possibilidade da ocorrência da ação competente.

- é preciso que cada ato tenha um significado para o profissional. Para isso deve estar inserido em um contexto maior que se estende da micro-ação (apertar um parafuso) à macro-ação (construir um carro).

- é necessário também combinar saberes múltiplos e heterogêneos. Isso significa acessar um repertório e selecionar dentre uma variedade de recursos, aqueles que 
poderão ser pertinentes a um determinado contexto. É preciso ainda organizá-los e integrá-los efetivamente para a realização de uma ação competente.

- por fim, é preciso saber transpor. A transposição envolve a capacidade de adaptar as habilidades e os conhecimentos adquiridos a partir de experiências anteriores, para aplicá-los em situações novas e diversas.

McLagan (1996) descreve os conceitos de competências em dois níveis: um relacionado ao trabalho e outro relacionado a pessoas. As abordagens relacionadas ao trabalho incluem as competências para tarefa, competências de resultados e competências para entrega. As relacionadas a pessoas envolvem conhecimentos, habilidades e atitudes. A autora reúne as duas vertentes em um rótulo denominado "attribute bundle", ou conjunto de atributos que contém competências como tarefas, competências como resultados, competências como entrega e competências como conhecimentos, habilidades e atitudes.

Essa abordagem difere das dos demais autores pesquisados, pois coloca as tarefas, os resultados e a entrega no mesmo plano dos saberes. Resgatando brevemente alguns conceitos trazidos pelos autores pesquisados nesta seção, sintetizados no Quadro 3, verifica-se que há um direcionamento à compreensão de que os saberes precedem as tarefas, os resultados e a entrega em um processo seqüencial: os saberes são aplicados em uma situação (tarefas, atividades, processos) gerando um resultado, uma entrega.

\begin{tabular}{|c|c|c|}
\hline AUTORES & $\begin{array}{l}\text { SÍNTESE DAS ABORDAGENS } \\
\text { SOBRE COMPETÊNCIAS }\end{array}$ & $\begin{array}{c}\text { RESULTADOS } \\
\text { PARA A } \\
\text { ORGANIZAÇÃO }\end{array}$ \\
\hline $\begin{array}{l}\text { McClelland } \\
\text { (1973) }\end{array}$ & $\begin{array}{l}\text { Caracteristicas pessoais como aptidões (talento natural, } \\
\text { passivel de aprimoramento), habilidades (aplicação prática de } \\
\text { um talento) e conhecimento (o saber necessário para realizar } \\
\text { algo). }\end{array}$ & $\begin{array}{l}\text { Desempenho } \\
\text { performance superior. }\end{array}$ \\
\hline $\begin{array}{l}\text { Medef } \\
(1998)\end{array}$ & $\begin{array}{l}\text { Combinação de conhecimentos, de saber fazer, de experiências } \\
\text { e comportamentos que se exerce em um contexto preciso. Ela é } \\
\text { constatada quando de sua utilização em situação profissional a } \\
\text { partir da qual é passivel de validação. }\end{array}$ & $\begin{array}{l}\text { Utilização em situação } \\
\text { profissional }\end{array}$ \\
\hline $\begin{array}{l}\text { Dutra } \\
(2001,2004)\end{array}$ & Conjunto de conhecimentos, habilidades e atitudes & Entrega de valor. \\
\hline $\begin{array}{l}\text { Fleury } \\
(2002)\end{array}$ & $\begin{array}{l}\text { saber agir responsável e reconhecido que implica mobilizar, } \\
\text { integrar, transferir conhecimentos, recursos, habilidades, que } \\
\text { agregue valor econômico à organização e valor social ao } \\
\text { individuo. }\end{array}$ & $\begin{array}{l}\text { Valor econômico } \\
\text { agregado à } \\
\text { organização e valor } \\
\text { social ao individuo. }\end{array}$ \\
\hline
\end{tabular}

Quadro 3: Síntese das abordagens sobre competências (continua)

Fonte: Autora 


\begin{tabular}{|l|l|l|}
\hline \multirow{2}{*}{ AUTORES } & \multicolumn{1}{|c|}{$\begin{array}{c}\text { SINTESE DAS ABORDAGENS } \\
\text { SOBRE COMPETENCIAS }\end{array}$} & $\begin{array}{c}\text { RESULTADOS } \\
\text { PARA A } \\
\text { ORGANIZAÇÃO }\end{array}$ \\
\hline $\begin{array}{l}\text { Le Boterf } \\
(2003)\end{array}$ & $\begin{array}{l}\text { Mobilização dos recursos pessoais (conhecimentos, } \\
\text { habilidades e atitudes) e dos recursos do meio (tecnologia, } \\
\text { livros, redes de relacionamentos etc.). Saber combinatório } \\
\text { (saberes teóricos, saberes do meio, saberes procedimentais, } \\
\text { saber-fazer formal, saber-fazer empírico, saber-fazer } \\
\text { cognitivo, saber ser, saber controlar reações emocionais). }\end{array}$ & Açampetente. \\
\hline $\begin{array}{l}\text { Zarifian } \\
(2001)\end{array}$ & $\begin{array}{l}\text { Tomar iniciativa e assumir responsabilidades em situações } \\
\text { profissionais, entendendo-as de prático de situações, com o } \\
\text { apoio de conhecimentos anteriores, que são adaptados e } \\
\text { ampliados a cada nova situação. É a mobilização de atores } \\
\text { que compartilham as implicações e as responsabilidades } \\
\text { sobre uma situação. }\end{array}$ & $\begin{array}{l}\text { Utilização em } \\
\text { atividades práticas. }\end{array}$ \\
\hline
\end{tabular}

Quadro 3: Síntese das abordagens sobre competências (continuação)

Fonte: Autora

Com base em todas as contribuições dos autores pesquisados, pode-se verificar que as definições se complementam e convergem para um ponto essencial: as competências organizacionais somente se materializam através das pessoas e de suas competências. A organização deve empreender esforços na identificação e no desenvolvimento das competências individuais para a formação das competências organizacionais.

\subsubsection{Das competências individuais às competências organizacionais}

Dentro dos conceitos do taylorismo-fordismo, durante muito tempo, as referências que existiam a respeito de qualificação profissional se restringiam ao conjunto de tarefas descritas para um determinado cargo e à certificação emitida pelo sistema educacional (FLEURY, 2002). As práticas embasadas nesse conceito começaram a entrar em descompasso com a realidade das organizações, que vem sofrendo profundas mutações. Zarifian (2001) explica tais mutações a partir do conceito de três elementos que se tornaram comuns no contexto organizacional: incidentes, comunicação e serviços.

Entende-se por incidente, tudo o que ocorre de maneira total ou parcialmente imprevista ou inesperada, perturbando o desenvolvimento normal das operações planejadas para o processo produtivo. Uma encomenda repentina com prazo de execução escasso, a falta de matéria prima, desvios de qualidade são alguns exemplos de incidentes. Os profissionais 
são demandados a intervir com rapidez para a solução de eventuais problemas e ainda, se possivel, prever e evitar a ocorrência de problemas. Isso implica em mobilizar recursos o tempo todo, ultrapassando os limites impostos pela pré-definição de tarefas.

A comunicação torna-se um elemento essencial do trabalho. Um desempenho superior envolve o compartilhamento de conhecimentos, experiências e recursos. $O$ entendimento compartilhado sobre os objetivos organizacionais propicia o desenvolvimento conjunto das ações necessárias para a sua concretização.

Trabalhar significa gerar serviço. "É uma modificação no estado ou nas condições de atividade de outro ser humano ou de uma instituição" (ZARIFIAN, 2001, p. 48). A noção de serviço deve estar presente em todas as etapas dos processos organizacionais, pressupondo a existência de um destinatário interno ou externo.

De um lado, as descrições de cargo limitam as ações dos indivíduos, de outro a realidade exige multifuncionalidade, autonomia e criatividade. Em muitas situações, desaparece a figura do supervisor, para dar lugar a grupos semi-autônomos e equipes autogerenciadas. Em busca de adequação a essa nova realidade, as empresas passam a sabotar os próprios sistemas formais (DUTRA, 2001).

Como conseqüência, emerge nas organizações a necessidade de contar com as competências organizacionais como fonte de vantagem competitiva, para ampliar sua capacidade de adaptação, de inovação e para agregar valor aos seus produtos. Essa necessidade de responder rapidamente às complexidades de um ambiente em constante mutação passa a exigir dos dirigentes organizacionais uma aposta maior na capacidade de adaptação, de iniciativa, de criatividade dos indivíduos (LE BOTERF, 2003).

Para enfrentar os desafios a que estão expostas, as empresas precisam de profissionais que vão além do prescrito, que façam escolhas, que tenham iniciativa, que tomem decisões, ao invés de indivíduos limitados ao desempenho de tarefas pré-definidas em uma descrição de cargo. As empresas precisam de pessoas que saibam agir e reagir às situações, que sejam capazes de aprender e reaprender continuamente. A capacidade de aprendizagem constante é apontada como condição de sobrevivência para as organizações (SENGE, 1990). Todos esses desafios, no entanto, esbarram na fragilidade dos sistemas que se baseiam no conceito de descrição de cargos para gerenciar o desenvolvimento e o comportamento dos indivíduos (LAWLER III, 1994). 
Nesse contexto, em que as pessoas, suas habilidades e seus conhecimentos se tornam críticos para o desempenho da organização, o conceito de competências toma corpo e passa a ser visto como uma base mais adequada para os modelos de gestão de pessoas. A gestão por competências traz uma noção de mobilidade profissional, mais adaptada à realidade vivida pelas empresas nos dias atuais (LE BOTERF, 2003). O conceito de cargo, ao contrário, ajusta-se melhor às situações de estabilidade e previsibilidade, o que está longe de refletir a atual realidade das empresas.

Para Le Boterf (2003) a competência-chave de uma empresa resulta da combinação das competências e do profissionalismo dos indivíduos. Nesse sentido, Dutra (2001) descreve com propriedade a estreita relação entre as competências individuais e as organizacionais. Coloca-as em situação de interdependência em um sistema simbiótico de retro-alimentação, cujo resultado é e contribuição mútua. A organização empresta às pessoas o seu patrimônio de competências, dando-lhes condições para enfrentar situações diversas. As pessoas devolvem para a organização o seu aprendizado, dando-lhe condições de sobrevivência e desenvolvimento (Figura 5, p.19).

Também Prahalad; Hamel (1990) consideram que a empresa seja um conjunto de competências e capacidades, que ganham corpo através das habilidades humanas. Os autores chamam a atenção do mundo corporativo para a necessidade de a alta gerência se dedicar ao desenvolvimento de uma arquitetura estratégica com a finalidade de construir e consolidar as competências essenciais da organização.

As competências podem ser previstas e estruturadas de forma a permitir a criação de um conjunto de qualificações ideais para uma performance superior (DUTRA; HIPÓLITO; SILVA, 2001; DUTRA, 2000, 2004), mas poucas empresas se dão conta disso. Por um lado estudiosos e executivos reconhecem que recursos baseados no conhecimento e nas competências organizacionais representam importantes fontes de vantagem competitiva, por outro, a maior parte das empresas têm pouca ou nenhuma idéia do valor das competências que a integram (KING; FOWLER; ZEITHAML, 2002).

A estratégia organizacional é que determina quais competências serão necessárias para sua implementação (FLEURY, 2002) e, através de um processo de aprendizagem contínua, as competências organizacionais e as competências humanas se alimentam mutuamente em um círculo virtuoso. O esquema demonstrado na Figura 5 ilustra essa relação. 


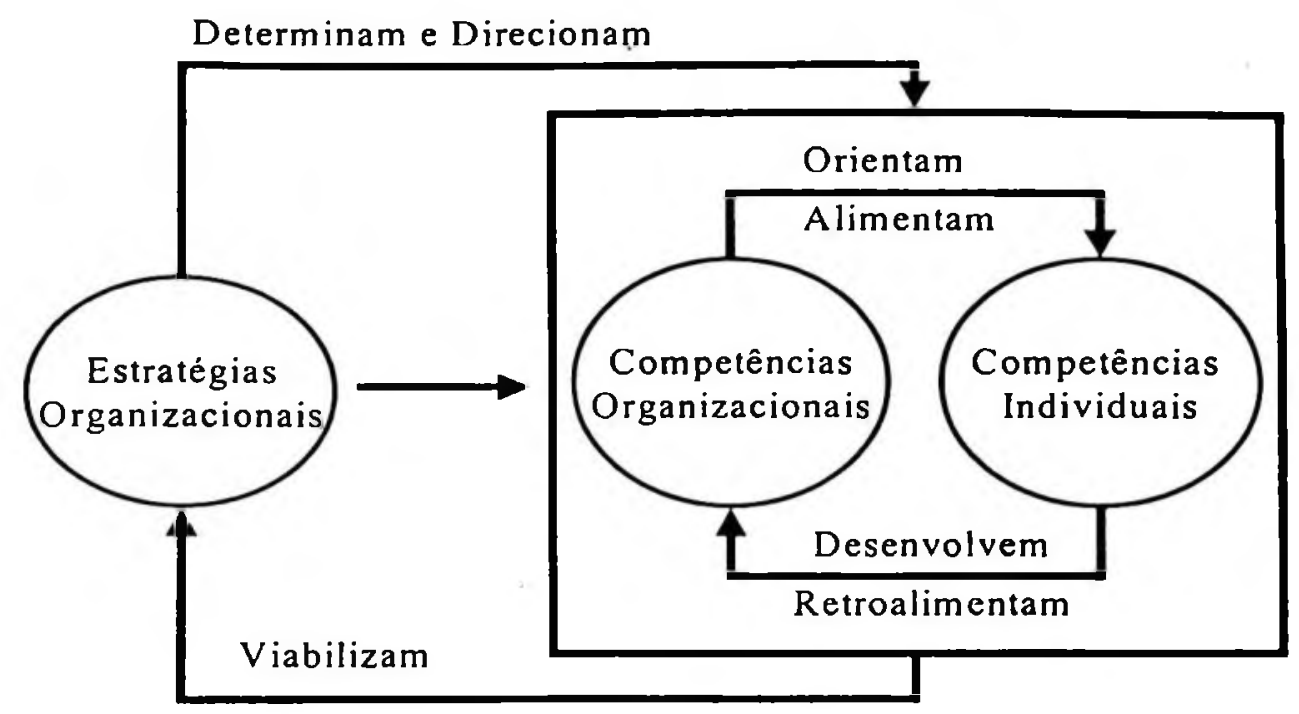

Figura 5: Relações entre estratégia, competências organizacionais e individuais.

Fonte: Autora, com base nos estudos de Zarifian (2001), Dutra (2001, 2004), Fleury (2002).

As competências individuais devem estar atreladas às competências organizacionais, que, por sua vez devem sustentar a estratégia organizacional. Para que esse alinhamento seja viável, é necessário que as organizações tenham conhecimento das competências individuais que as integram. É necessário reconhecer que identificar onde estão localizadas as competências essenciais, investigar a quantidade e a qualidade das pessoas que as incorporam são ações gerenciais de suma importância para uma organização (PRAHALAD; HAMEL, 1990). O item seguinte apresenta mecanismos para a identificação das competências individuais.

\subsubsection{Identificação das competências individuais}

Segundo Dutra, (2004), existem pelo menos três abordagens metodológicas para a identificação de competências individuais.

Na primeira abordagem, baseada nos conceitos de McClelland (1973, apud DUTRA, 2004) busca-se identificar as pessoas que apresentam performance superior, para em seguida investigar as competências que as diferenciam. Uma vez definidas, as competências 
diferenciadoras da performance superior são confrontadas com as estratégias e as competências organizacionais, consideradas essenciais e distintivas.

A segunda pressupõe uma relação natural entre os objetivos estratégicos da organização, as competências organizacionais e as competências individuais (Fleury, 2000). Essa relação existe, mesmo que a organização não seja consciente disso. Ao tomar consciência desse processo, a organização terá condições de identificar as competências individuais essenciais para o seu negócio e poderá estabelecer maior sintonia entre essas competências e seus objetivos estratégicos.

A terceira abordagem estabelece uma diferenciação entre as competências exigidas de todas as pessoas que mantém vinculo de trabalho com a organização e as competências que são exigidas de um grupo específico de profissionais. A seqüência de ações envolve primeiramente a identificação das trajetórias de carreira existentes na organização, em seguida, faz-se um levantamento das competências existentes em cada trajetória.

McLagan (1997) sugere alguns mecanismos para descrever as pessoas no trabalho que podem servir como recursos de identificação das competências individuais: análise do trabalho, entrevistas sobre incidentes críticos, conjunto de entrevistas sobre incidentes críticos, criação de pressupostos sobre o futuro e a criação de um processo de planejamento de trabalho.

Análise do trabalho: envolve a observação de pessoas de alta performance, o registro de seus resultados e do que elas fazem para obter tais resultados. O produto dessa análise é a documentação das tarefas, das entregas, dos conhecimentos, das habilidades e das atitudes demonstradas por essas pessoas.

Entrevistas sobre incidentes criticos: têm por objetivo o levantamento de situações e desafios vivenciados pelos profissionais, bem como as tarefas e as entregas envolvidas nessas situaçōes para depois inferir os conhecimentos, as habilidades e atitudes subjacentes.

Conjunto de entrevistas sobre incidentes críticos: envolve entrevistas com pessoas de performance média e com pessoas de performance superior para o levantamento das suas competências. Relacionadas as competências, eliminam-se aquelas que são comuns às duas categorias de performance. O que resta são as competências de alta performance, que deveriam receber maior atenção em processos de avaliação, desenvolvimento e promoções em um modelo de gestão por competências. 
Criação de pressupostos sobre o futuro: consiste na criação de cenários sobre o futuro do trabalho e do ambiente, com base em tendências, previsões industriais e estratégias de negócios e questionar as pessoas sobre quais as competências requeridas nos cenários desenhados.

Criação de um processo de planejamento de trabalho: trata-se de processo elaborado para guiar individuos e equipes na reflexão sobre as implicações das mudanças na estratégia e mudanças no ambiente organizacional sobre o seu próprio trabalho e sobre suas próprias competências.

Depois da identificação, o próximo passo seria a discussão sobre a melhor maneira de promover a adequação dessas competências aos objetivos estratégicos e às competências organizacionais.

\subsection{O CONHECIMENTO ORGANIZACIONAL}

\subsubsection{Conceitos gerais}

O conhecimento constitui uma questão intrincada que vem sendo vigorosamente debatida no campo da filosofia há milhares de anos, porém, em se tratando do conhecimento no âmbito das organizações, o interesse não é manter uma abordagem filosófica sobre o assunto, mas sim uma abordagem gerencial considerando os aspectos inerentes ao contexto organizacional (SPENDER, 2001). Nesse sentido, o conhecimento deve envolver o ato de conhecer revelado na solução de problemas e nas práticas produtivas de individuos e grupos na organização (p. 37).

Para Davenport; De long; Beers (1998), o conhecimento é uma combinação entre informação, experiência, contexto, interpretação e reflexão. É um recurso de alto valor, pronto para ser aplicado em ações e decisões.

Analisando a bibliografia existente sobre GC-gestão do conhecimento, Spender (2001) reconhece três diferentes abordagens. Uma delas trata o conhecimento como objeto que pode ser criado, comprado, possuido ou vendido como qualquer outro ativo organizacional. Essa perspectiva foca a dificuldade de identificação e armazenagem do conhecimento de uma empresa, dedicando pouca atenção às pessoas. Uma outra parte vem 
complementar a primeira, tratando o conhecimento como um processo de criação em nível individual e coletivo, que sofre impacto da estrutura organizacional e dos seus padrões de autoridade e controle. Essa é a abordagem que permeia o presente estudo. Há ainda uma terceira, cujo foco são os sistemas de informação.

$\dot{E}$ fato que a tecnologia da informação e os avanços nos meios de comunicação tiveram um papel essencial na gestão do conhecimento, pois uma vasta gama de informações é disponibilizada em tempo real. Mas, quando se fala em gestão do conhecimento, na prática, verifica-se uma ênfase excessiva na tecnologia da informação e recursos de mensuração. Muitas empresas acreditam contar com um sistema de gestão do conhecimento, quando apenas dispõem de um sistema depositário de informações de fácil acesso a todos. Um sistema de GC vai além da tecnologia da informação (SARVARY, 1999). É composto por vários processos de criação, de registro, de transferência ou compartilhamento e aplicação do conhecimento. Porém, só um bom sistema de GC não é garantia de sucesso.

Independente do meio de acesso (eletrônico, impresso, pessoal etc.) a informação pode ser considerada a matéria prima capaz de gerar conhecimento. Choo (2003) coloca a informação na base da organização do conhecimento, destacando três modos para sua utilização: a interpretação, a conversão e o processamento. $O$ autor descreve a organização do conhecimento como aquela capaz de realizar eficazmente a integração entre os processos de criação de significado, construção do conhecimento e tomada de decisões.

Sobre o conhecimento e sua gestão nas organizações, uma busca mais aprofundada na literatura revela que os estudos mais significativos e abrangentes foram desenvolvidos por Nonaka; Takeuchi (1997). Tomando por base empresas de cultura japonesa, esses autores desenvolveram um estudo focado na criação do conhecimento nas organizações, definindo a criação do conhecimento como a capacidade da organização de criar conhecimento, disseminá-lo em todos os níveis e aplicá-lo a produtos, serviços e sistemas, ou seja, o conjunto de processos que constituem o objeto da gestão do conhecimento. Os autores propōem uma teoria própria para a criação do conhecimento organizacional, fundamentada em outras três teorias: a teoria do conhecimento, a teoria organizacional e a teoria da inovação. Segundo Terra (2001), a tipologia do conhecimento de Nonaka; Takeuchi (1997) pode ser considerada a principal tipologia encontrada na literatura.

Para explicar o processo de criação do conhecimento, Nonaka; Takeuchi (1997) estabelecem duas dimensões: uma dimensão epistemológica e outra ontológica (Figura 6). 


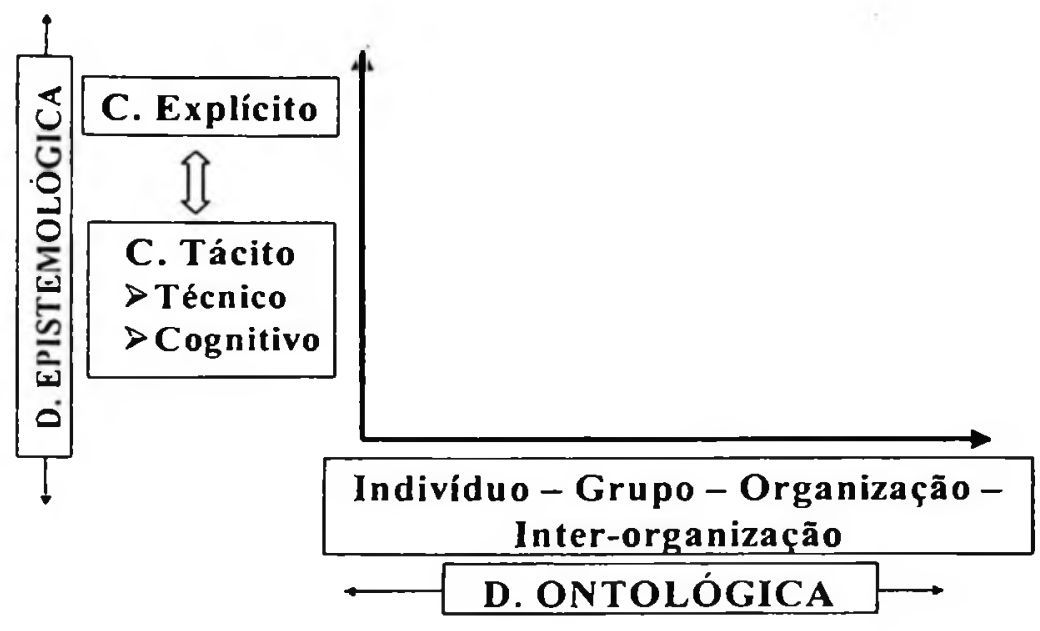

Figura 6: Dimensões da criação do conhecimento

Fonte: Adaptada de NONAKA, I.; TAKEUCHI, H. Criação do Conhecimento na Empresa, 1997.

$\mathrm{Na}$ dimensão epistemológica distinguem-se o conhecimento explícito e o conhecimento tácito. O conhecimento explícito é expresso em palavras, números, códigos, fórmulas, sendo por isso facilmente compartilhado. O conhecimento tácito, por ser de natureza subjetiva e intuitiva, é de dificil formalização e compartilhamento. O conhecimento tácito é dividido em duas sub-dimensões: a cognitiva e a técnica. A cognitiva se baseia em esquemas e modelos mentais, crenças e percepções, que moldam a forma de se ver o mundo e de se imaginar o futuro. A técnica envolve capacidades e habilidades desenvolvidas com a experiência e a prática, ou seja, o know how. Trata-se de uma visão construcionista, segundo a qual o conhecimento reside nas pessoas, muito próximo aos sentidos e experiências vividas, fazendo com que cada uma crie seu mundo de maneira única. Por essa razão, uma parte do conhecimento é altamente pessoal, de difícil expressão e compartilhamento: o conhecimento tácito. Apenas uma parte é mais facilmente codificável: o conhecimento explícito. A visão construcionista se contrapõe à visão cognitivista, segundo a qual o conhecimento é universal por consistir na representação do mundo, dos objetos e eventos que o compõem. Dessa forma dois sistemas cognitivos distintos deveriam apreender a mesma representação do mundo (VON KROGH, 1998). 
A dimensão ontológica traz o conceito de que a organização não pode criar conhecimento sem indivíduos. A criação do conhecimento começa no nível do indivíduo, estendendo-se para o grupo, posteriormente para a organização, podendo atingir níveis interorganizacionais (NONAKA; TAKEUCHI, 1997; KOGUT; ZANDER, 1992).

As teorias sobre o conhecimento organizacional foram precedidas pelas teorias sobre aprendizagem organizacional, notadamente pelos conceitos de aprendizagem organizacional de Argyris (1977). Para o autor, existem dois tipos de aprendizagem organizacional: o de circuito simples e o de circuito duplo. O aprendizado de circuito simples consiste em adquirir know how para solucionar problemas especificos com base em premissas existentes. $O$ aprendizado de circuito duplo é um método que consiste em detectar erros e problemas, questionar e reconstruir perspectivas existentes, estruturas conceituais de interpretação ou premissas decisórias. Os conceitos de aprendizagem organizacional foram retomados por Senge mais tarde, em 1990. Verificando que problemas de deficiência de aprendizado são comuns para grande parte das organizações, Senge (1990) propôs um modelo de "organização que aprende" (learning organization), que pode ser desenvolvida através da prática de cinco disciplinas: raciocínio sistêmico, domínio pessoal, modelos mentais, visão compartilhada e aprendizado em grupo.

A teoria de Senge (1990) guarda certa afinidade com a teoria da criação do conhecimento de Nonaka; Takeuchi (1997). Para Fleury; Fleury (1997), no modelo de Senge (1990) o foco inicial é o individuo e seu processo de auto-conhecimento ou autoconscientização de seus objetivos pessoais (domínio pessoal), deslocando-se para o grupo (objetivos comuns, visão compartilhada e aprendizado em grupo) e finalmente, através do raciocínio sistêmico, desloca-se para a organização e para fora dela, refletindo a idéia da dimensão ontológica de Nonaka; Takeuchi (1997), que se encontra refletida também nos estudos de Hoerem; von Krogh; Ross (1996).

Por outro lado, as teorias sobre aprendizado organizacional raramente citam o conhecimento, tampouco discorrem sobre as maneiras pelas quais o conhecimento pode ser criado. Essas teorias apresentam ainda limitações características da maioria das teorias do aprendizado organizacional, como a falta da visão de que o desenvolvimento do conhecimento se constitui aprendizado, o fato de se prenderem ao conceito behaviorista de estímulo-resposta e de não terem desenvolvido uma visão ampla sobre o aprendizado organizacional, restringindo-se à metáfora do conhecimento individual (WEICK, 1991; DODGSON, 1993 apud NONAKA; TAKEUCHI, 1997). 
Para Nonaka; Takeuchi (1997), as teorias do aprendizado organizacional permanecem presas a um consenso de que o aprendizado organizacional é um processo de mudança influenciado por experiências passadas, suportado pela memória organizacional e com foco no desenvolvimento ou na modificação de rotinas. Essa idéia se reflete no conceito do aprendizado de circuito duplo, de Argyris (1977). Na teoria da criação do conhecimento detectar erros e problemas, questionar e reconstruir perspectivas existentes, estruturas conceituais de interpretação ou premissas decisórias, não constituem tarefa complexa ou especial, é um processo que deve fazer parte da rotina da organização (NONAKA; TAKEUCHI, 1997).

Para que a criação ocorra deve haver a interação entre o conhecimento tácito e explícito. Essa interação é a principal dinâmica da criação do conhecimento organizacional (NONAKA; TAKEUCHI, 1997).

Os autores apresentam o processo de criação do conhecimento organizacional no Modelo de Conversão do Conhecimento, composto por quatro modos: a socialização, a externalização, a combinação e a internalização (Figura 7).

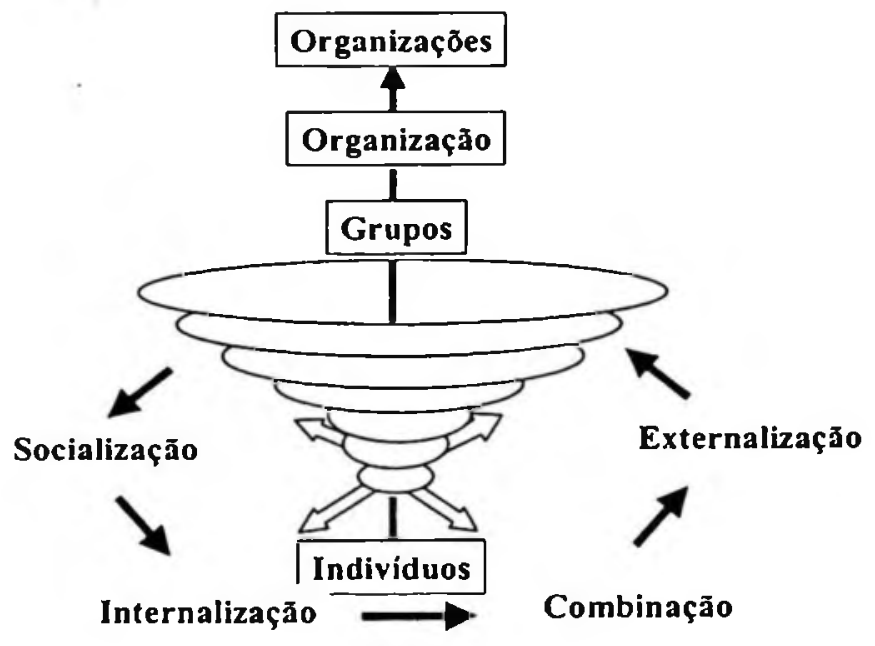

Figura. 7 - Espiral do Conhecimento

Fonte: Adaptada de NONAKA, I.; TAKEUCHI, H. Criação do Conhecimento na Empresa, 1997.

Da interação entre os quatro modos de conversão do conhecimento surge a espiral do conhecimento. 
A socialização é a conversão do conhecimento do nível tácito de um indivíduo para o nivel tácito de outro, que ocorre através de experiências compartilhadas. Sem o compartilhamento é extremamente dificil um indivíduo se projetar na forma de raciocínio de outro. Não se trata de um aprendizado através da linguagem, mas pela observação, imitação e prática como no caso de mestres e aprendizes.

Pela externalização, o conhecimento tácito é convertido em conhecimento explícito. Isso ocorre através da expressão do conhecimento por metáforas e analogias, que muitas vezes são ineficientes para reproduzir com fidelidade o conhecimento tácito, provocando diálogo e reflexão coletiva, que são as bases da externalização.

A combinação é a passagem do conhecimento do nível explícito de um indivíduo para o nível explícito de outro. É a troca de conhecimentos codificáveis, que pode se dar através de documentos, aulas expositivas, reuniões, comunicações por telefone, internet etc.

Através da internalização, ou da conversão do conhecimento explícito em tácito, o conhecimento explícito é incorporado às bases de conhecimento tácito do individuo, sob a influência do seu modelo mental.

A criação se inicia no nível do indivíduo e, através da interação entre a socialização, combinação, internalização e externalização (dimensão epistemológica), atinge gradativamente os grupos (equipes, setores, áreas), a organização, podendo ocorrer em âmbito inter-organizacional (dimensão ontológica). A espiral do conhecimento representada na Figura 7 (p.25) é a base da teoria da criação do conhecimento.

Uma vez que a organização não produz conhecimento por si, ela depende dos conhecimentos tácitos dos indivíduos que a integram. Esses conhecimentos, quando compartilhados transformam-se na base da criação do conhecimento organizacional através da socialização.

O processo de criação do conhecimento organizacional, segundo Nonaka; Takeuchi (1997), passa por cinco fases: o compartilhamento do conhecimento tácito, a criação de conceitos, a justificação desses conceitos, a construção de um arquétipo e a difusão interativa do conhecimento.

Uma organização sozinha não cria conhecimento. Para isso depende do conhecimento tácito dos individuos, que não é facilmente comunicado ou transmitido através de palavras. O compartilhamento do conhecimento tácito fica mais fácil por meio do 
compartilhamento de modelos mentais, experiências, emoções e sentimentos. Esse compartilhamento é crucial para o processo de criação do conhecimento organizacional.

Na criação de conceitos, o modelo mental tácito compartilhado na primeira fase é expresso em palavras, números, códigos e conseqüentemente cristalizados na forma de conhecimento explícito, através da externalização.

A justificação de conceitos envolve o processo de avaliar se os conceitos recémcriados são interessantes para a organização e a sociedade.

$\mathrm{Na}$ seqüência ocorre a construção de um arquétipo. Nesta fase o conceito justificado é transformado em algo concreto, tangível, como por exemplo, um protótipo no caso de desenvolvimento de um novo produto.

A quinta e última fase é a difusão interativa do conhecimento. Esta é a fase em que o novo conceito criado, depois de justificado e materializado, é difundido para os diversos niveis da organização na dimensão ontológica da criação do conhecimento.

Com um foco mais direcionado à criatividade e inovação, para Leonard-Barton; Swap (1999), o processo criativo ocorre em cinco fases. A primeira é a preparação, considerando que a criatividade só brota quando o "solo mental" estiver muito bem preparado. Deve então ocorrer a oportunidade de inovação. Existem pessoas que trabalham diretamente na atividade de criar, pessoas cujo trabalho é a criatividade, mas a grande maioria não está focada na inovação. Precisam de oportunidades para criar. Essas oportunidades acontecem na forma de uma ameaça, que requer resposta imediata para garantir a sobrevivência ou na forma de um problema a ser resolvido. Na terceira fase ocorre a geração de opções ou divergências, pois é preciso gerar várias idéias, pressupondo que soluções criativas são geralmente selecionadas a partir de um conjunto de alternativas. Segue-se então a fase da incubação, o tempo em que se tira o foco da preocupação com um problema, mas o subconsciente continua trabalhando na busca de melhores soluções. Por fim, ocorre a seleção de opções ou convergência. Após a geração de várias idéias é necessário optar pela mais adequada.

Com base em ampla revisão literária, Terra (2001) verificou que há consenso de que os processos de aprendizado e criatividade são indissociáveis dos aspectos emotivos e dependentes da motivação intrínseca, são dependentes de contatos entre pessoas, de experiências concretas e beneficiam-se de diferentes inputs e perspectivas. Os processos de criação do conhecimento ou aprendizagem antecedem a atividade criativa. São processos 
intimamente conectados. A compreensão desse fato é de suma importância para a elaboração de sistemas de gestão do conhecimento organizacional.

\subsubsection{A gestão do conhecimento (GC) organizacional}

Von Krogh; Ichijo; Nonaka (2001), em continuação aos estudos desenvolvidos por Nonaka e Takeuchi (1997), admitem que o termo "gestão" seria inadequado por implicar em controle de processos que talvez sejam incontroláveis, os autores optam pela utilização da expressão "capacitação para o conhecimento". Porém, o termo "gerir" não seria de todo inapropriado, pois envolve outros significados que vão além do controle, como o planejamento, a organização e a avaliação (FLEURY, 1997).

Sarvary (1999) descreve a gestão do conhecimento como um processo através do qual a empresa cria e utiliza o conhecimento institucional ou coletivo. Esse processo é composto por três sub-processos:

- aprendizado organizacional: processo pelo qual a empresa adquire informações e conhecimentos;

- produção do conhecimento: processo que transforma e integra a informação em conhecimento útil para a solução de problemas e

- distribuição do conhecimento: o processo que permite aos demais membros da organização o acesso e a utilização do conhecimento coletivo.

A gestão do conhecimento envolve ações de estímulo à criação do conhecimento, ao seu compartilhamento, ou disseminação por todos os níveis da organização e à aplicação do conhecimento na solução de problemas e na inovação de produtos. Essas ações de estímulo correspondem a práticas gerenciais adequadas e organizadas em um sistema de gestão criado para facilitar concretização da espiral do conhecimento de Nonaka; Takeuchi (1997) representada na Figura 7 (p.25). Os autores destacam duas atribuições gerenciais essenciais para a gestão do conhecimento: a primeira consiste em identificar o potencial de conhecimento existente na organização e transformá-lo em ações geradoras de valor. A segunda implica em criar ativos intangíveis, como o conhecimento, e explorá-los de maneira mais eficaz que a concorrência, gerando diferencial competitivo. 
Nesse sentido, Terra (2001) propõe a prática de ações gerenciais, as quais podem ser verificadas em termos de planos e dimensões. Segundo o autor, a gestão do conhecimento pode ser explicada por meio de sete dimensões da prática gerencial:

i) a definição do campo do conhecimento para o qual os esforços de aprendizado devem ser direcionados;

ii) o desenvolvimento de uma cultura organizacional que favoreça a inovação, a experimentação e o aprendizado contínuo, que fomente a otimização de todas as áreas da organização e que seja orientada para longo prazo;

iii) criação de estruturas baseadas em trabalho de equipes, multidisciplinaridade e autonomia, que contribuam para a eliminação de barreiras que dificultam o aprendizado, a geração do conhecimento e a inovação;

iv) políticas e práticas de recursos humanos associadas aos processos de criação do conhecimento organizacional;

v) estímulo ao contato pessoal e criação de ambiente de confiança, transparência e colaboração e reconhecimento de que os recursos tecnológicos de comunicação e informação dependem dos indivíduos para prover resultados;

vi) mensuração dos resultados sob várias perspectivas e divulgação por toda a organização e

vii) cuidados com o relacionamento com o ambiente, com os clientes e com outras empresas.

Barclay; Murray (1997, apud BARROSO; GOMES, 1999) descrevem a gestão do conhecimento como atividades de negócios que focam basicamente dois aspectos. $O$ primeiro envolve o tratamento explícito do conhecimento envolvido nas atividades de negócios como um fator do negócio refletido em todos os niveis da empresa pela estratégia, políticas e práticas organizacionais. O segundo é o estabelecimento de uma ligação direta entre as bases intelectuais explícitas e tácitas e os resultados obtidos.

As cinco disciplinas propostas por Senge (1990) para desenvolver uma organização que aprende (domínio pessoal, modelos mentais, visões compartilhadas, aprendizado em grupo e visão sistêmica) também implicam em práticas gerenciais para viabilizar o desenvolvimento do conhecimento. Embora a teoria foque somente $o$ aprendizado 
organizacional, a prática das cinco disciplinas se assemelham às práticas sugeridas na teoria do conhecimento organizacional, conforme pontuado por Fleury; Fleury (1997).

Senge (1990) reconhece-se o indivíduo como o ponto inicial do aprendizado organizacional. Através do domínio pessoal, ele aprende a concentrar esforços no autoconhecimento, na percepção mais objetiva da realidade e no que realmente lhe importa.

Os modelos mentais são conceitos arraigados que moldam a maneira das pessoas verem o mundo, influenciando seus comportamentos e atitudes. Para se trabalhar o modelo mental, deve-se voltar para o interior e trazer à superficie os paradigmas e imagens internas, expondo-os a um exame rigoroso. Devem-se promover conversas em que as pessoas exponham suas idéias e estejam abertas às idéias de seus interlocutores. $O$ trabalho com modelos mentais pode ser apoiado pela disciplina do aprendizado em grupo. O modelo mental compartilhado pode ainda se traduzir na cultura organizacional, influenciando $o$ comportamento dos grupos na organização. A valorização da diversidade se reflete nesta disciplina.

Objetivos comuns ou visões compartilhadas implicam em buscar imagens do futuro que se deseja e utilizá-las para promover o engajamento. A existência de um objetivo comum, concreto e legítimo motiva as pessoas a darem tudo de si para aprender, não por obrigação, mas por livre e espontânea vontade. Esse conceito assemelha-se ao de visão instilada do conhecimento de Von Krogh; Ichijo; Nonaka (2001).

Uma organização só será capaz desenvolver o seu conhecimento, se as pessoas e os grupos forem capazes de aprender. O aprendizado em grupo ocorre através de diálogos e raciocinio em grupo. Isso nos remete ao conceito de gerenciamento de conversas de Von Krogh; Ichijo; Nonaka (2001).

Os trabalhos realizados pelo homem fazem parte de um sistema, em que suas ações se inter-relacionam, exercendo efeitos umas sobre as outras. O raciocínio sistêmico é a disciplina que integra as outras quatro e precisa delas para se completar. As cinco disciplinas se fundem em um conjunto coerente de teoria e prática, trazendo a idéia de que o todo é maior que a soma das partes. Para Senge (1990), a prática gerencial dessas cinco disciplinas proporcionaria as condições essenciais para o aprendizado e inovação nas organizações.

Admitindo ser dificil exercer atividades de controle sobre o conhecimento, as atividades da gestão do conhecimento devem envolver práticas gerenciais voltadas à criação de programas que favoreçam os processos de criação, transferência, compartilhamento, 
disseminação e aplicação do conhecimento na organização. A gestão do conhecimento deve contemplar a criação de contextos adequados envolvendo ambientes, estruturas, políticas, e sistemas apropriados. Deve fomentar o cultivo de valores e o desenvolvimento de uma cultura organizacional do conhecimento. A criação do contexto adequado é condição essencial para que os processos do conhecimento se efetivem, conforme argumentam Nonaka; Takeuchi (1997), Leonard-Barton; Swap (1999), Perez-Bustamente (1999), Von Krogh; Ichijo; Nonaka (2001) e Wang; Ahmed (2003).

\subsubsection{Contexto adequado aos processos de gestão do conhecimento}

O conteúdo da literatura explorada evidenciou vários fatores que compõem o contexto adequado, considerado essencial para que os processos do conhecimento ocorram de maneira efetiva. Tais fatores serão discutidos a seguir.

Von Krogh; Ichijo; Nonaka (2001) enfatizam a necessidade de se criar um ambiente propício à criação do conhecimento, baseado na "solicitude". Segundo os autores, a solicitude pode ser desmembrada em dimensões comportamentais identificadas como confiança mútua, necessária para estabelecer uma ambiente de compartilhamento, empatia ativa, que possibilita a avaliação e compreensão das verdadeiras necessidades alheias, acesso à ajuda, a ajuda deve estar ao alcance de quem a procura, como um apoio real e tangivel, leniência de julgamento, ao julgar as ações ou comportamento do outro, deve-se levar em consideração o contexto e as condições em que elas ocorreram, e coragem para manifestar opiniões, para aceitar idéias melhores que as próprias e para dar feedbacks.

É consenso entre vários autores que conceder autonomia aumenta a possibilidade de motivação dos individuos, estimula a expressão de opiniões e o compartilhamento de conhecimentos em um ambiente de liberdade. Indivíduos autônomos tendem a gerar mais idéias originais que se difundem no grupo transformando-se em idéias organizacionais. A concessão de autonomia está associada a estimulos a riscos, desapego a normas rigidas e tolerância a erros. (NONAKA; TAKEUCHI, 1997; PEREZ-BUSTAMENTE, 1999; WANG; AHMED, 2003).

As empresas também devem ter nivel adequado de informalidade e promover relações baseadas em confiança e não em controles, conforme argumentam Wang; Ahmed (2003). As relações baseadas em confiança dependem de um ambiente transparente em que 
todos conheçam com clareza a visão e as estratégias organizacionais, onde haja comunicação sem barreiras, para que as idéias possam fluir livremente em benefício de toda a organização.

Wang; Ahmed (2003) sugerem também que as organizações devem promover relações emocionais de inclusão, o que permite que os indivíduos tomem os valores organizacionais como seus. A sinergia de emoções positivas estimula a contribuição criativa em toda parte e favorecem a diversidade. Os autores propõem também o estímulo de relações interativas externamente orientadas. A interação externa reflete a abertura da organização que vai além das suas fronteiras promovendo o compartilhamento de conhecimentos facilitando o fluxo de informações interna e externamente, ao invés de se guiar por normas e procedimentos, agendas e rotinas internas permanecendo confinadas dentro dos seus próprios limites, protegendo seus conhecimentos e evitando compartilhamentos.

Perez-Bustamente (1999) destaca a importância da utilização da diversidade interna para gerenciar adequadamente as mudanças do ambiente e o fomento de uma cultura que anseia por assimilar conhecimentos externos, para combiná-los com as experiências e pensamentos internos, evitando a acomodação que impede o processo criativo, lembrando a idéia da variedade de requisitos de Nonaka; Takeuchi (1997).

Leonard-Barton; Swap (1999) acrescentam que o processo criativo sofre forte influência da cultura organizacional, a qual pode promover um ambiente físico e um clima psicológico propício à criação, ou um clima hostil ao processo criativo. Destacam também a importância do ambiente físico - layout, móveis e decoração, cores e iluminação etc. - como estímulos sensoriais à atividade criativa.

Wang; Ahmed (2003) desenvolveram estudos focando a estrutura organizacional para organizações baseadas em conhecimento. Partiram das três dimensões definidas por Schein (1988, apud WANG; AHMED, 2003) - dimensão hierárquica, dimensão funcional e dimensão de inclusão e centralização. Colocam a estrutura informal como uma quarta dimensão adicionada às três anteriormente mencionadas, pois acreditam que há uma energia escondida que flui por traz da estrutura formal. Consideram, porém, que as quatro dimensões juntas não são suficientes para fornecer a resposta requerida pela moderna transformação estrutural, no entanto, auxiliam na reflexão sobre a estrutura organizacional em um nível mais elevado, caracterizado por estruturas baseadas no conhecimento, relações interativas externamente orientadas e relações emocionais de inclusão. 
Para Wang; Ahmed (2003) as empresas devem ter estrutura horizontal composta basicamente pela alta gerência, grupos estratégicos e times de projetos, sem barreiras que dificultem o cruzamento de funções entre os times (cross-functional teams). A necessidade de haver estruturas organizacionais capazes de fomentar relacionamentos sólidos e colaboração eficaz é reforçada por Von Krogh; Ichijo; Nonaka (2001).

Para sustentar os processos do conhecimento organizacional, refletidos na espiral do conhecimento, Nonaka; Takeuchi (1997) sugerem uma combinação entre a burocracia e a força-tarefa, a qual os autores denominam estrutura hipertexto. A burocracia, por ser mais normatizada, é mais adequada para a combinação e internalização, e a força-tarefa, que envolve maior grau de autonomia, é mais adequada à socialização e externalização. Nas palavras dos autores, "a primeira é uma estrutura mais apropriada à exploração e ao acúmulo de conhecimento, enquanto a última é eficaz no compartilhamento e criação do conhecimento" (p.188).

Perez-Bustamente (1999) destaca ainda a necessidade de uma infra-estrutura de comunicação que suporte e estimule a transferência de idéias, sem limitar o potencial criativo. Também para Nonaka; Takeuchi (1997), o compartilhamento da visão, das metas e dos objetivos, requer um sistema de comunicação transparente, claro e objetivo.

Perez-Bustamente (1999) e Von Krogh; Ichijo; Nonaka (2001) destacam a necessidade do conhecimento fazer parte do referencial estratégico da organização, de maneira a direcionar os indivíduos sobre quais conhecimentos deverão desenvolver. Em outras palavras, as pessoas devem se apropriar da aspiração organizacional em termos de concretização de metas e objetivos, incorporando sua visão de futuro. Devem ter um conceito ou uma visão clara do conhecimento a ser desenvolvido para estimular o compromisso com o desenvolvimento desse conhecimento e sua operacionalização. A visão compartilhada do conhecimento propicia para os envolvidos no processo, um mapa mental de três áreas correlatas: a) do mundo em que vivem, b) do mundo em que devem viver e c) o conhecimento que devem buscar e criar.

A necessidade de políticas de valorização da diversidade é reconhecida por Nonaka; Takeuchi (1997), que defendem que a variedade de requisitos, ou seja, a diversidade interna de uma organização, a torna mais capaz de responder às ameaças da complexidade imposta pelo ambiente externo (ASHBY, 1956, apud NONAKA; TAKEUCHI, 1997). LeonardBarton; Swap (1999) acrescentam que a criação em grupo ocorre por meio da abrasão criativa. Trata-se de um processo que se estabelece a partir das diferenças (cultural, social, 
demográfica, formação, estilos de pensamento etc.) entre os integrantes do grupo que, para criar, devem desafiar-se mutuamente e ao mesmo tempo aceitar e aproveitar as diferenças intelectuais e cognitivas dos demais. A heterogeneidade cognitiva, ou, os modelos mentais combinados favorecem o surgimento de um caleidoscópio de idéias, de várias opções criativas (divergência) para que pelo menos uma possa ser desenvolvida (convergência). Essa idéia também se reflete nos conceitos de gerenciamento de conversas de Von Krogh; Ichijo; Nonaka (2001) e de aprendizado em grupo de Senge (1990). Wang; Ahmed (2003) também propõem que as estruturas baseadas no conhecimento requerem equilíbrio entre a diversidade (contribuições múltiplas) e a unidade (análise das diversas contribuições para uma performance única).

Uma outra forma de fomentar a criação é a flutuação, intervenção sugerida por Nonaka; Takeuchi (1997), que envolve uma interferência no estado de ser habitual e confortável, um colapso de hábitos e estruturas cognitivas que provocam um caos. Isso aumenta a tensão no ambiente e direciona a atenção dos indivíduos para a definição do problema e para a solução da situação de crise. A flutuação pode ser provocada por situações contextuais ou pode ser provocada intencionalmente pela alta gerência da organização induzindo o caos criativo. O processo de indução intencional da flutuação deve ser bem gerenciado, pois, se houver perda do controle da situação, o caos provocado pode ser destrutivo ao invés de criativo.

Outra prática gerencial sugerida por vários autores é a superposição (redundância) intencional de informações sobre as atividades, sobre responsabilidades, sobre a empresa como um todo. Há várias formas de se desenvolver a redundância na organização, um exemplo é a criação de diferentes grupos para desenvolver um mesmo projeto para posteriormente comparar as diferentes propostas para uma escolha mais adequada. Outra forma seria a divisão de atividades e responsabilidades difusas entre equipes, de maneira que os indivíduos invadam mutuamente suas fronteiras funcionais precipitando o aprendizado por intrusão. A permissão e estímulo à duplicidade de programas de pesquisas provocando a sobreposição de informações e atividades, incrementa a comunicação de idéias e o compartilhamento de conhecimento tácito. Para Nonaka; Takeuchi (1997), a redundância dissemina o conhecimento explicito pela organização e ocorre principalmente através do compartilhamento de idéias e experiências. Para que isso ocorra, é necessário que haja um ambiente, no qual as pessoas se sintam apoiadas e desafiadas, mas não ameaçadas (NONAKA; TAKEUCHI, 1997; PEREZ-BUSTAMENTE 1999). 
Outra prática para estimular a geração do conhecimento é a criação de situações gerenciadas que permitam a troca pessoal de informações entre os integrantes do grupo, que Von Krogh; Ichijo; Nonaka (2001) denominam gerenciamento de conversas. Através do gerenciamento de conversas, amplia-se o conhecimento tácito pelo compartilhamento com outras pessoas na organização. Criando condições para a ocorrência da abrasão criativa, proposta por Leonard-Barton; Swap (1999), é possível gerenciar a produção do conhecimento imprescindivel para a inovação. Tais ações também favorecem o aprendizado em grupo proposto na teoria de Senge (1990).

Von Krogh; Ichijo; Nonaka (2001), defendem também a idéia da mobilização de ativistas do conhecimento, considerados atores importantes no processo criativo, sendo fundamentais para a criação do conhecimento. São as pessoas responsáveis pela energização e integração dos esforços de criação de conhecimento na empresa. Por fím, a prática da disseminação do conhecimento por todos os níveis, é o que garante a construção do conhecimento organizacional.

Para facilitar a compreensão e análise, os fatores favorecedores dos processos do conhecimento organizacional identificados na literatura explorada serão a seguir classificados em termos de: i) ambientes e relações, ii) estrutura e iii) estratégias, ações gerenciais e politicas organizacionais (Quadro 4).

\section{AMBIENTES E RELAÇÕES}

- Ambiente de solicitude: confiança, empatia, leniência ao julgar, acesso à ajuda e coragem.

- Nivel adequado de informalidade

- Ambiente de liberdade

- Nivel adequado de transparência

- Clima psicológico propício à criação.

- Relações interativas externamente orientadas (abertura para o compartilhamento de conhecimentos)

- Relações emocionais de inclusão

- Ambiente fisico com estímulos sensoriais

Quadro 4: Condições e fatores favoráveis aos processos de GC (continua)

Fonte: Autora 


\section{ESTRUTURAS}

- Estrutura tipo hipertexto: combinando burocracia e força-tarefa.

- Estruturas horizontais, com poucos níveis hierárquicos.

- Ausência de barreiras departamentais.

- Estruturas baseadas na confiança (não em controle).

- Infra-estrutura de comunicação que suporte e facilite o fluxo de informações e idéias ESTRATÉGIAS, AÇÕES GERENCIAIS E POLÍTICAS

- Disseminação de informações: comunicação clara da visão de futuro, dos objetivos, das estratégias e do conhecimento necessário para a implementação das estratégias e alcance dos objetivos organizacionais.

- Compartilhamento de valores, objetivos, visão de futuro, estratégias e conhecimento organizacional.

- Estímulo ao domínio pessoal.

- Estimulo ao risco e tolerância a erros.

- Promoção da redundância de informações.

- Criação de normas e procedimentos com adequada flexibilidade.

- Concessão de autonomia em nível adequado.

- Promoção da livre fluência de idéias em todos os níveis da organização.

- Promoção do aprendizado em grupo.

- Promoção de ambientes e situações de criação e compartilhamento (de idéias, conhecimentos e experiências).

- Gerenciamento de conversas.

- Promoção e estímulo do raciocínio sistêmico.

- Identificação e mobilização dos ativistas do conhecimento nos processos de criação do conhecimento organizacional.

- Promoção da flutuação e caos criativo.

- Respeito, valorização e aproveitamento das idéias diferentes.

- Promoção da combinação de modelos mentais, valorização da diversidade e da heterogeneidade cognitiva.

- Estímulo a divergências e promoção de convergências: promoção da abrasão criativa.

- Promoção da disseminação do conhecimento em todos os níveis da organização: globalização do conhecimento local.

- Promoção e valorização da variedade interna para enfrentar a complexidade externa.

- Criação de políticas e sistemas adequados aos processos de criação do conhecimento.

Quadro 4: Condições e fatores favoráveis aos processos de GC (continuação)

Fonte: Autora 
Os sistemas organizacionais operacionalizados pelas práticas gerenciais devem estar direcionados para viabilizar tais condições, facilitando e fomentando a criação do conhecimento e a sua integração às competências organizacionais, de maneira a constituir efetivamente uma vantagem competitiva para a organização.

A seguir serão apresentadas algumas situações que exemplificam a prática da gestão do conhecimento organizacional.

\subsubsection{A gestão do conhecimento na prática}

Davenport; De Long; Beers (1998) pesquisaram projetos de gestão do conhecimento em vinte e quatro empresas de diferentes segmentos. Identificaram basicamente quatro tipos classificados segundo seus objetivos: a criação de depósitos de conhecimento, ampliação do acesso ao conhecimento, intensificação do ambiente do conhecimento e gerenciamento do conhecimento como um ativo.

Os projetos focados na criação de depósitos de conhecimentos tratavam o conhecimento como uma coisa, um objeto, uma entidade separada das pessoas que o criaram e utilizaram. A intenção era reunir documentos que contivessem algum tipo de conhecimento (memorandos, relatórios, apresentações), organizá-los em um depósito de onde pudessem ser facilmente recuperados.

Quando os projetos focavam a ampliação do acesso ao conhecimento, procuravam facilitar a transferência do conhecimento entre individuos. Nesses casos, havia o reconhecimento de que encontrar pessoas com determinados conhecimentos e providenciar sua transferência para outras pessoas é um processo muito difícil.

O terceiro tipo de projeto, que focava a intensificação do ambiente do conhecimento, tinha como objetivo estabelecer um ambiente efetivamente propício à criação, à transferência e à utilização do conhecimento. Nesses casos, verificaram-se ações de conscientização, de adequação da cultura organizacional, iniciativas para mudar comportamentos em relação ao conhecimento e tentativas de aprimorar o processo de gestão do conhecimento. 
Um quarto tipo de foco tratava o conhecimento como um ativo, como qualquer outro em seu balanço patrimonial. Um dos exemplos mais marcantes desse tipo de projeto é o caso da Skandia, grande empresa sueca do ramo de serviços financeiros, que inclui seu capital intelectual em seus balanços e demonstrações financeiras (DAVENPORT, DE LONG; BEERS, 1998).

Para identificar características associadas a sucesso ou insucesso, Davenport; De Long; Beer (1998), utilizaram quatro indicadores: i) crescimento dos recursos investidos no projeto (incluindo dinheiro, pessoas etc.), ii) crescimento no volume de conhecimento armazenado, no volume de acesso e utilização, iii) a probabilidade de o projeto sobreviver sem a(s) pessoa(s) responsável(is) por ele e iv) qualquer evidência de retorno financeiro ligado às atividades de gestão do conhecimento - este último indicador não precisaria ser rigorosamente especificado, a percepção do retorno já seria uma evidência.

Os autores verificaram que cada tipo de projeto apresentava, além do seu objetivo foco, aspectos pertencentes aos demais tipos. Notaram também que os projetos considerados de sucesso apresentavam alguns fatores em comum:

- relações com a performance econômica ou valor industrial, como por exemplo o caso em que a empresa aumentou suas receitas provenientes de licenças de patentes e propriedade intelectual, ou o caso de empresa que ampliou os conhecimentos sobre os clientes, criou uma base de conhecimento online, reduzindo o custo de telefonia envolvido nas ligações de suporte a cliente. Outro exemplo é o caso de empresas de consultoria, como a Ernest \& Young, que mensuram a contribuição do conhecimento armazenado em seus depósitos para 0 fechamento de novas vendas.

- infra-estrutura tecnológica e infra-estrutura organizacional, os autores argumentam que contar com uma infra-estrutura tecnológica orientada para 0 conhecimento, como por exemplo o Lotus Notes ou uma rede mundial (World Wide Web-based), aumenta a probabilidade de sucesso do projeto. O mesmo ocorre se a empresa contar com infra-estrutura orgnizacional envolvendo estrutura de papéis, grupos de profissionais com as habilidades requeridas para as atividades de gestão do conhecimento, editores, facilitadores, incluindo a existência de uma gerência para o projeto ( $C K O$ - corporate knowledge officer). 
- estrutura flexível e padronizada, a padronização se faz necessária para que a compreensão do sistema seja geral, nesse sentido, a criação de categorias e termos-chave auxilia a eficácia do acesso pelos usuários. $O$ conhecimento, por ser um elemento intrincado e estreitamente ligado ao ser humano, apresenta mudanças freqüentes em termos de categorias e significados. A flexibilidade da infra-estrutura permite ao sistema acompanhar essas mudanças mantendo a consistência.

- cultura favorável ao conhecimento - é um dos fatores mais importantes para o sucesso do projeto e ao mesmo tempo, o mais difícil de se criar, se ele ainda não existir. As pessoas costumam relutar em compartilhar seus conhecimentos por acreditarem que é o valor que as mantém como profissionais, por instinto de sobrevivência no emprego. A cultura orientada para o conhecimento é aquela que valoriza o aprendizado dentro e fora do ambiente do trabalho, é uma cultura em que a experiência, as competências e as especialidades se sobrepõem à hierarquia.

- clareza de linguagem e propósitos - são aspectos que facilitam o compartilhamento do significado pelas pessoas, minimizam a ocorrência de interpretações errôneas e entendimentos distorcidos.

- mudanças nas práticas motivacionais - por ser intrinsecamente ligado às pessoas, seus egos e posições, o conhecimento não emerge ou flui naturalmente através dos papéis e limites funcionais. Motivar para a criação, compartilhamento e utilização do conhecimento é fator crucial para o sucesso dos projetos. Renovar as fontes de estímulo motivacional é sempre um desafio para os gestores do conhecimento.

- múltiplos canais de transferência de conhecimento - projetos considerados de sucesso promovem a transferência do conhecimento por meio de vários canais, reconhecendo que cada canal agrega valores de formas diferentes e a sinergia entre eles amplia a probabilidade de utilização. Nesta era marcada pelos avanços tecnológicos verifica-se uma tendência de valorizar os sistemas globais de comunicação eletrônica, mas é preciso atentar para a importância dos encontros presenciais, dos debates face-à-face para a criação e a transferência do conhecimento. 
- suporte da gerência sênior - o engajamento da alta cúpula é importante para que o processo tenha caráter organizacional e não seja percebido como uma iniciativa isolada de uma pessoa ou grupo. O suporte da gerência do projeto é crucial para os esforços de criação, compartilhamento do conhecimento e para sua utilização no aprimoramento de processos, produtos e resultados. Esse suporte envolve o envio de mensagens e sinais de que o aprendizado e o conhecimento são imprescindíveis para o sucesso organizacional, a provisão de fundos e outros recursos de infra-estrutura e esclarecimentos sobre quais conhecimentos são importantes para a organização.

O estudo de caso objeto do presente trabalho envolve o desenvolvimento de competências orientadas para clientes, em empresa do segmento de serviços. Por essa razão, a seção seguinte trará uma breve contextualização desse segmento, principalmente no que se refere à administração de marketing e de recursos humanos.

\subsection{O SEGMENTO DE SERVIÇOS}

Há autores que julgam desnecessário distinguir se uma empresa produz bens ou serviços, bastaria classificar tais produtos como tangiveis ou intangíveis (LEVITT, 1981 apud LOURES, 2003).

Para outros estudiosos existem algumas características que diferenciam o segmento de serviços da indústria de produção de bens, como é o caso de Zeithaml; Parasuraman; Berry (1985) Kother (2000) e Zeithaml; Bitner (2003). Para esses autores, as características consideradas específicas do segmento de serviços e amplamente citadas na literatura são:

- a intangibilidade - os serviços não têm existência física e não podem ser vistos ou tocados da mesma maneira que os produtos;

- a perecibilidade - os serviços não podem ser estocados para venda ou uso posterior;

- a heterogeneidade - a qualidade e essência de um serviço podem variar de provedor para provedor, de cliente para cliente, e de dia para dia e 
- a inseparabilidade entre a produção e o consumo - os serviços, diferentemente dos bens são produzidos e consumidos ao mesmo tempo.

A função de serviços, segundo Kandampully (2002), interage com quase todas as atividades e elementos relacionados à empresa. Isso inclui pessoas, processos, evidências fisicas que representem a empresa sob a perspectiva do cliente (sejam elas tangiveis ou intangíveis), clientes internos e externos, redes de relacionamento, alianças e parcerias. $O$ autor destaca as redes de relacionamento externas como recursos de grande importância, pois através delas, a empresa pode obter a capacidade e o conhecimento necessário para satisfazer as necessidades de seus clientes de forma ampla e diferenciada.

Do ponto de vista de marketing e de recursos humanos, a importância do comportamento humano se potencializa nas empresas de serviços, em virtude das peculiaridades que envolvem a produção e comercialização de serviços e em comparação com a produção de bens. Tais peculiaridades se constituem em desafios exclusivos e diferenças na complexidade que envolve a administração de empresas desse segmento (ZEITHAML; BITNER, 2003.). Os autores argumentam que os executores de serviços estão presentes no momento em que os serviços são produzidos e consumidos, interagindo diretamente com os clientes. São partes integrantes do produto e ingredientes essenciais da percepção do consumidor em relação ao serviço. Nesse sentido, podem contribuir para a ampliação da qualidade e satisfação, ou ainda, prejudicar a execução do serviço e a percepção do cliente. Dessa forma, uma força de trabalho competente e motivada constitui fator crítico de sucesso para as empresas do segmento de serviços.

Vários estudos evidenciam que a simpatia, o entusiasmo, a segurança, a atenção do prestador de serviços e a confiança que ele inspira afetam positivamente a percepção do cliente em relação à qualidade do serviço. Clientes ficam mais satisfeitos quando o funcionário possui a habilidade, o desejo e a competência para resolver seus problemas (PRICE; ARNOULD; TIERNEY, 1995; HARTLINE; FERREL 1996).

Na literatura de serviços existem modelos e ferramentas de auxílio aos gestores na análise dos desafios inerentes à gestão das organizações desse segmento e na condução de estratégias especificas de marketing e de recursos humanos. Entre as citadas, encontra-se o triângulo do marketing de serviços (Figura 8), um esquema conceitual que aponta para os agentes essenciais na construção e manutenção das relações com os clientes (ZEITHAML; BITNER, 2003). 


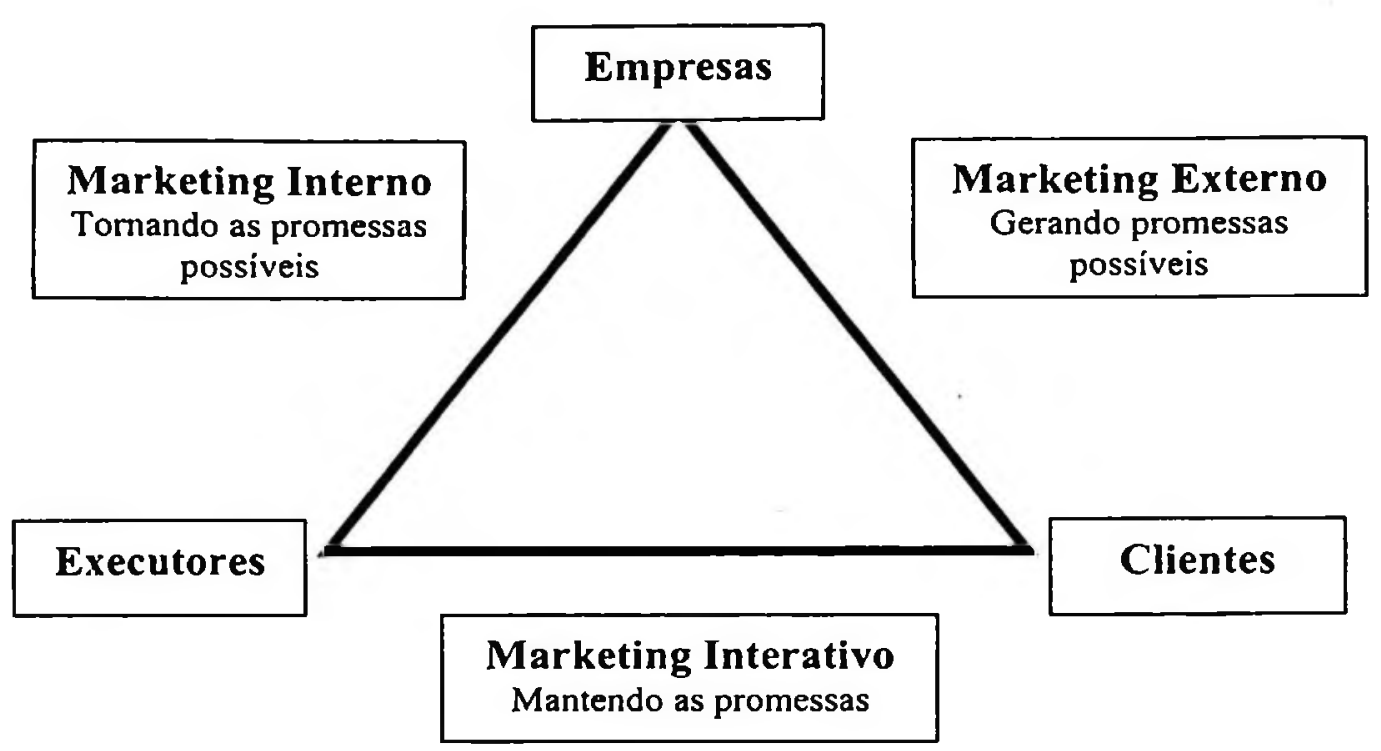

Figura 8 - $\mathrm{O}$ triângulo de marketing de serviços.

Fonte: ZEITHAML, V. A.; BITNER, M. J. Marketing de Serviços: a empresa com foco no cliente. Porto Alegre: Bookman, 2003; KOTLER, P.; ARMSTRONG, G. Introdução ao Marketing. Rio de Janeiro: LTC, 2000

O triângulo, apresentado na Figura 8, mostra os três grupos inter-relacionados que trabalham juntos para o desenvolvimento, a promoção e a execução dos serviços. Os seguintes agentes centrais estão dispostos nas pontas do triângulo: a empresa, os clientes e os executores. Entre os três vértices do triângulo, existem três tipos de relações que devem ser conduzidas com sucesso, para que o serviço possa ser bem executado - marketing externo, marketing interativo e marketing interno.

As atividades de marketing externo consistem nas ações por meio das quais a organização gera promessas a seus clientes, levando em consideração suas expectativas e os meios de atendê-las. As atividades de publicidade, vendas, promoções e precificação contribuem para a geração de promessas aos clientes. No setor de serviços, existem ainda outros fatores que colaboram para comunicar a promessa da empresa aos clientes. Os funcionários, o projeto, a decoração e o próprio processo, de acordo com Zeithaml; Bitner (2003), participam da comunicação e da geração de expectativas nos clientes.

A manutenção das promessas feitas aos clientes, ou seja, o marketing interativo, ocorre no "momento da verdade", quando o cliente interage com a organização e o serviço é 
produzido e consumido. Essa atividade é a mais importante, do ponto de vista do cliente. As promessas dos serviços são mantidas ou frustradas pelos funcionários da organização em tempo real.

Finalmente, para que as promessas feitas aos clientes possam ser mantidas, o executor dos serviços - aquele que efetivamente faz o serviço chegar ao cliente - deve ter as habilidades, competências, ferramentas e motivação para executá-las. Ou seja, devem ser capacitados para tal. Essa atividade é normalmente conhecida como marketing interno. $\mathrm{O}$ marketing interno é baseado na premissa de que a satisfação do funcionário e a satisfação do cliente estão profundamente vinculadas uma à outra.

Pelo exposto até o momento, não é difícil perceber que no setor de serviços as três atividades de marketing são essenciais para o sucesso de uma organização. Sem um dos lados, o triângulo, ou todo o esforço de orientação para o cliente, fica sem apoio. O funcionário desempenha um papel fundamental na manutenção desse equilíbrio e atua como elo de ligaçāo entre os três lados do triângulo.

Segundo Zeithaml; Bitner (2003), no segmento de serviços os trabalhadores muitas vezes desempenham papéis de marketing, ainda que não tenham consciência disso. Eles são o principal canal de comunicação entre a empresa e o cliente, isto é, desenvolvem uma função fundamental ouvindo e interpretando informações, intermediando a entrada e saída de recursos da organização.

A capacidade de um funcionário de adaptar-se às diferentes necessidades e desejos específicos também afeta positivamente a percepção do cliente, aumentando sua confiança no serviço.

A adaptabilidade pode ser definida como uma habilidade dos funcionários de ajustar seu comportamento às demandas inter-pessoais durante o contato com o cliente. Pesquisas demonstram que a performance de um vendedor está positivamente relacionada com a prática de adaptação durante a venda e também com a percepção do cliente durante o contato com o funcionário (HARTLINE; FERREL,1996).

A performance do prestador de serviços, por sua vez, pode ser afetada pelo seu nivel de motivação e por aspectos de sua personalidade. Brown et alii (2002) desenvolveram um modelo hierárquico dos efeitos da personalidade no comportamento. 
De acordo com esse modelo, os traços básicos da personalidade, combinados com un contexto específico em que o trabalhador de serviços desempenha o seu papel, produzem traços superficiais de personalidade ou disposições, inclinações ou tendências de comportamento nesse contexto. É o comportamento resultante dessa combinação que alimenta a percepção do consumidor (Figura 9).

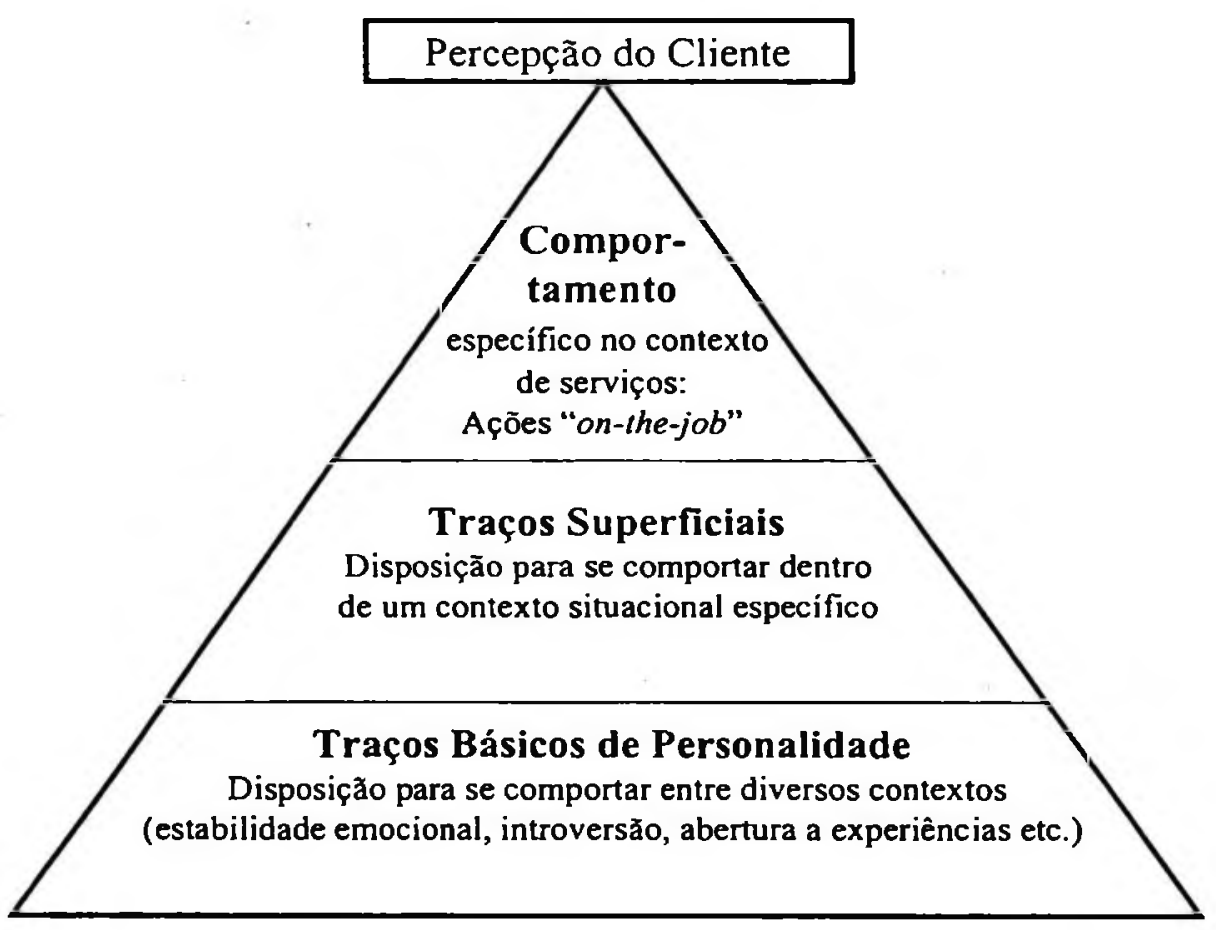

Figura 9: Modelo hierárquico de orientação ao consumidor

Fonte: Autora, com base no modelo proposto por Brown et alii (2002)

No contexto de serviços, em razão da impossibilidade de se separar o momento da produção do momento da venda e do consumo, é alto o grau de interatividade entre produção e marketing, entre marketing e cliente, entre produção e cliente. O mesmo funcionário pode desempenhar o papel de profissional de produção, profissional de marketing e profissional de vendas. Dessa forma, o trabalho dos profissionais de serviços exige muito mais que habilidades fisicas, intelectuais e mentais, demandando grande trabalho emocional.

Estudos de Price; Amould; Tierney (1995) demonstram que o trabalho emocional do prestador é major ainda em encontros de serviços mais duradouros, como os caracterizados pelos serviços de consultoria e assessoria jurídica, objeto desse estudo. $O$ executor deve ser 
cortês, cordial, mostrar interesse, independente dos seus problemas pessoais, dos seus sentimentos interiores.

Além disso, conforme argumentam Zeithaml; Bitner (2003), o profissional de serviços desempenha um papel estressante, pois se depara constantemente com situações que se constituem em fontes de conflitos como aqueles existentes entre os interesses do cliente e os da organização que representa, conflitos de decisões entre qualidade e produtividade e conflitos entre clientes nas situações em que o prestador de serviços atende um cliente na presença de outros.

Considerando que as personalidades e os comportamentos humanos são heterogêneos, diferentes funcionários podem prestar o mesmo serviço de formas variadas, ou ainda, uma mesma pessoa pode prestar o mesmo serviço com diferentes níveis de qualidade e consistência dependendo do tipo de cliente, do seu estado emocional e de outras variáveis que interferem na sua interação com o cliente. Essas variações causam problemas de consistência e qualidade do serviço.

A qualidade percebida em serviços, componente da satisfação de clientes, é uma avaliação focada que reflete a percepção do cliente sobre dimensões específicas dos serviços. Essas dimensões incluem confiabilidade - habilidade do provedor executar o serviço prometido de modo seguro e preciso; responsividade - vontade de ajudar os cliente e de prestar serviços sem demora; segurança - conhecimento do executor aliado a sua habilidade para inspirar credibilidade e confiança; empatia - cuidado, atenção individualizada dedicada aos clientes; e itens tangíveis - aparência pessoal, aparência das instalações físicas, equipamento, e materiais impressos (ZEITHAML; BITNER, 2003).

Novamente, o desempenho do prestador de serviços vai interferir diretamente na percepção do cliente, uma vez que todas as dimensões da avaliação de qualidade realizada pela cliente se traduzem em comportamento humano. Dependendo de seu estado emocional ou grau de motivação e segurança, o funcionário pode executar ou não o serviço conforme tenha sido prometido, pode traduzir ou não as suas competências em resultados de valor agregado, pode responder ou não as expectativas de atendimento, ter ou não vontade pessoal de ajudar o cliente, dedicar ou não atenção em ouvir e compreender o que o cliente quer e precisa.

Zeithaml; Bitner (2003) argumentam que funcionários satisfeitos tendem a apresentar alta performance, gerando clientes satisfeitos e clientes satisfeitos podem reforçar o 
sentimento de satisfação dos funcionários, motivando-os a buscar melhoria contínua no desempenho de suas atividades. Acrescentam ainda que existem fortes ligações entre o nível de qualidade dos serviços internos, a satisfação, a lealdade e a produtividade dos trabalhadores, o valor dos serviços prestados aos clientes, a fidelização dos clientes e os lucros da organização como demonstra a Figura 10.



Figura 10: Cadeia de lucros em serviços

Fonte: Adaptada de ZEITHAML, V. A.; BITNER, M. J. Marketing de Serviços: a empresa com foco no cliente. Porto Alegre: Bookman, 2003

Como dito anteriormente, em virtude da intangibilidade, o sentimento e a percepção do consumidor dependerá em alto grau da performance do executor do serviço. Essa dependência cresce à medida que aumenta o grau de intangibilidade do serviço, tornando se crítica para os casos em que os funcionários são o próprio serviço, como consultores, médicos, advogados, psicólogos, que configuram o maior grau de intangibilidade.

Exemplificando, uma empresa de serviços de transporte aéreo conta com uma parte tangivel que é a aeronave, os acentos, o alimento que serve a bordo. O grau de intangibilidade é diferente em uma empresa de consultoria, em que o consultor e seus conhecimentos são o próprio serviço. Este é o caso da empresa em que se insere a unidade de análise da pesquisa de campo. 


\subsubsection{A prática da gestão do conhecimento nas empresas de consultoria}

Quando se começou a olhar para o conhecimento organizacional como um recurso a ser gerenciado, as empresas de consultoria foram as primeiras a dar maior atenção ao fato, investindo significativamente e explorando agressivamente o uso da tecnologia da informação na construção de sistemas de gestão do conhecimento. Isso porque o conhecimento é a essência do seu negócio (HANSEN, NOHRIA, TIERNEY, 1999).

Para Siegel (2003) as empresas de consultoria que alcançam o sucesso apresentam quatro pontos comuns. O conhecimento (como capital intelectual único), figura em primeiro lugar, seguido pelo processo (a maneira como o conhecimento é aplicado). Em terceiro figuram as equipes (lideranças, especialistas e generalistas, seus talentos e produtividade). Em quarto lugar estão os serviços diferenciados que oferecem com criatividade e inovação.

Sobre as empresas do segmento de serviços de consultoria, Sarvary (1999) coloca que seu propósito era oferecer profissionais de alto nível, com MBA (master in business administration) nas mais renomadas escolas de negócios, capazes de resolver os problemas dos clientes. Com o tempo, os clientes passaram a contratar diretamente esse tipo de profissional. Agora, em vez de profissionais capazes de resolver seus problemas, os clientes buscam se beneficiar do manancial de conhecimentos das firmas de consultoria, adquirido pela experiência em ampla diversidade de situações nos diversos clientes para as quais prestou e presta serviços.

Sarvary (1999) define as empresas de consultoria como corretores de tecnologia e conhecimento. Através da prestação de serviços a vários clientes dos mais variados segmentos, seus profissionais vivenciam uma ampla variedade de situações (Figura 11).

De sua posição central os consultores entram em contato com uma variedade de problemas e uma vasta gama de soluções. Mesmo que esses problemas e soluções sejam diferentes em cada cliente, a experiência vivenciada promove o desenvolvimento de conhecimentos e habilidades que poderão ser utilizados em outras situações. Ainda que cada cliente seja diferente, com sua cultura própria, requerendo soluções personalizadas, o conhecimento adquirido pode ser adaptado por meio de um processo de combinações e analogias que Sarvary (1999) chama de conexões analógicas e Le Boterf (2003) denomina saberes combinatórios. 


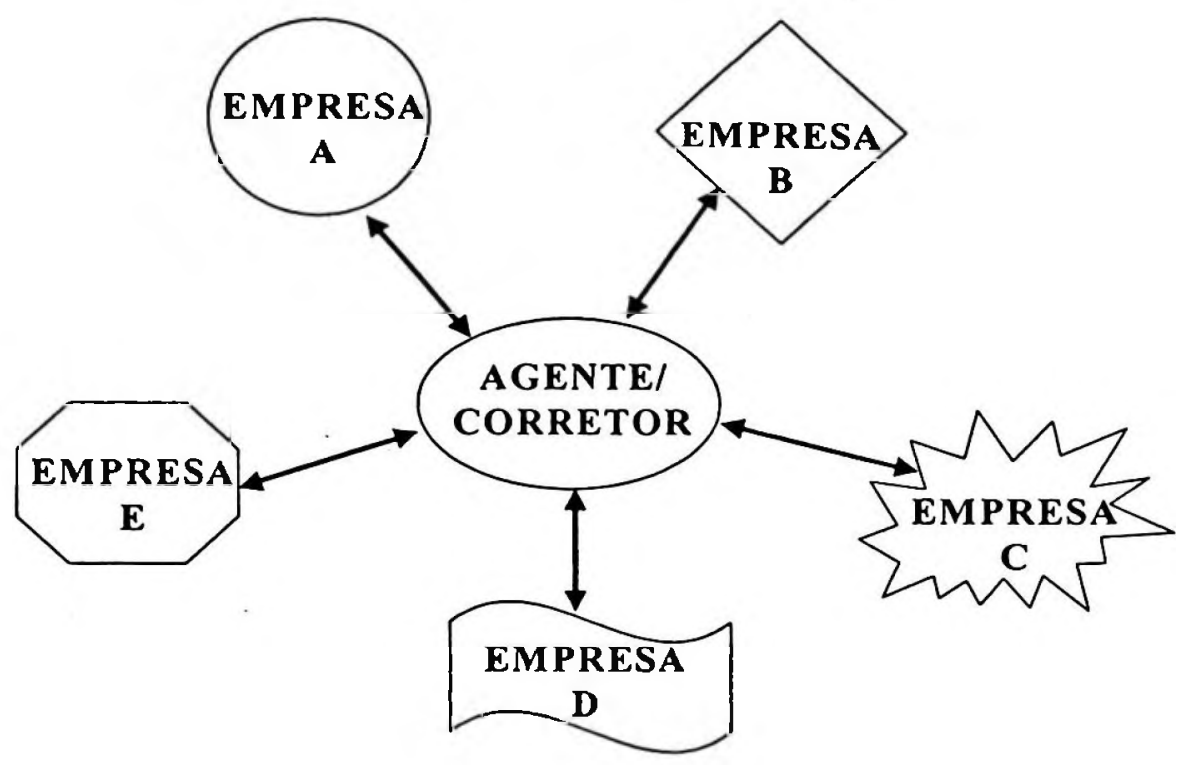

Figura 11: O consultor como agente de conhecimento e tecnologia.

Fonte: SARVARY, M. Knowledge Management and Competition in the consulting Industry. California Management Review, v. 4, n. 2, Winter, 1999.

As grandes empresas de consultoria consideram a gestão do conhecimento uma capacidade essencial para gerar vantagem competitiva. Essas empresas têm aumentado os investimentos em tecnologia da informação, em construção de intranets, banco de dados etc. numa visível mobilização de esforços para construir um sistema de gestão do que pode se considerar a matéria prima dos seus produtos - o conhecimento (DUNFORD, 2000). Essa é uma das principais razões que tornam a gestão do conhecimento uma atividade de suma importância para empresas de consultoria e assessoria. O que se vende, nesses casos, são os conhecimentos e as habilidades que esses profissionais detêm - suas competências para criar soluções e para resolver problemas.

Segundo Davenport; Hansen (1988, apud DUNFORD, 2000), as redes de relacionamento que suportaram o compartilhamento de conhecimento e o engajamento de profissionais da área de consultoria são consideradas insuficientes. Existe o reconhecimento de que grande parte do conhecimento permanece retida na cabeça das pessoas. A menos que haja uma estrutura especialmente voltada para a transferência desse conhecimento para a memória organizacional, ele se vai com as pessoas que deixam a organização (DUNFORD, 2000). 
Projetos de gestão do conhecimento em empresas de serviços baseados em conhecimento têm sido alvos de pesquisa para vários autores. Alguns exemplos serão comentados nesta seção.

Estudo de caso realizado na empresa Ernest \& Young realizado por Chard (1997, apud DUNFORD, 2000) apresenta o sistema de gestão do conhecimento da empresa, que é composto por três centros.

O primeiro é o centro de inovação de negócios (Centre for Business Innovation), cujas atividades são voltadas para a geração de novos conhecimentos.

O segundo é o centro de transformação de negócios (Centre for Business Transformation), onde o conhecimento é transformado em métodos e ferramentas automatizadas.

O terceiro, o centro de conhecimento de negócios (Centre for Business knowledge), que coleta, armazena e sintetiza os conhecimentos gerados interna externamente.

Os três centros operam interconectados e permanecem disponiveis para o acesso dos consultores através da rede de conhecimento da empresa (Knowledge Web). Cada área conta com um grupo de aproximadamente 12 consultores com larga experiência em sua especialidade, para projetar e gerenciar sua base de dados.

Segundo Davenport; De Long, Beer (1998) e Davenport; Pruzak (1998, apud DUNFORD, 2000) a Ernest \& Young investe 6\% de sua receita em sistemas de gestão do conhecimento. A McKinsey destina $10 \%$ de sua receita para essa finalidade. A empresa criou um sistema que conta com:

- uma rede computadorizada para o desenvolvimento de práticas (Practice Development Network). Essa base contém documentos que pretendem representar o conhecimento essencial das áreas de prática;

- um diretório fonte de conhecimento (Knowledge Resource Directory), que traz uma relação de todos os experts da empresa, bem como os títulos dos documentos-chave por área de prática;

- um sistema de informações das práticas da firma (Firm Practice Information System), uma base de dados sobre clientes;

- um centro de pesquisas denominado McKinsey.Global Institute, que estuda os efeitos das mudanças da economia mundial sobre os negócios e 
- uma olimpíada de práticas (Practice Olympics) na qual equipes de várias partes do mundo apresentam idéias novas para o julgamento de um painel de sócios e clientes.

A KPMG Peat Marwick US, conforme relata Dunford (2000), desenvolveu uma rede interna (Knowledge Web - Kweb) como base para as práticas de gestão do conhecimento da empresa, cujo processo envolve seis etapas:

i) aquisição - coleta, sintetização e interpretação de informações provenientes de fontes internas e externas,

ii) indexação - desenvolvimento de esquemas de classificação,

iii) filtragem - separação das informações de acordo com sua importância,

iv) ligação - conexão das informações inter-relacionadas,

v) distribuição das informações e

vi) aplicação.

Foi criado também o centro de compartilhamento de conhecimento (Shared Knowledge Center) responsável pelo desenvolvimento e implementação das políticas e práticas de gestão do conhecimento, alinhadas com as estratégias organizacionais. Esse centro também é responsável pela disseminação da cultura de compartilhamento de conhecimento por toda a organização (ALAVI, 1997 apud DUNFORD, 2000).

No entanto, apesar de todo o esforço, investimentos e tecnologia pouco se pode mensurar em termos de resultados concretos (DUNFORD, 2000). O autor relata que sócios da consultoria Booz, Allen \& Hamilton declararam que, de todos os programas implementados, uma parcela muito pequena apresentou impactos significativos para a empresa no curto prazo. Porém, confessam-se confiantes nos benefícios das iniciativas de gestão do conhecimento e afirmam que no longo prazo as falhas serão cada vez mais raras e os resultados aparecerão.

Para Dunford (2000), há muitas razões para que a construção de um sistema efetivo de gestão do conhecimento se constitua um desafio considerável. Por exemplo, é dificil assegurar que as informações registradas no sistema sejam de alta qualidade.

Há também uma falta de tempo generalizada, os consultores não encontram tempo para registrar seus aprendizados e experiências para alimentar o sistema para que outros 
possam compartilhar. Há ainda um desafio maior que é a criação de uma cultura organizacional que favoreça as práticas de gestão do conhecimento (DUNFORD, 2000).

Na McKinsey, o desenvolvimento de um sistema de compartilhamento do conhecimento exigiu mudanças na estrutura hierárquica interna. Hoje a empresa é referenciada como um modelo de aprendizado conjunto e compartilhamento de conhecimentos. No entanto, por muito tempo perdurou o sentimento de propriedade e a relutância em documentar conceitos, o que restringiu a efetividade da troca de informações, conhecimentos e idéias (DAVENPORT; PRUZAK, 1998 apud DUNFORD, 2000).

Para vencer essa resistência cultural as empresas procuram reconhecer atitudes de compartilhamento e disseminação do conhecimento através de sistemas de remuneração, valorizando-as através dos processos de avaliação de desempenho, introduzindo em suas práticas programas de coaching, mentoring etc.

A Ernest \& Young, por exemplo, introduziu as práticas de gestão do conhecimento na avaliação de performance dos profissionais, com valor proporcional a um quinto em relação aos demais itens avaliados (CHARD, 1997 apud DUNDFOR, 2000).

A Booz, Allen \& Hamilton incluiu em seu sistema de avaliação de performance a contribuição dada aos processos de transferência do conhecimento através do programa de mentoring. Cada consultor deve facilitar e promover o aprendizado e o desenvolvimento dos profissionais menos experientes (DUNFORD, 2000).

Hansen, Nohria; Tiemey (1999) consideram as empresas de consultoria como fontes importantes de estudo. São paradigmas para as empresas que dependem de pessoas, de conhecimentos, de fluxo de informações e idéias.

Os autores destacam dois tipos de estratégias que fundamentam os sistemas de gestão do conhecimento nessas empresas, e que também cabem no contexto de empresas de segmentos diferentes da consultoria: a estratégia da codificação (codification strategy) e estratégia da personalização (personalization strategy)

A estratégia da codificação pressupõe uma ênfase no registro e na reutilização do conhecimento, que os autores denominam abordagem people-to-documents. O conhecimento é extraído da pessoa que o criou e, uma vez independente, é disponibilizado em uma base para ser acessado e reutilizado. Muitas pessoas podem recuperar o conhecimento codificado sem que haja contato algum com a pessoa que o desenvolveu. A utilização do conhecimento 
ocorre em escala e gera economia no tempo de solução de problemas, permitindo redução no custo e conseqüentemente no preço dos serviços. Essa estratégia é mais adequada para empresas que lidam sempre com problemas similares e para um modelo econômico que foca ampla geração de receita.

O foco da estratégia da personalização é o diálogo entre pessoas (abordagem person(o-person). O conhecimento não é codificado. A transferência ocorre por meio de sessões de brain storming e conversas pessoais, reuniões presenciais etc. Os custos envolvidos em viagens para contatos pessoais podem ser reduzidos pela utilização de recursos tecnológicos como a vídeo-conferência, áudio-conferência, contatos telefônicos, chats etc. As empresas que adotam essa estratégia realizam altos investimentos na construção de redes de relacionamentos (networks).

Hansen, Nohria; Tierney (1999) notaram que ao escolher uma das estratégias, as empresas não excluem totalmente a outra, mas sim a exploram como suporte. Por exemplo, empresas que focam a estratégia da personalização utilizam uma base eletrônica, não para registrar e oferecer conhecimento como objeto, mas para registrar informações sobre as pessoas que detêm determinadas expertises, ou experiência em determinada situação. $O$ objetivo é facilitar o contato entre as pessoas para troca de conhecimentos tácitos.

O Quadro 5 reúne as características que diferenciam as duas estratégias.

\begin{tabular}{|l|l|l|}
\hline \multicolumn{1}{|c|}{ CODIFICAÇÃO } & \multicolumn{1}{c|}{ PERSONALIZAÇÃo } \\
\hline $\begin{array}{l}\text { Dispõe de um sistema de } \\
\text { informações de alta qualidade e } \\
\text { confiabilidade para que o } \\
\text { conhecimento codificado possa ser } \\
\text { reutilizado. }\end{array}$ & $\begin{array}{c}\text { ESTRATÉGIA } \\
\text { COMPETITIVA }\end{array}$ & $\begin{array}{l}\text { Oferece soluções criativas com rigor analitico } \\
\text { para problemas estratégicos de alta } \\
\text { complexidade através da promoção da conexão } \\
\text { dos indivíduos que possuem o conhecimento e } \\
\text { as habilidades necessárias. }\end{array}$ \\
\hline $\begin{array}{l}\text { Economia da Reutilização: } \\
\text { Investe uma vez no conhecimento } \\
\text { como um ativo. }\end{array}$ & MODELO \\
$\begin{array}{l}\text { Mantém grandes equipes sob a } \\
\text { coordenação de um sócio. }\end{array}$ & $\begin{array}{l}\text { Economia da Expertise } \\
\text { Foca a geração de altas receitas. }\end{array}$ & $\begin{array}{l}\text { Cobra altos preços por soluções altamente } \\
\text { customizadas para problemas únicos. } \\
\text { Eantém equipes pequenas sob a coordenação } \\
\text { de um sócio. }\end{array}$ \\
\hline
\end{tabular}

Quadro 5: Estratégias de gestão do conhecimento (continua)

Fonte: HANSEN, M. T.; NOHRIA N.; TIERNEY, T. What's your strategy for managing knowledge. Harvard Business Review, Boston, v. 77, n. 2, p. 106-116, Mar./Apr. 1999. 


\begin{tabular}{|c|c|c|}
\hline CODIFICAÇÃO & & PERSONALIZAÇÃO \\
\hline $\begin{array}{l}\text { People - to - Documents } \\
\text { Desenvolve um sistema eletrônico } \\
\text { que codifica, armazena, dissemina e } \\
\text { permite a reutilização do } \\
\text { conhecimento. }\end{array}$ & $\begin{array}{l}\text { ESTRATÉGIA DE } \\
\text { GESTÃO DO } \\
\text { CONHECIMENTO }\end{array}$ & $\begin{array}{l}\text { Person - to - Person } \\
\text { Desenvolve redes de relacionamentos para } \\
\text { conectar as pessoas para que o conhecimento } \\
\text { tácito possa ser compartilhado. }\end{array}$ \\
\hline $\begin{array}{l}\text { Altos investimentos em TI com o } \\
\text { objetivo de conectar as pessoas com } \\
\text { o conhecimento codificado e } \\
\text { reutilizável. }\end{array}$ & $\begin{array}{l}\text { TI } \\
\text { TECNOLOGIA } \\
\text { DA } \\
\text { INFORMAÇÃO }\end{array}$ & $\begin{array}{l}\text { Investimento moderado em } \mathrm{TI} \text {, dando maior } \\
\text { ênfase nas ações que facilitem conversas para } \\
\text { o intercâmbio do conhecimento tácito. }\end{array}$ \\
\hline $\begin{array}{l}\text { - Contrata pessoas recém-formadas, } \\
\text { com perfil adequado à reutilização } \\
\text { de conhecimentos e } \\
\text { implementação de soluções. } \\
\text { - Treina pessoas em grupo. Foca o } \\
\text { aprendizado à distância via } \\
\text { computador. } \\
\text { - Recompensa as pessoas pela } \\
\text { utilização e contribuição com a } \\
\text { base de conhecimentos. }\end{array}$ & $\begin{array}{l}\text { RECURSOS } \\
\text { HUMANOS }\end{array}$ & $\begin{array}{l}\text { - Contrata pessoas pós-graduadas, que } \\
\text { gostam de criar soluções de problemas e } \\
\text { lidam bem com ambigüidades. } \\
\text { - O treinamento é realizado pessoa-a-pessoa } \\
\text { em sistema de mentoring. } \\
\text { - Recompensa as pessoas pelas ações de } \\
\text { compartilhamento de seus conhecimentos. }\end{array}$ \\
\hline
\end{tabular}

Quadro 5: Estratégias de gestão do conhecimento (continuação)

Fonte: HANSEN, M. T.; NOHRIA N.; TIERNEY, T. What's your strategy for managing knowledge. Harvard Business Review, Boston, v. 77, n. 2, p. 106-1 16, Mar./Apr. 1999.

A escolha da melhor estratégia, segundo Hansen, Nohria; Tierney (1999), vai depender da maneira que a empresa cria valor para seus clientes, de como esse valor suporta um modelo econômico e do tipo de pessoas que lidam com esses fatores. Os autores afirmam que uma escolha errada, ou a tentativa de se adotar ambas as estratégias pode significar prejuízos significativos.

Dunford (2000) argumenta que ainda não se apresentaram evidências concretas de que sistemas de gestão do conhecimento são realmente capazes de criar vantagem competitiva. Questiona se uma empresa será capaz de estabelecer vantagem competitiva através de um sistema de gestão do conhecimento, que seja reconhecido pelos potenciais clientes como sinal de serviço superior àqueles oferecidos pelos concorrentes.

A efetiva vantagem proveniente da gestão do conhecimento nas empresas de consultoria depende da limitação de efeitos negativos gerados por outros problemas. Um sistema de gestão do conhecimento de primeira grandeza não será capaz de neutralizar confusões de entendimento sobre os desejos e objetivos dos clientes, processos falhos de 
gerenciamento de clientes, desencontros no direcionamento estratégico da organização, enfim não será capaz de se sobrepor a uma empresa desalinhada e confusa. Um processo para diagnosticar a organização deve preceder a implementação das práticas de gestão do conhecimento (PRINGLE, 1998 apud DUNFORD, 2000).

Criada a vantagem competitiva, a sua sustentabilidade dependerá de dois aspectos: da capacidade da empresa em continuar a entregar serviços percebidos como superiores e da capacidade dos concorrentes em imitar esse serviço.

Com relação à imitação por parte da concorrência, não constitui uma tarefa fácil. As práticas de gestão do conhecimento podem ser transparentes externamente, mas estão entranhadas nas peculiaridades operacionais e permeadas pela cultura organizacional. Sendo assim, os concorrentes podem enxergar, mas não serão capazes de copiar.

Embora a vantagem competitiva não seja o foco deste trabalho, pelo fato de as competências e o conhecimento serem considerados como tal, cabe aqui uma breve abordagem conceitual sobre o tema e suas relações com conhecimento e competências.

\subsection{COMPETÊNCIAS, CONHECIMENTO E VANTAGEM COMPETITIVA}

A questão da vantagem competitiva está intimamente ligada ao conceito de estratégia. Estratégia é um construto tratado pelas teorias de estratégia empresarial, que, segundo Henderson (1998), pode ser definida como o planejamento intencional e deliberado de ações voltadas para o desenvolvimento da vantagem competitiva de uma empresa. É semelhante à definição proposta por Barney (2002, apud VASCONCELOS; BRITO, 2004) de que estratégia é a teoria de como uma empresa pode competir com sucesso, tendo como último objetivo a conquista da vantagem competitiva.

A partir da análise de diversos estudos sobre vantagem competitiva, Vasconcelos; Cyrino (2000) relatam duas correntes de abordagem: a primeira analisa a vantagem competitiva do ponto de vista da sua origem e a segunda separa as abordagens com base em premissas sobre a concorrência (Figura 12). 


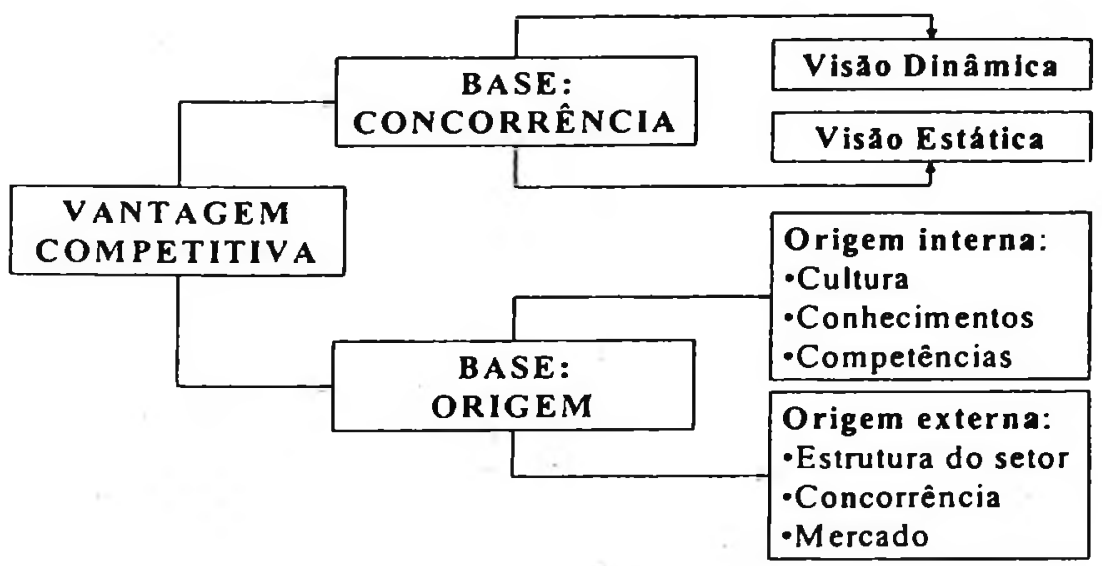

Figura 12: Vantagem Competitiva: correntes de abordagens

Fonte: Autora, com base no estudo de Vasconcelos; Cyrino (2000)

Com base em premissas sobre a concorrência, de um lado há pesquisadores que trazem uma visão estática sobre vantagem competitiva, suportados pela teoria econômica dos mercados perfeitos. De outro lado há os que focam suas características dinâmicas e mutáveis.

Do ponto de vista da sua origem, de um lado se considera a vantagem competitiva um atributo de posicionamento externo à organização, derivado da estrutura da indústria (setor), da dinâmica da concorrência e do mercado. Nessa linha Porter (1998;) afirma que o objetivo estratégico de uma empresa consiste em se colocar na melhor posição dentro do setor em que atua para influenciar as forças concorrentes ao seu favor ou se defender delas. Segundo Porter (1980, apud VASCONCELOS; CYRINO, 2000) a vantagem competitiva é determinada por dois fatores: as condições iniciais e a escolha dos dirigentes.

De outro lado, a vantagem competitiva é vista como uma performance superior decorrente principalmente de características internas da organização e, em um nível secundário, na estrutura do setor em que ela se posiciona.

Essa visão encontra eco na teoria dos recursos, na qual a fonte de vantagem competitiva encontra-se nos recursos internos, desenvolvidos e controlados pela empresa, incluindo não somente os recursos físicos e financeiros, mas também os intangiveis (HALL, 1992, apud VASCONCELOS; CYRINO, 2000).

Segundo Vasconcelos; Brito (2004) não existe ainda uma definição de vantagem competitiva consensualmente aceita pela academia. Registrando-se discussões sobre seus fundamentos lógicos e filosóficos e, até mesmo sobre sua real existência. Com base em 
pesquisa recente envolvendo mais de 2.000 empresas de 16 países, os autores confirmam a existência de vantagem competitiva, seu caráter específico a cada empresa e apresentam uma nova proposta de definição. Os autores definem vantagem competitiva em duas condições: na condição de força componente e na condição de força resultante, em analogia ao campo da fisica.

As vantagens competitivas componentes seriam os fatores isolados associados à empresa de forma única, que exercem influência, positiva ou negativa, sobre seu desempenho. Podem ocorrer fatores que influenciam negativamente piorando desempenho da empresa, que os autores denominam desvantagens competitivas.

A vantagem competitiva resultante é a influência líquida de todos os fatores idiossincráticos da empresa (vantagens competitivas componentes) que afetam seu desempenho.

Quanto à relação entre conhecimento e vantagem competitiva, Von Krogh; Ichijo; Nonaka (2001) distinguem dois tipos de conhecimento organizacional: o conhecimento exclusivo (de domínio da empresa) e o conhecimento público (acessivel para todos). Segundo os autores, o conhecimento exclusivo pode se tornar vantagem competitiva se ele for traduzido em ações de exploração e geração de oportunidades de negócios, ou em ações agregadoras de valor. Se o conhecimento for convertido em ações competentes diferenciadas influenciará positivamente o desempenho da organização em relação à concorrência.

O impacto das competências e do conhecimento organizacional sobre o desempenho das organizações pode ser considerado bastante significativo pois, resgatando as palavras de Drucker $(1994,2001)$, vivemos na sociedade do conhecimento, na qual o conhecimento é o recurso-chave, ficando à frente dos tradicionais recursos capital, terra e trabalho. Quanto às competências, estas se caracterizam como uma das principais fontes de vantagem competitiva para as organizações segundo Prahalad; Hamel (1990).

Para Prahalad; Hamel (1990) as empresas não conseguem mais competir em âmbito global tendo a sua competitividade baseada em custo de produto e qualidade. Esses atributos não se caracterizam mais como fonte de vantagem, são condições mínimas de sobrevivência. No longo prazo a competitividade se fundamenta na capacidade da organização formar competências essenciais com maior rapidez e a custos menores que os da concorrência. A linha de abordagem de Prahalad; Hamel (1990) foca os fatores internos como origem da vantagem competitiva. 
Com seu artigo The core competence of the corporation (A competência essencial da corporação) em 1990, Prahalad; Hamel (1990) chamam a atenção do mundo corporativo para a necessidade de a alta gerência se dedicar ao desenvolvimento de uma arquitetura estratégica com a finalidade de construir e consolidar as competências essenciais da organização. Segundo os autores, as competências essenciais são formadas pelo aprendizado coletivo na organização. Envolve a coordenação de diversas habilidades de produção e a integração de uma variedade de correntes tecnológicas. Para exemplificar, entre outros casos, os autores citam a Casio, cujas competências essenciais foram formadas em miniaturização, projeto de microprocessadores, ciência de materiais e encapsulamento de precisão ultra-fino e são aplicadas em diferentes produtos finais como as miniaturas de calculadoras de cartões, TVs de bolso e relógios digitais. Como também o caso da Honda, cuja competência diferenciada em motores lhe possibilitou passar da fabricação de motos para automóveis.

Vale destacar um exemplo apontado por Fleury (2002) envolvendo uma empresa brasileira. A Embraer focou a formação de suas competências em desenvolvimento e gestão de projetos. Hoje, essa competência é internacionalmente reconhecida, permitindo que a empresa venda produtos que ainda se encontram no papel, contando com parceiros de risco que incluem as maiores empresas do mundo no setor aeronáutico.

As competências essenciais integram negócios essencialmente diferentes em termos de clientes, canais de distribuição e estratégia de mercado, tornando-os coerentes.

A importância da formação das competências essenciais se verifica não somente na indústria, mas também no setor de serviços. Os autores exemplificam com o caso do Citicorp, que ganhou força à frente da concorrência ao conseguir atuar em mercados mundiais 24 horas por dia. Seus investimentos em tecnologia e a formação de competências em sistemas lhe propiciaram essa vantagem.

Segundo Prahalad; Hamel (1990), as competências essenciais se caracterizam como vantagem competitiva três aspectos: i) por proporcionarem acesso potencial a uma ampla variedade de mercados, sendo a fonte geradora do desenvolvimento de novos negócios, como o caso da Casio, citado anteriormente, ii) por darem significativa contribuição à percepção do cliente sobre os beneficios do produto, como o caso dos motores Honda, e iii) por serem de dificil imitação por parte da concorrência. Enquanto os esforços pela consolidação e domínio da marca são relatados pela imprensa e são do conhecimento do mercado e da concorrência, os esforços na formação das competências essenciais são invisiveis externamente, envolvem a instituição de um espírito compartilhado. 
Por todas essas razões os autores afirmam ser de suma importância para uma organização empreender esforços na identificação e localização das competências essenciais para o seu negócio e no desenvolvimento de uma arquitetura estratégica corporativa que estabeleça objetivos para a formação de competências. Da mesma forma que os dirigentes dedicam atenção ao orçamento e alocações de capital financeiro, devem atentar para a alocação dos conhecimentos e habilidades humanas que materializam as competências organizacionais. "Os representantes da corporação devem realizar um exame do local, do número e da qualidade das pessoas que dão corpo à competência" (PRAHALAD; HAMEL 1990, p. 313).

Uma arquitetura estratégica corporativa envolve alocação de recursos consistente e infra-estrutura administrativa adequada, de forma a criar na organização uma cultura gerencial e espírito de equipe capazes de empreender mudanças, compartilhar recursos e proteger as competências organizacionais. A arquitetura estratégica serve de modelo para embasar as decisões da alta gerência e permite que os gerentes intermediários compreendam a lógica por traz da priorização das alocações. Ela também representa mais um recurso para que a organização se comunique com o ambiente externo, revelando a direção ampla sem revelar os passos envolvidos.

Bamey (1991, apud KANDAMPULLY, 2002; VASCONCELOS; CYRINO, 2002), expande o conceito de recursos da empresa para incluir todos os seus ativos, suas capacidades, seus atributos, informações, processos organizacionais, seus conhecimentos e habilidades etc. Kandampully (2002) argumenta que o valor qualquer um desses recursos depende do conhecimento existente no presente. Um novo conhecimento é capaz de transformar qualquer coisa no mundo em recurso, inclusive seres humanos. Isso significa que um recurso valioso hoje, pode deixar de ser no futuro, se algum novo conhecimento desenvolver um substituto superior.

Concluído o levantamento bibliográfico, o capítulo seguinte traz as fundamentações metodológicas que darão sustentação à fase empírica do presente estudo. 
CAPÍtULO 2

FUNDAMENTAÇÕES METODOLÓGICAS 


\subsection{NATUREZA DA PESQUISA DE CAMPO}

Quanto a sua natureza, as pesquisas podem ser exploratórias, descritivas ou experimentais (SELLTIZ et alii, 1974). Para situações em que se pretende maior familiaridade e compreensão mais profunda de um fenômeno, a pesquisa exploratória é indicada pela autora como a mais adequada.

As pesquisas descritivas, segundo Selltiz et alii (1974), são adequadas para estudos que exijam maior precisão, como aqueles que buscam apresentar características de uma situação, de um grupo ou individuo com exatidão, ou os que mensuram a freqüência com que algo ocorre. As pesquisas experimentais são mais adequadas para verificar hipóteses de relação causal entre variáveis.

Como o presente estudo pretende explorar e compreender o processo de desenvolvimento de competências individuais e organizacionais a partir da aplicação de técnicas de gestão do conhecimento e avaliar os resultados dessa aplicação, a pesquisa exploratória foi considerada a mais adequada.

O presente estudo está dividido em duas fases: uma fase teórica constituída por um levantamento bibliográfico e pela construção de um modelo conceitual de gestão do conhecimento, e uma fase empírica constituída por um estudo de caso, cuja estruturação será detalhada a seguir.

\subsection{ESTRATÉGIA DA PESQUISA DE CAMPO}

$\mathrm{Na}$ fase empírica será desenvolvida uma pesquisa de campo do tipo exploratório, conforme exposto no início deste capítulo. Para sua realização, as estratégias consideradas inicialmente foram a pesquisa-ação e o estudo de caso. A opção recaiu sobre o estudo de casos pelo fato da pesquisa-ação não ser adequada ao contexto estudado.

\subsubsection{Justificativa da escolha do estudo de caso para a pesquisa de campo}

Segundo Thiollent (2004), o método da pesquisa-ação pode ser aplicado em diferentes campos como: educação, comunicação, organização, serviço social, difusão de 
tecnologia rural, militância política ou sindical etc. Trata-se de um método ainda em discussão, sendo objeto de críticas por parte de cientistas sociais e profissionais. Verifica-se também uma tendência em achar que pesquisa-ação é sinônimo de pesquisa participativa. Para Thiollent (2004), trata-se de uma compreensão equivocada.

A pesquisa-ação envolve muito mais que a simples participação. O método supõe uma ação planejada que traz um caráter social, educacional, técnico ou outro que não se enquadre nos parâmetros da pesquisa participante. Para uma pesquisa ser caracterizada como pesquisa-ação, o trabalho deve realmente envolver ações por parte dos pesquisadores do problema em estudo. Deve ser uma ação não trivial, isto é, algo que mereça ser investigado.

Thiollent (1997) apresenta a pesquisa-ação aplicada ao contexto organizacional. Afirma que desde a década de 40 é o método adequado para conhecer e intervir nas organizações. As organizações que podem demandar essa estratégia de pesquisa abrangem as empresas de produção ou serviços, administrações públicas, centros de pesquisa científica e tecnológica, associações profissionais ou sindicatos, outras entidades sem fins lucrativos.

A pesquisa-ação envolve um compromisso participativo e depende de determinadas condições para se viabilizar. Thiollent (1997, p. 23) expõe as seguintes condições que tornam possível e sustentável a utilização desse método:

- a iniciativa da pesquisa parte de uma demanda de pessoas ou grupos que não ocupam posições de poder;

- os objetivos são definidos com autonomia pelos atores e pouca interferência de membros da estrutura formal;

- todos os grupos envolvidos no problema escolhido como assunto da pesquisa são chamados para participar do projeto e de sua execução;

- todos os grupos têm a liberdade de expressão e são mantidos informados no desenrolar da pesquisa;

- as possiveis ações decorrentes da pesquisa são negociadas entre proponentes e os membros da estrutura formal e

- em geral, as equipes internas que promovem a pesquisa são auxiliadas por consultores ou pesquisadores externos.

Tais características, inerentes à pesquisa-ação, não se encaixam no contexto no qual se desenvolve o presente estudo.

A iniciativa deste estudo partiu do pesquisador, que ocupa uma posição que the permitiu atuar com alto grau de autonomia na elaboração do projeto. O modelo de gestão do 
conhecimento para desenvolvimento de competências foi elaborado pelo pesquisador para compor o programa Academia de Desenvolvimento de Competências (ADC), sem a participação dos atores.

O objetivo do projeto ADC é o desenvolvimento de um conjunto de competências definido como prioridade por um comitê, do qual o pesquisador faz parte, que envolve também a presidência da empresa.

O objetivo do programa teve sua fundamentação nos objetivos organizacionais, bem como nas estratégias desenhadas para sua concretização. Os atores não tiveram nenhuma participação nessas atividades.

Os atores gozam de liberdade de expressão. Têm pleno conhecimento da importância do desenvolvimento das competências para viabilizar a implementação das estratégias para 0 alcance dos objetivos organizacionais. Eles sabem qual é o objetivo do programa, porém, não têm consciência de que o programa do qual são atores é objeto de pesquisa.

Embora possa contribuir com a empresa estudada como orientação para direcionamentos de ações, a presente pesquisa tem como principal objetivo estudar o processo de desenvolvimento de competências com a utilização de conceitos e técnicas de gestão do conhecimento.

Não há consultores ou pesquisadores externos participando do programa ou prestando qualquer auxílio no seu desenvolvimento.

Por todas essas razões, a opção recaiu sobre a estratégia de estudo de caso para a realização da pesquisa de campo que integra a fase empírica do presente trabalho.

Há, no entanto, que se pontuar um aspecto convergente do método pesquisa-ação com o contexto estudado. Trata-se da possibilidade da interação do pesquisador com o grupo de atores. Essa condição traz importantes contribuições para o presente trabalho. Por essa razão, a observação participante foi adotada como fonte de coleta de dados ou evidências para o estudo de caso. Detalhes serão abordados mais adiante, no item 2.3.4.

A estratégia do estudo de caso pode ser utilizada em várias situações, dentre as quais estão os estudos organizacionais.

A escolha da estratégia, segundo Yin (2001), depende de três fatores: o tipo de questão da pesquisa, a amplitude do controle do pesquisador sobre os eventos comportamentais reais e o grau de enfoque em acontecimentos históricos ou contemporâneos, conforme exposto no Quadro 6. 


\begin{tabular}{|l|l|c|c|}
\hline \multicolumn{1}{|c|}{ ESTRATÉGIA } & $\begin{array}{c}\text { FORMA DE QUESTÃo } \\
\text { DA PESQUISA }\end{array}$ & $\begin{array}{c}\text { EXIGE CONTROLE } \\
\text { SOBRE EVENTOS } \\
\text { COMPORTA-MENTAIS? }\end{array}$ & $\begin{array}{c}\text { FOCALIZA } \\
\text { ACONTECIMENTOS } \\
\text { CONTEMPORÂNEOS? }\end{array}$ \\
\hline Experimento & Como, porque & sim & Sim \\
\hline Levantamento & $\begin{array}{l}\text { Quem, o que, onde, } \\
\text { quantos, quanto }\end{array}$ & não & Sim \\
\hline $\begin{array}{l}\text { Análise de } \\
\text { arquivos }\end{array}$ & $\begin{array}{l}\text { Quem, o que, onde, } \\
\text { quantos, quanto }\end{array}$ & não & Não \\
\hline Pesquisa histórica & como, porque & não & Sim \\
\hline Estudo de caso & como, porque & não & \\
\hline
\end{tabular}

Quadro 6: Situações relevantes para diferentes estratégias de pesquisa Fonte: YIN, R.K. Estudo de caso - planejamento e métodos. Porto Alegre: Bookman, 2001.

Yin (2001: p. 32), descreve o estudo de caso como uma investigação que estuda um fenômeno contemporâneo dentro do seu contexto real, especialmente quando os limites entre o fenômeno e seu contexto não estão claramente definidos.

No caso deste estudo, o fenômeno é a aplicação de conceitos e técnicas de gestão do conhecimento para o desenvolvimento de competências e a efetividade dessa aplicação. Yin (2001) coloca ainda que um estudo de caso pode focar tanto um caso único quanto casos múltiplos. Neste trabalho será realizado o estudo de caso único em empresa do setor de serviços, atuante no segmento de consultoria e assessoria juridica.

Segundo Yin (2001), o estudo de caso único é apropriado para situações que envolvam: i) casos raros ou extremos, ii) caso revelador em que o pesquisador observa a ocorrência de um fenômeno previamente inacessivel à investigação científica, ou iii) quando a unidade de análise representa um caso decisivo para confirmar, contestar ou entender uma teoria, que é a situação na qual se desenvolve o presente estudo.

Há ainda uma distinção entre estudos de caso holísticos (os que analisam a natureza global de apenas uma unidade de análise) e estudo de casos incorporados (aqueles que envolvem sub-unidades de análise incorporadas). O caso objeto do presente estudo se caracteriza como estudo de caso único do tipo holístico, pois envolve uma única unidade de análise. 
O estudo de caso é caracterizado por grande flexibilidade, o que torna muito dificil estabelecer um roteiro rigido e preciso para o desenvolvimento da pesquisa. Porém, é possível verificar quatro fases comuns à maioria dos estudos de casos como: a) delimitação da unidade-caso, b) coleta de dados, c) análise e interpretação dos dados e redação do relatório (GIL, 1994).

Para a realização do presente trabalho, foram considerados cinco componentes, bem como passos elementares para projetos de pesquisa do tipo estudo de caso, sugeridos por Yin (2001), os quais serão abordados a seguir.

\subsection{PROJETO DA PESQUISA DE CAMPO}

Segundo Yin (2001), há cinco componentes importantes que um projeto de estudo de casos deve apresentar: uma questão para estudo; suas proposições (se houver); uma unidade de análise; a lógica que une as informações às proposições; o critério para interpretar os resultados. Estes dois últimos componentes fazem parte da fase de análise dos dados coletados, mas, segundo o autor, foram pouco desenvolvidos nos estudos de casos.

Adicionalmente, Yin (2001) sugere que o projeto contemple os seguintes passos: a delimitação da unidade de análise, a definição das fontes de dados ou evidências, a elaboração do protocolo para o estudo de caso, a coleta, organização e análise dos dados, interpretações e conclusões e, por fim, a redação do relatório. As recomendações do autor são observadas pelo presente trabalho, conforme exposto a seguir.

\subsubsection{Questão para estudo}

A questão que deu origem a este estudo de caso é "como desenvolver competências organizacionais e individuais a partir da utilização de conceitos e técnicas de gestão do conhecimento?", enquadrando-se na premissa de que estudo de casos é estratégia mais indicada para investigar questões do tipo "como" e "porque" (YIN, 2001). 


\subsubsection{Proposições de estudo}

Segundo Yin (2001), a proposição em um estudo de caso é um recurso que dá direção ao que deve ser investigado. Como o presente trabalho é de caráter exploratório, não se verificaram proposições. A pesquisa será direcionada pelos objetivos geral e especificos expostos na introdução do trabalho.

\subsubsection{Unidade de análise}

Segundo Yin (2001), a unidade de análise pode ser um indivíduo, um evento, uma entidade, um programa ou processo organizacional, um processo de tomada de decisão etc. A unidade de análise está dentro de um contexto, sendo importante distinguir as pessoas que compõem a unidade de análise, das pessoas que fazem parte do seu contexto. (YMN, 2001).

Neste estudo a unidade de análise é o grupo de pessoas selecionadas pela empresa pesquisada para integrar a Academia de Desenvolvimento de Competências (ADC) em uma de suas unidades de negócio. Essa unidade específica foi escolhida por estar em fase mais adiantada, em virtude de ter sido a primeira a ter o programa implementado, o que permite uma análise mais ampla em termos de resultados.

A empresa, o setor em que atua (contexto externo), seu contexto interno e os profissionais envolvidos no programa e a alta direção patrocinadora do programa são agentes interferentes que fazem parte do contexto onde o caso se insere. Informações sobre esses aspectos são detalhadas na apresentação dos dados coletados (item 4.1.).

\subsubsection{Fontes de dados ou evidências}

Yin (2001) destaca seis fontes de evidências em um estudo de caso: i) a documentação, ii) os registros em arquivo, iii) as entrevistas, iv) a observação direta, v) a observação participante e vi) os artefatos físicos. O autor esclarece que nenhuma apresenta vantagens indiscutiveis em relação às outras, verificando entre elas uma relação de 
complementaridade. $\mathrm{Na}$ sequiência serão caracterizadas as fontes a serem investigadas na presente pesquisa.

\section{- Análise de documentos e registros em arquivo}

Gil (2002) coloca a análise de registros em arquivo como parte da pesquisa documental. Yin (2001) diferencia as técnicas de análise de documentos da técnica de análise de registros em arquivo. Considera ambas as técnicas muito relevantes para a coleta de dados em qualquer estudo de caso. Para este estudo, será considerada a abordagem de Yin (2001) que considera separadamente as duas técnicas.

Dentro da categoria documentos o autor inclui:

o cartas, memorandos e outros tipos de correspondência;

○ agendas, avisos, minutas de reuniões e relatórios escritos sobre eventos em geral;

o documentos administrativos (propostas, relatórios de aperfeiçoamentos e outros documentos internos);

o estudos ou avaliações formais do mesmo local sob estudo e

o recortes de jornal e outros artigos publicados na mídia.

$\mathrm{Na}$ categoria de registros em arquivo figuram:

o registros de serviços com informações sobre o número de atendimentos em um determinado periodo;

o registros organizacionais como tabelas e orçamentos;

- mapas e tabelas de características geográficas;

o relação de nomes e outros itens relevantes;

o dados provenientes de levantamentos e

o registros pessoais (agendas, diários etc.). 


\section{- Entrevistas}

As entrevistas são comumente definidas como uma conversa com a finalidade de reunir informações. Trata-se de uma definição padrão que tem sido muito discutida por vários autores, porém sem nenhum consenso sobre como uma entrevista deve ser conduzida (BERG, 1998). Destacam-se pelo menos três principais categorias de entrevistas (SELLTIZ, 1974; BERG, 1998; YIN, 2001) comentadas a seguir.

Entrevista padronizada (formal ou estruturada) - utiliza um roteiro formal e estruturado de questões, de maneira a oferecer a todos os respondentes os mesmos estímulos para cada assunto tratado nas questões.

Entrevista não-padronizada (assistemática, informal ou não diretiva) - contrasta com a rigidez da entrevista padronizada, no sentido de não utilizar nenhum roteiro de questões. Esse tipo de entrevista encaixa-se em situações em que o entrevistador não pode saber com antecedência quais seriam as questões necessárias para explorar um determinado assunto.

Entrevista semi-padronizada (parcialmente assistemática, semi-estruturada ou focalizada) - posicionada entre a entrevista padronizada e a não padronizada, essa forma de entrevista pressupõe uma certa quantidade de questões pré-determinadas ou tópicos especiais. Tais questões são normalmente colocadas em uma ordem sistemática e consistente, porém o entrevistador pode e em certas situações é até esperado que ele explore mais do que as respostas às questões pré-determinadas.

Para coleta de dados da presente pesquisa, será utilizada esta terceira categoria de entrevista. Segundo Selltiz (1974), a entrevista focalizada mostra-se eficiente quando se busca explorar os aspectos de uma situação especifica que provocam mudanças na atitude dos que passaram pela experiência de vivenciá-la. No caso do presente trabalho, a situação vivenciada é o programa de desenvolvimento de competências, unidade de análise do estudo ora desenvolvido. Na entrevista focalizada, o entrevistador pode distinguir entre fatos objetivos e definições subjetivas da situação, pois tem conhecimento antecipado sobre o conteúdo da experiência. Neste trabalho, a entrevista focalizada tem como objetivo levantar a percepção dos participantes do programa quanto à contribuição do programa para o desenvolvimento das competências dos profissionais en desenvolvimento. 


\section{- Observação direta e observação participante}

A observação, tão comumente utilizada no cotidiano das pessoas, pode também ser utilizada como um instrumento de coleta de informações em uma pesquisa científica desde que 4 premissas sejam observadas: i) que sirva a um objetivo formulado de pesquisa, ii) que seja planejada de maneira sistêmica, iii) que seja sistematicamente registrada e ligada a proposições mais gerais e iv) que seja submetida à verificação e controles de validade e precisão (SELLTIZ, 1974, p. 225).

Gil (2002) coloca o método da observação em lugar de destaque na literatura sobre metodologia de pesquisa, classificando-o como a maneira mais apropriada para se conhecer uma situação tal como é na realidade, principalmente no campo das ciências sociais e da psicologia.

A observação participante é um tipo específico de observação. Difere da observação direta pelo fato de o pesquisador participar do grupo ou da situação investigada, podendo inclusive interagir com os participantes (GIL, 2002; YIN, 2001).

A observação direta e a participante também serão adotadas como fonte de evidências no presente estudo de caso.

Para Yin (2001), a observação participante propicia oportunidades raras, como a possibilidade de participar de eventos ou de grupos que, de outra forma, a investigação cientifica não teria acesso, ou a possibilidade de observar a realidade como parte do caso estudado, não somente de um ponto de vista externo. O autor ressalta a possibilidade de manipulação de eventos no método da observação participante. Reconhece que essa manipulação não é tão precisa como em um experimento, mas pode trazer contribuições significativas aos objetivos da coleta de dados. É esta fase da coleta de dados que converge com aspectos da pesquisa-ação, conforme exposto no início desta seção. $O$ pesquisador, como integrante da empresa estudada e idealizador do modelo aplicado no programa ADC, tem a possibilidade de interagir diretamente com os atores da pesquisa.

Como desvantagem, destaca-se a possibilidade de ocorrer pontos de vistas tendenciosos e o fato de o observador participante não dispor de tempo suficiente para fazer anotações e questionar eventos e situações sob perspectivas diferentes (YIN, 2001). Porém, como mencionado anteriormente, o entrevistador pode ter controle sobre visões subjetivas da situação, por ter conhecimento prévio sobre o conteúdo e o objetivo da experiência. Os 
indicadores de eficácia selecionados para avaliar os resultados do programa, minimizarão substancialmente a incidência de visões subjetivas.

\section{- Artefatos físicos}

Os artefatos físicos envolvem todo tipo de evidências fisicas como aparelhos tecnológicos, ferramentas e instrumentos, obras de arte etc. muito utilizados em pesquisas antropológicas, mas que, segundo Yin (2001), têm menor importância na maioria dos estudos de casos. Esta fonte de evidência não se mostrou relevante para os objetivos do presente estudo.

Yin (2001) estabelece três princípios a serem seguidos na fase de coleta de dados, que auxiliam o pesquisador a realizar um estudo de maior validade e confiabilidade: i) a utilização de várias fontes de evidências - triangulação, ii) a criação de um banco de dados e iii) manutenção do encadeamento das evidências.

A utilização de várias fontes de evidências, denominada triangulação, é recomendada para que o resultado do estudo seja mais convincente e acurado, trazendo uma fotografia melhor e mais substancial da realidade (YIN, 2001; BERG, 1998).

Atendendo ao primeiro princípio, foram selecionadas para esta pesquisa, as seguintes fontes de evidências: entrevistas focalizadas envolvendo os participantes do programa, a análise de documentos relacionados ao fato estudado (estruturação do programa, memorandos e relatórios), os registros em arquivo (indicadores quantitativos de desempenho e outros que se fizerem necessários, se autorizados), a observação direta e participante.

Em relação à necessidade de organização dos dados coletados, Berg (1998) argumenta que existem muitos cursos e livros que trazem descrições detalhadas sobre estruturas de pesquisa. Muito poucos, porém, trazem orientações sobre a organização e análise de dados. Acrescenta que muitos pesquisadores com excelentes idéias, projetos adequadamente estruturados e teoricamente bem fundamentados, se perdem nesse ponto sem saber o que fazer diante da montanha de dados coletados. A solução desse problema é foco do segundo principio proposto por Yin (2001) para uma boa coleta de dados: a criação de um banco para a organização dos dados coletados. Embora o autor proponha a distinção entre um banco de dados separado e o relatório, reconhece que essa prática não se tomou institucionalizada. Muito freqüentemente, os dados de um estudo de caso se confundem com 
as evidências apresentadas no respectivo relatório. No entanto, a falta desse cuidado pode se caracterizar a principal defíciência do estudo de casos como estratégia de pesquisa.

Em atendimento a esse princípio, neste trabalho o banco de dados será alimentado pelas anotações resultantes da análise documental e de registros em arquivo, pelos relatos das entrevistas, pelas anotações resultantes da observação participante, bem como pela transcrição das entrevistas realizadas. Os dados coletados serão classificados e organizados em pastas abertas para cada um dos objetivos da pesquisa.

Para atender ao terceiro princípio, a manutenção do encadeamento das evidências será suportada pelo protocolo de estudo de caso, pela lógica estabelecida entre os dados e os objetivos do estudo e pela própria estruturação do projeto da pesquisa de campo.

\subsubsection{Lógica que une as informações às proposições}

Segundo Yin (2001), esta é uma etapa que não foi bem definida para estudos de casos, porém, trata-se de um componente importante. A relação lógica entre as proposições e os dados coletados para sua comprovação é um elemento imprescindível para dar consistência à pesquisa. Por se tratar de um estudo de caráter exploratório, não se verificando proposições, a ligação lógica será estabelecida entre os dados coletados e os objetivos do trabalho, conforme demonstrado no Apêndice 1 (p. 168).

\subsubsection{Critérios de interpretação dos resultados}

Embora não exista uma forma precisa de estabelecer tais critérios, a interpretação se fundamentará na comparação entre a realidade revelada pelos dados coletados e a literatura abordada na fase teórica do presente estudo, buscando-se os pontos de convergência e/ou divergência, verificados entre as práticas organizacionais e a teoria correspondente. 


\subsection{LIMITAÇÕES DA ESTRATÉGIA DE ESTUDO DE CASO}

Existem alguns preconceitos com relação à utilização do estudo de casos como estratégia de pesquisa.

Um dos preconceitos refere-se à falta de base suficiente para se realizar uma generalização científica. Yin (2001, p.29) argumenta que os estudos de caso, como os experimentos, são generalizáveis a proposições teóricas, e não a populações ou universos". Acrescenta que "o objetivo do pesquisador é expandir e generalizar leorias (generalização analitica) e não enumerar freqüências (generalização estatística).

Outro preconceito diz respeito ao tempo demorado para se concluir um estudo de caso. O autor afirma que os estudos de caso não precisam demorar muito para serem consistentes. Atribui essa visão à forma como os estudos de casos eram realizados no passado. Havia uma confusão com um determinado método de coleta de dados demorada, como a etnografia que demanda longos periodos de observação em campo para sua realização.

O terceiro refere-se à deficiência de rigor metodológico. Yin (2001) atribui essa visão equivocada a utilizações negligentes dessa estratégia de pesquisa por usuários despreparados, que podem ter se utilizado de evidências equivocadas ou da influência de visões tendenciosas em suas descobertas. Verifica-se também uma confusão entre o estudo de caso como método de pesquisa do estudo de caso como recurso didático. Como recurso didático, o estudo de caso pode ser manipulado para melhor ilustrar uma questão estudada.

O protocolo proposto pelo autor para um estudo de caso, que será adotado nesta pesquisa e apresentado na seqüência, consolida a sua validade e confiabilidade como estratégia de pesquisa.

\subsection{PROTOCOLO PARA O ESTUDO DE CASO}

O protocolo é um instrumento que engloba as regras e os procedimentos a serem seguidos em um estudo de caso. Yin (2001) afirma que o protocolo é essencial em estudos de casos múltiplos, mas recomenda sua elaboração em qualquer circunstância, por ser uma tática importante para aumentar a confiabilidade da pesquisa, bem como para orientar o pesquisador na condução do trabalho. 
O protocolo recomendado por Yin (2001) é composto por quatro seções: visão geral do estudo de caso, procedimentos de campo, questões do estudo de caso e guia para o relatório do estudo de caso - detalhadas a seguir.

\subsubsection{Visão geral do projeto - informações prévias, contexto e perspectivas}

O projeto envolve um estudo de caso sobre a utilização de conceitos e técnicas de gestão do conhecimento, aplicados a um programa especialmente elaborado para 0 desenvolvimento de determinadas competências individuais e organizacionais. O programa, denominado Academia de Desenvolvimento de Competências (ADC), constitui a unidade de análise da presente pesquisa. Sua delimitação é o grupo pertencente a uma das unidades de negócios da empresa estudada. A escolha se justifica pelo fato dessa unidade ter o programa implementado há mais tempo que as demais unidades de negócios, oferecendo oportunidades de análise mais ampla em termos de resultados em um período de tempo maior. O periodo analisado nesta pesquisa vai de outubro de 2003 a outubro/2004.

O programa inova por envolver um sistema de gestão do conhecimento para o desenvolvimento das competências de seus profissionais. Este estudo pretende investigar como essas técnicas estão sendo aplicadas e quais resultados estão sendo colhidos. Para tanto serão objetos de investigação:

- o contexto em que se insere a unidade de análise;

- o modelo de competências da empresa (plano ideal) e as competências deficientes (plano real), cujo desenvolvimento é foco do programa ADC;

- o programa ADC;

- os participantes (diretos e indiretos) do programa ADC e

- indicadores que permitam avaliar o desempenho do programa.

\subsubsection{Procedimentos de Campo}

Segundo Yin (2001), os tópicos que compõem os procedimentos de campo podem variar dependendo do tipo de estudo realizado, mas destaca cinco tarefas, descritas a seguir, as quais considera principais focos de atenção do pesquisador. 
- Obter acesso à organização e aos entrevistados.

Para este trabalho, o acesso à empresa em estudo, bem como aos entrevistados está garantido, uma vez que o pesquisador faz parte do quadro de colaboradores da empresa estudada.

- Possuir materiais e recursos suficientes quando estiver em campo.

Pelo fato de o pesquisador fazer parte do quadro de colaboradores da empresa estudada, é fácil o acesso a recursos como computador, impressora, papel, telefone, internet, local isolado para tomar notas etc.

- Desenvolver um procedimento para pedir ajuda e orientação, se necessário, de pesquisadores e colegas de outros estudos de caso.

Como se trata de uma dissertação de mestrado, o pesquisador conta com o suporte de uma orientação formal, bem como acesso a outros pesquisadores integrantes do curso de mestrado, que poderão prestar auxílio em caso de necessidade.

- Estabelecer agenda das atividades de coleta de dados (Apêndice 3, p. 170).

- Preparar-se para acontecimentos inesperados como mudanças de agenda, alteração de humor e motivação dos pesquisadores.

A atividade de pesquisa foca um caso único e será realizada por um pesquisador apenas. $O$ grande interesse do pesquisador em concluir o trabalho traz o risco de desmotivação a níveis mínimos. Quanto à disponibilidade dos entrevistados, existe a flexibilidade de contato e adequações de agenda pelo fato de o pesquisador integrar o quadro de colaboradores da empresa estudada.

\subsubsection{Questões do estudo de caso}

As questões do estudo de caso constituem o ponto central do protocolo e apresentam duas características distintivas: 
i) devem ser feitas ao pesquisador, não aos respondentes, pois funcionam como lembretes sobre quais informações coletar e os motivos pelos quais devem ser coletadas e

ii) para cada questão deve haver uma relação de fontes que poderão fornecer as evidências procuradas.

As questões elaboradas para o presente estudo de caso são apresentadas no Quadro 7. São questões intrinsecamente relacionadas aos objetivos do trabalho que as fundamentaram.

\begin{tabular}{|c|c|}
\hline QUESTÕES DO ESTUDO DE CASO & FONTES PROVÁVEIS DE DADOS/EVIDÊNCIAS \\
\hline $\begin{array}{l}\text { Qual o contexto em que a pesquisa se } \\
\text { desenvolve? }\end{array}$ & $\begin{array}{l}\text { Análise setorial publicada pela Gazeta Mercantil em } 2002 \\
\text { (a mais recente). } \\
\text { Arquivo e matérias publicadas em jornais e revistas sobre } \\
\text { o setor juridico. } \\
\text { Documentos e registros em arquivo. } \\
\text { Código de Ética da OAB. }\end{array}$ \\
\hline $\begin{array}{l}\text { Como a empresa elegeu as competências } \\
\text { organizacionais? } \\
\text { Como foram identificadas as deficiências a serem } \\
\text { tratadas pelo programa ADC? }\end{array}$ & $\begin{array}{l}\text { Slides de apresentação do modelo de gestão por } \\
\text { competências quando da sua concepção. } \\
\text { Materiais produzidos no workshop de apresentação e } \\
\text { consolidação do modelo de gestão por competências. } \\
\text { Projeto do sistema de gestão por competências. } \\
\text { Documentos de divulgação da missão, visão de futuro e } \\
\text { objetivos organizacionais. } \\
\text { Resultados do processo de mapeamento. } \\
\text { Relatórios e memorandos sobre o assunto }\end{array}$ \\
\hline $\begin{array}{l}\text { Como foi projetado o programa ADC? } \\
\text { Quais os objetivos do programa? } \\
\text { Como está composto o grupo integrante do } \\
\text { programa? } \\
\text { Como o programa funciona na prática? }\end{array}$ & $\begin{array}{l}\text { Projeto do programa ADC. } \\
\text { Relatórios das reuniões de compartilhamento. } \\
\text { Memorandos e correspondências internas e } \\
\text { Observação direta e participante dos eventos que } \\
\text { integram o programa. }\end{array}$ \\
\hline $\begin{array}{l}\text { Quais os indicadores de desempenho do } \\
\text { programa nos momentos T0 e T1? } \\
\text { Que resultados esses indicadores apresentam? }\end{array}$ & $\begin{array}{l}\text { Documentos e registros em arquivo como: relatórios de } \\
\text { avaliação de desempenho, relatórios comerciais e } \\
\text { financeiros, resultados da pesquisa de satisfação de } \\
\text { clientes e registros de comunicação institucional. }\end{array}$ \\
\hline $\begin{array}{l}\text { Como se configura o modelo de GC aplicado no } \\
\text { programa ADC? }\end{array}$ & Dados coletados sobre o programa. \\
\hline
\end{tabular}

Quadro 7: Questões do estudo de caso

Fonte: Autora 


\subsubsection{Guia para o relatório do estudo de caso}

Normalmente esse item não é observado na maioria dos projetos de estudos de casos. Yin (2001) reconhece que o planejamento do relatório final não é um problema fácil de se lidar, pois não há esquemas uniformes. No entanto, defende a idéia de que algum planejamento é necessário nesse estágio.

Primeiro deve haver uma preocupação com o público para o qual o relatório é dirigido (YIN, 2001; GIL, 1989). No caso do presente trabalho o público destinatário são os integrantes de uma banca de mestrado. Para esse tipo de público, Yin (2001: p.162) coloca que é importante atentar para as indicações dos cuidados que estão sendo tomados durante a pesquisa e as evidências que o estudante obteve com sucesso em todas as fases do projeto de pesquisa. Yin (2001) discute seis alternativas para estruturar um relatório de pesquisa: estruturas analíticas lineares, estruturas comparativas, estruturas cronológicas, estruturas de construção da teoria, estruturas de incerteza e estruturas não seqüenciais. Entre as seis, o autor destaca a estrutura analítica linear como a alternativa mais adequada e mais utilizada em artigos e publicações especializadas em ciência experimental e em estudos de casos.

Para o presente estudo optou-se pela estrutura analítica linear para a elaboração do relatório, cujos tópicos obedecem a seguinte seqüência:

- tema e problema estudados (introdução),

- fundamentações teóricas - revisão da literatura relevante sobre o tema estudado;

- fundamentação metodológica;

- apresentação dos dados coletados e análise das descobertas e

- conclusões e implicações feitas a partir das descobertas.

Esses tópicos estão organizados segundo a estrutura apresentada na página xiv.

Definido o método e a seqüência de ações necessárias para a realização da pesquisa, o passo seguinte foi a implementação dessas ações pelo pesquisador, sob a supervisão de sua orientadora. Os capítulos seguintes apresentam a segunda parte do estudo, os resultados, iniciando pela elaboração do modelo conceitual de GC resultante da pesquisa literária. $O$ Apêndice 2 (p. 169) traz o plano de trabalho e o cronograma de execução do presente estudo. 
PARTE 2

RESULTADOS 
CAPÍTULO 3

RESULTADOS DA FASE TEÓRICA 


\subsection{ELABORAÇÃO DO MODELO CONCEITUAL DE SISTEMA DE GC}

Satisfazendo o primeiro objetivo específico descrito na introdução do trabalho (p. 4), este capítulo trata da elaboração do modelo conceitual de sistema de gestão do conhecimento, resultante da convergência das contribuições dos vários autores abordadas neste trabalho.

A utilização de técnicas de gestão do conhecimento para o desenvolvimento de competências encontra sustentação teórica nas relações entre os elementos que compõem as competências e as características atribuidas ao conhecimento encontradas na literatura.

Pelas definições de competências dos diversos autores abordados, a competência pode ser considerada um conjunto de saberes, conforme demonstra a sintese apresentada no Quadro 8.

\begin{tabular}{|c|c|c|}
\hline AUTORES & COMPETÊNCIAS = MOBILIZAÇĀO DE SABERES & SABERES \\
\hline $\begin{array}{l}\text { McClelland } \\
\text { (1973) }\end{array}$ & $\begin{array}{l}\text { - Conhecimento (o saber necessário para realizar algo) } \\
\text { - Aptidões (talento natural, passível de aprimoramento), } \\
\text { - Habilidades (aplicação prática de um talento) e }\end{array}$ & $\begin{array}{l}\text { Saber } \\
\text { Saber fazer } \\
\text { Saber fazer }\end{array}$ \\
\hline $\begin{array}{l}\text { Medef } \\
(1998)\end{array}$ & $\begin{array}{ll}\text { - } & \text { Conhecimentos, } \\
\text { - } & \text { Saber fazer, } \\
\text { - } & \text { Experiências e } \\
\text { - } & \text { Comportamentos }\end{array}$ & \begin{tabular}{|l} 
Saber \\
Saber fazer \\
Saber empírico \\
Saber ser
\end{tabular} \\
\hline $\begin{array}{l}\text { Zarifian } \\
(2001)\end{array}$ & $\begin{array}{l}\text { Capacidade de tomar iniciativa, de ir além do que está } \\
\text { prescrito, de compreender e dominar novas situações, de } \\
\text { assumir responsabilidade sobre elas. Saber aprender. } \\
\text { Entendimento prático de situações com base em } \\
\text { conhecimentos adquiridos em experiências anteriores, } \\
\text { transformados e ampliados, na medida da diversidade das } \\
\text { situações. Capacidade de mobilizar pessoas e fazer com que } \\
\text { elas compartilhem ações e responsabilidades. }\end{array}$ & $\begin{array}{l}\text { Saber agir responsável } \\
\text { Saber empirico } \\
\text { Saber aprender } \\
\text { Saber mobilizar } \\
\text { recursos }\end{array}$ \\
\hline $\begin{array}{l}\text { Fleury } \\
(2002)\end{array}$ & $\begin{array}{l}\text { Saber agir responsàvel e reconhecido que implica mobilizar, } \\
\text { integrar, transferir conhecimentos, recursos, habilidades, que } \\
\text { agregue valor econômico à organização e valor social ao } \\
\text { individuo. }\end{array}$ & $\begin{array}{l}\text { Saber agir responsável } \\
\text { Saber mobilizar } \\
\text { Saber integrar } \\
\text { Saber transferir } \\
\text { Saber utilizar recursos } \\
\text { Saber fazer }\end{array}$ \\
\hline
\end{tabular}

Quadro 8 - Conjunto de saberes inerentes à competência (continua)

Fonte: Autora, com base nos conceitos de competência dos autores estudados. 


\begin{tabular}{|l|l|l|}
\hline AUTORES & COMPETÊNCIAS = MOBILIZAÇÃO DE SABERES & \multicolumn{1}{|c|}{ SABERES } \\
\hline $\begin{array}{l}\text { Dutra } \\
(2001, \\
2004)\end{array}$ & $\begin{array}{l}\text { Conhecimentos, } \\
\text { Habilidades e } \\
\text { Atitudes }\end{array}$ & $\begin{array}{l}\text { Saber } \\
\text { Saber fazer } \\
\text { Saber ser }\end{array}$ \\
\hline $\begin{array}{l}\text { Le Boterf } \\
(2003)\end{array}$ & $\begin{array}{l}\text { Mobilização dos recursos pessoais (conhecimentos, } \\
\text { habilidades e atitudes) e dos recursos do meio (tecnologia, } \\
\text { livros, redes de relacionamentos etc.). }\end{array}$ & $\begin{array}{l}\text { Saberes teóricos } \\
\text { Saberes do meio } \\
\text { Saberes procedimentais } \\
\text { Saber-fazer formal } \\
\end{array}$ \\
& & $\begin{array}{l}\text { Saber-fazer empírico } \\
\text { Saber-fazer cognitivo } \\
\text { Saber ser } \\
\text { Saber emocional }\end{array}$ \\
\hline
\end{tabular}

Quadro 8 - Conjunto de saberes inerentes à competência (continuação)

Fonte: Autora, com base nos conceitos de competência dos autores estudados.

Pode-se observar que os saberes apresentados por Le Boterf (2003) como componentes da competência abrangem aqueles apresentados pelos outros autores, caracterizando o conjunto mais completo de saberes.

Tais saberes se localizam entre os niveis mais objetivos do individuo, como por exemplo, os saberes teóricos, e os níveis mais subjetivos, como por exemplo, os saberes cognitivos. O dicionário Aurélio (1980, p. 1509) define saber como:

1) ter conhecimento, ciência, informação ou noticia de, conhecimento. 2) Ter conhecimentos técnicos e especiais, relativos a, ou próprios para. ... 4) Ser instruído em; conhecer. 5) Ter meios, capacidade para, conseguir. 6) Ter capacidade, conhecimento para... 8) Poder explicar, compreender... 12) julgar, considerar.... 17) Erudição, sabedoria. 18) Prudência, tino, sensatez, 19) Experiência prática.

Pode-se dizer, então, que os saberes envolvidos no conceito de competência podem ser considerados ora como conhecimento explícito - saberes teóricos, saberes sobre o meio ambiente, saberes procedimentais, saber-fazer formal - ora como conhecimento tácito saberes empíricos (habilidades) saberes cognitivos, saber ser (atitudes e comportamentos) recursos emocionais etc. $\mathrm{O}$ grau de dificuldade da transferência do conhecimento e do aprendizado, portanto, varia de acordo com o nivel de subjetividade ou de objetividade do saber.

O conhecimento, conforme colocam Nonaka; Takeuchi (1997), classifica-se como tácito ou explícito. O conhecimento explícito é expresso em palavras, números, códigos, 
fórmulas, sendo por isso facilmente compartilhado. O conhecimento tácito, por ser de natureza subjetiva e intuitiva, é de difícil formalização e compartilhamento.

Assim sendo, os saberes que caracterizam as competências podem ser considerados diferentes tipos de conhecimentos, classificados nos níveis tácito ou explícito (Figura 13). Dessa forma as competências podem ser efetivamente desenvolvidas a partir de técnicas de gestão do conhecimento. Para Eboli (2002), através da gestão do conhecimento é possível construir as competências capazes de proporcionar diferenciação estratégica para a empresa. Fleury (2001), reforça a proposição afirmando que a gestão do conhecimento se relaciona aos processos de aprendizagem, de aquisição, desenvolvimento, disseminação e registro do conhecimento que faz parte de um processo maior de criação coletiva das competências organizacionais.

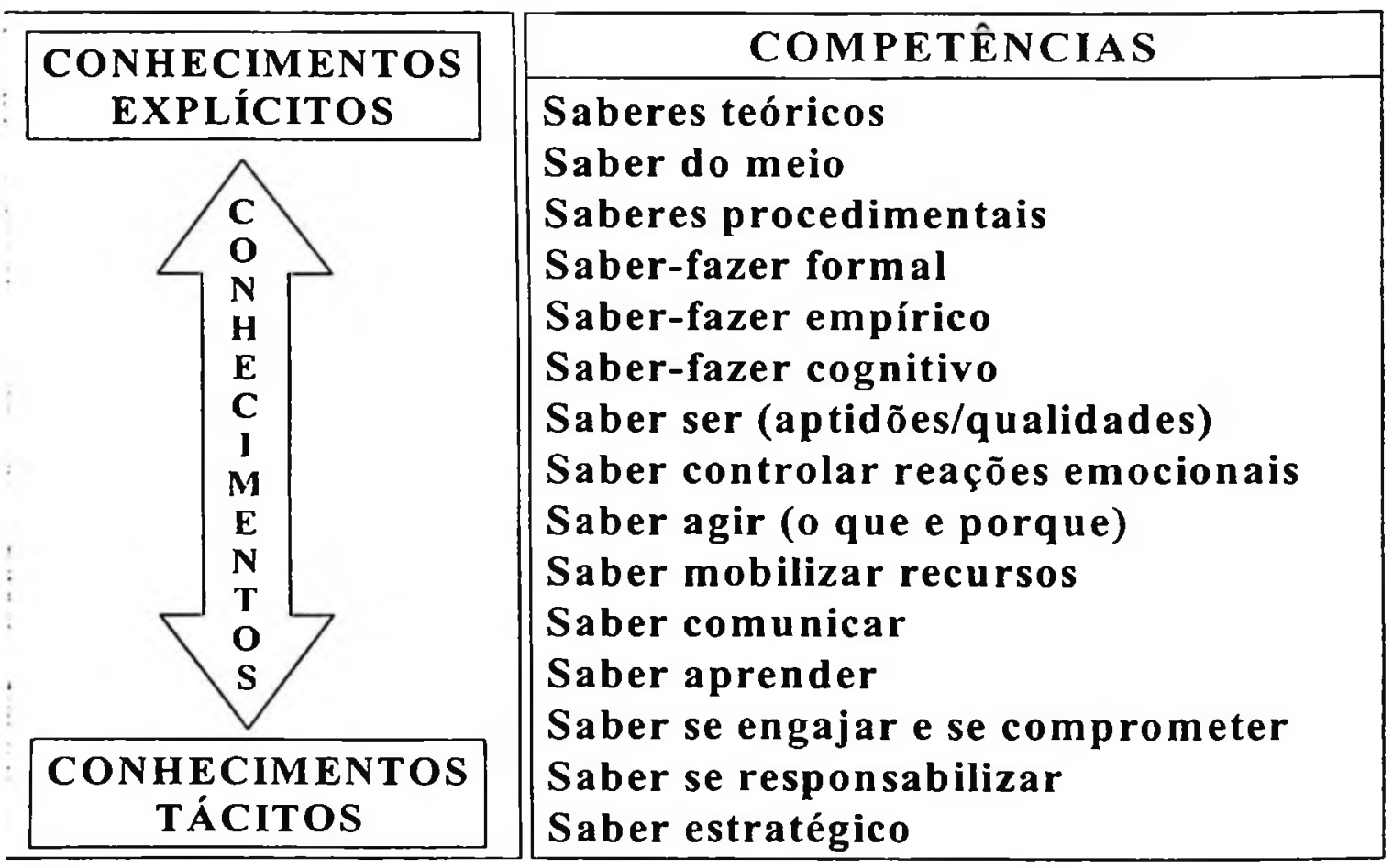

Figura 13: Relações entre competências e conhecimentos

Fonte: Autora, com base nos conhecimentos estudados

Pode-se dizer, então, que competência é um conjunto de conhecimentos que, combinados, resultam em uma ação competente. 


\subsubsection{O caminho do conhecimento individual ao conhecimento organizacional}

Conforme afirmam Nonaka; Takeuchi (1997), a organização não cria conhecimento sozinha. A formação do conhecimento individual é o ponto de partida para a formação do conhecimento organizacional.

A informação é a matéria prima que dá origem ao conhecimento (SARVARY, 1999). Segundo Choo (2003) ela está na base da organização do conhecimento. Davenport; De Long; Beers (1998) complementam argumentando que o conhecimento dos indivíduos deriva de uma combinação entre informação, interpretação, reflexão e experiência dentro de um contexto. Deve-se também considerar o apoio dos conhecimentos anteriores (ZARIFIAN, 2001 ) e a importância da combinação dos saberes (LE BOTERF, 2003).

Em outras palavras, para formar seu conhecimento é necessário que o indivíduo receba informações e que as processe interiormente. O processo interno implica em reflexão, interpretação e conexão das novas informações com os conhecimentos ou os saberes que já possui, para posterior aplicação em suas experiências no contexto em que atua.

Para que os indivíduos se sintam estimulados a realizar esse processo interno de transformação de informações em conhecimento, é necessário que eles encontrem significado para esse aprendizado. Para isso, conforme argumentam Perez-Bustamente (1999) e Von Krogh; Ichijo; Nonaka (2001), as pessoas devem ter uma visão clara do conhecimento a ser desenvolvido para estimular o compromisso com o desenvolvimento desse conhecimento e sua operacionalização. A visão compartilhada do conhecimento a ser desenvolvido funciona como um mapa mental que orienta os individuos em três áreas correlatas: a) do mundo em que vivem, b) do mundo em que devem viver e c) o conhecimento que devem desenvolver para percorrer o caminho entre esses dois mundos. Le Boterf (2003) traz sua contribuição reforçando a necessidade de que cada ato tenha um significado para o profissional. Para isso deve estar inserido em um contexto maior que se estende da micro-ação (apertar um parafuso) à macro-ação (construir um carro).

Para formar o conhecimento organizacional o individuo precisa exteriorizar seu conhecimento, que se forma em duas dimensões - uma tácita e outra explícita. A formação do conhecimento organizacional ocorre pela conversão combinada dessas duas dimensões, realizada pelos indivíduos. 
Resgatando os conceitos do modelo de conversão do conhecimento de Nonaka; Takeuchi (1997), o conhecimento individual pode ser transferido a outros de quatro maneiras: pela externalização (o conhecimento tácito é convertido em explícito para ser transferido a outro indivíduo), pela internalização (o conhecimento explicito é interiorizado e incorporado na dimensão tácita do indivíduo), pela socialização (o conhecimento na dimensão tácita de um individuo é transferido diretamente para a dimensão tácita do outro indivíduo) e pela combinação (o conhecimento codificado, na dimensão explícita, é transferido para a dimensão explicita de outro indivíduo). Pelos modos de conversão, o conhecimento individual pode ser transferido e disseminado para todos os niveis organizacionais. $\mathrm{O}$ caminho do conhecimento individual ao conhecimento organizacional está representado na Figura 14.

Himisintes Relaciones

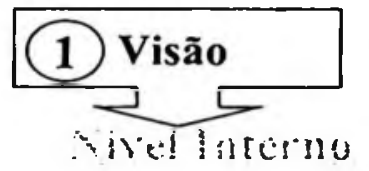

Estruturas e Infra-estruturas

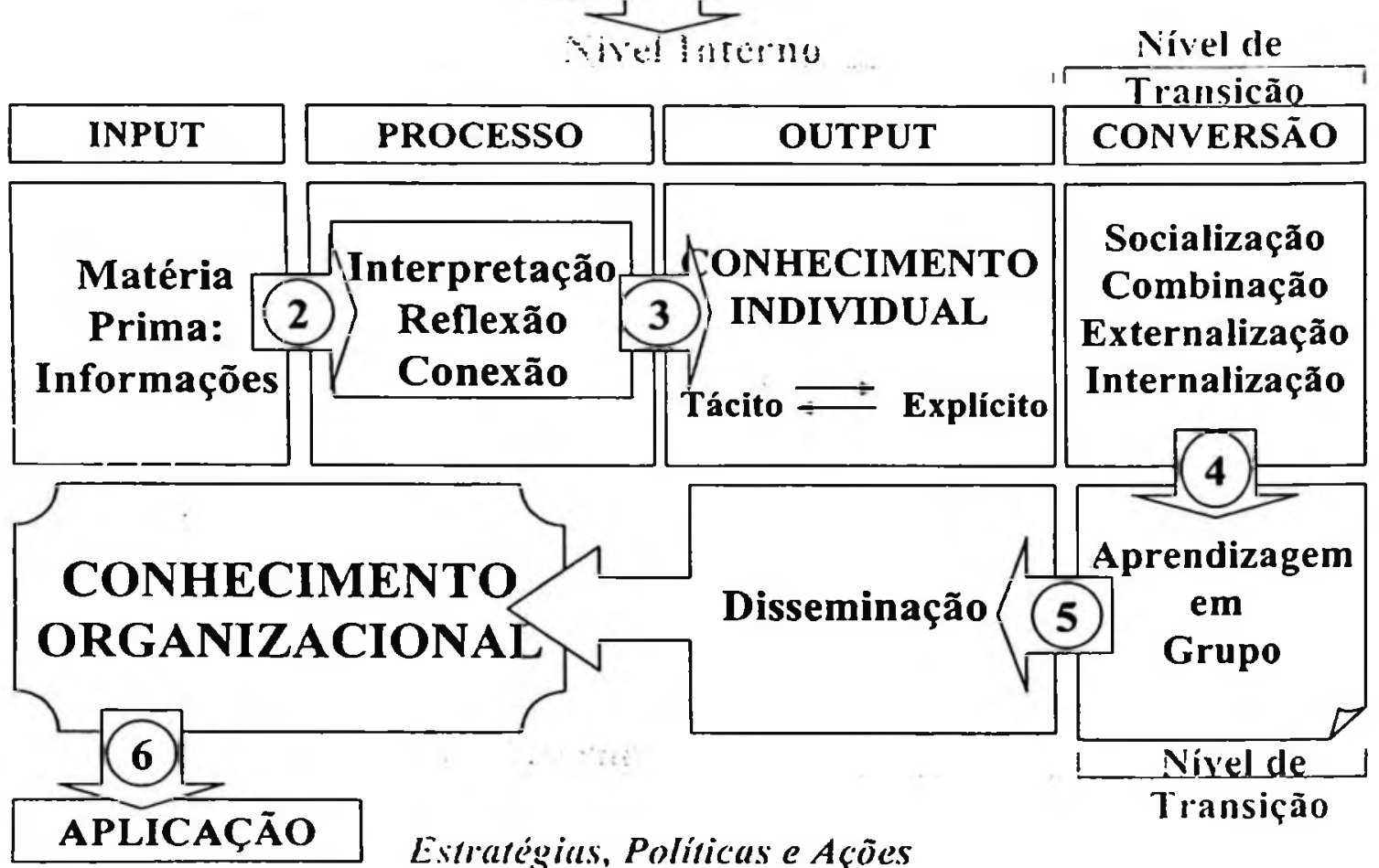

Figura 14: Do conhecimento individual ao conhecimento organizacional.

Fonte: Autora, com base na literatura estudada.

A informação, matéria prima para a formação do conhecimento, está no nível externo do indivíduo, podendo ser proveniente do ambiente interno ou do ambiente externo à organização. O processo de transformação da informação em conhecimento ocorre no nível 
interno do indivíduo, envolvendo reflexão, interpretação e conexão para posterior experimentação prática dentro de um determinado contexto.

O esforço da organização em reunir e disponibilizar informações não garante o acesso e o processamento por parte das pessoas. Porém, é imprescindível que ações de estímulo ao acesso e ações de indução ao processamento de informações sejam implementadas, num esforço de transformar essas práticas em atitudes naturais das pessoas, incorporadas na cultura organizacional.

O conhecimento individual precisa ser transferido para outros indivíduos e grupos para se transformar em conhecimento organizacional, que está no nível externo do indivíduo. Para ser transferido, o conhecimento deve ser exteriorizado pelos seus detentores e internalizado pelos que não o possuem, principalmente o conhecimento tácito, por ser de dificil imitação pela concorrência. Como mencionado anteriormente, a transformação do conhecimento individual em conhecimento organizacional ocorre por meio dos quatro modos de conversão: socialização, externalização, internalização e combinação. Esse processo ocorre em um nível de transição localizado entre o nivel interno e o nível externo do indivíduo.

O processo de transferência do conhecimento individual pode ocorrer de pessoa para pessoa, de pessoa para grupos ou intra-grupo. As duas últimas formas são mais eficientes para dar mais agilidade na disseminação do conhecimento. É pela disseminação do conhecimento individual para pessoas, para grupos, para áreas, para unidades, ou seja, para todos os níveis da organização, que se forma o conhecimento organizacional.

O manancial de conhecimento que a organização formou, por sua vez, contribui com o fornecimento de informações para o desenvolvimento de mais conhecimentos individuais, compondo um círculo virtuoso semelhante ao processo de alimentação mútua, que ocorre entre as competências individuais e as organizacionais (Figura 5, p. 19).

A organização deve alinhar estratégias, políticas e ações aos objetivos organizacionais. Deve criar estruturas adequadas, ambientes propicios e estimular relações favoráveis aos processos de formação do conhecimento necessário para viabilizar a concretização de seus objetivos.

Trabalho perseverante e visão de longo prazo são necessários para que os processos de formação do conhecimento individual e sua transformação em conhecimento organizacional completem o círculo e se alimentem mutuamente. 
O propósito da gestão do conhecimento é implementar ações com o objetivo de alimentar as bases do conhecimento organizacional, promovendo a concretização do processo descrito na Figura 14 (p. 82), o qual fundamenta o modelo conceitual de sistema de gestão do conhecimento apresentado no próximo item.

O modelo ora concebido contempla ações gerenciais para as várias etapas que compõem o percurso do conhecimento, desde a sua criação no indivíduo até formação do conhecimento organizacional.

\subsubsection{Sistema de GC para o desenvolvimento de competências}

O modelo conceitual do sistema de gestão do conhecimento, elaborado a partir da análise da literatura abordada na fase teórica do presente trabalho, contempla as seis etapas do percurso do conhecimento representado na Figura 14 (p. 82):

1) criação de significado, ou a visão compartilhada dos objetivos de se desenvolver ou criar um conhecimento,

2) provimento de informações,

3) indução ao processamento interno para a formação do conhecimento individual,

4) conversão do conhecimento individual para a aprendizagem em grupo,

5) disseminação do conhecimento para outros níveis da organização e

6) aplicação prática do conhecimento.

$\mathrm{O}$ modelo conceitual de GC concentra as ações gerenciais correspondentes às seis etapas descritas acima. Essas ações estão estruturalmente organizadas em quatro esferas, dispostas em torno de um núcleo (Figura 15). 


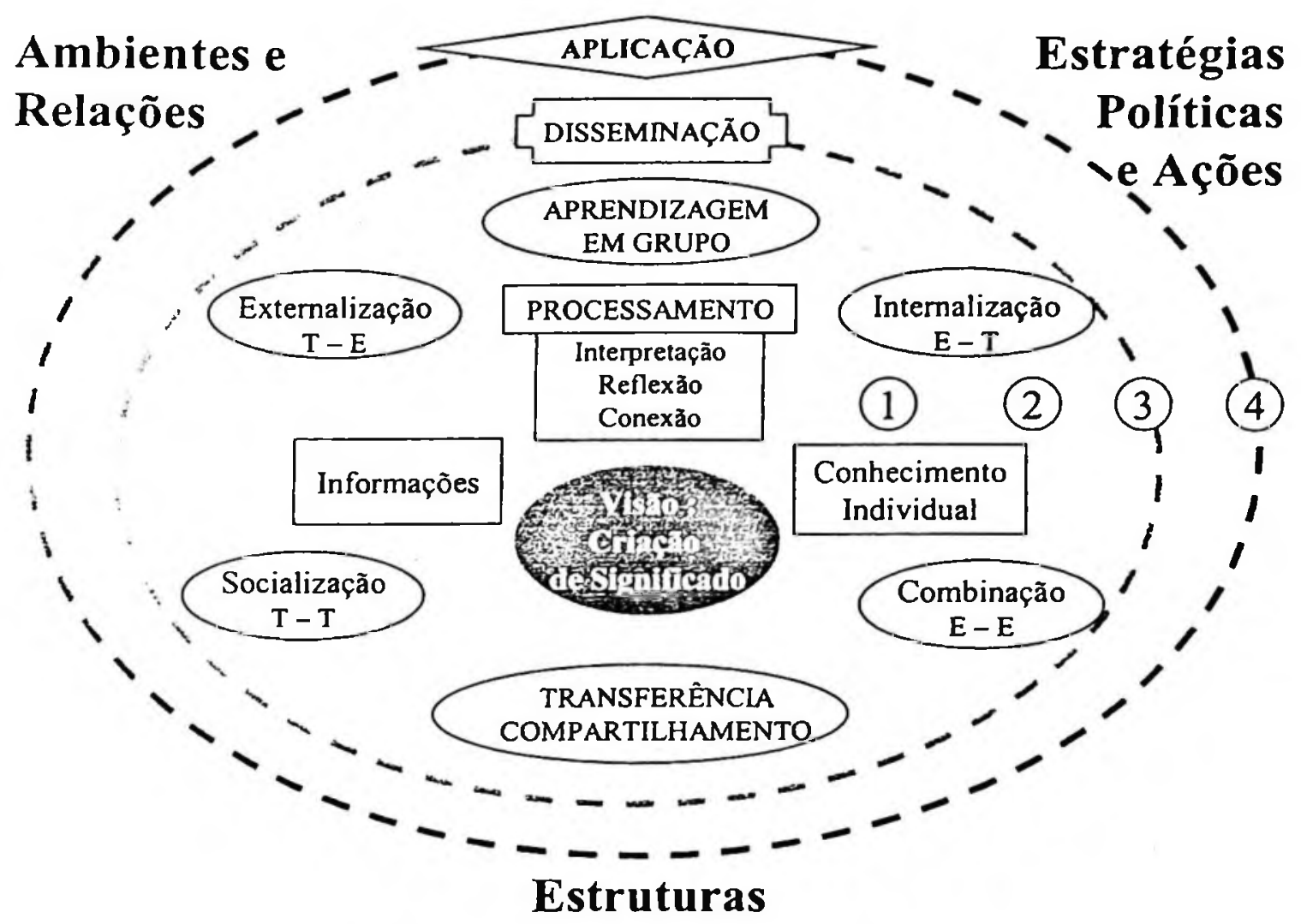

Figura 15: Modelo Conceitual de um sistema de gestão do conhecimento.

Fonte: Autora, com base na literatura estudada.

As esferas da gestão do conhecimento representam os níveis em que as ações gerenciais devem ser implementadas para a concretização dos processos de formação do conhecimento, dentro do contexto organizacional. $O$ ideal é que nesse contexto, o ambiente, as relações, as estratégias, as ações gerenciais, as políticas e estruturas e objetivos organizacionais estejam alinhados de maneira a favorecer as práticas de gestão do conhecimento.

O núcleo representa a visão compartilhada. Nele concentram-se as ações de promoção do compartilhamento da visão do conhecimento a ser desenvolvido ou criado. É preciso criar significados, isso quer dizer que as pessoas devem ser comunicadas sobre os conhecimentos a serem desenvolvidos. As pessoas devem compreender as razões da necessidade desse desenvolvimento para que se comprometam e concentrem esforços para o alcance dos objetivos.

A primeira esfera representa um processo de produção interna: a criação do conhecimento individual. Envolve o fornecimento de matéria prima por meio de ações para estimular o fluxo de informações, facilitar a comunicação entre as pessoas e o acesso a redes 
de relacionamentos, bibliotecas, bancos de dados, internet etc. Envolve também ações de estímulo à reflexão, interpretação e conexão das informações para a criação de conceitos.

A segunda esfera concentra ações para estimular as quatro formas de conversão do conhecimento individual: a externalização (T-E: conversão do conhecimento tácito para explícito), a internalização (E-T: conversão do conhecimento explícito para tácito), combinação (E-E: conversão do conhecimento explícito para explícito) e a socialização (T-T: conversão do conhecimento tácito para tácito). O objetivo dessas ações é fomentar a transferência e compartilhamento do conhecimento existente, a criação de novos conhecimentos e promover o aprendizado em grupo. Essas ações devem promover contatos entre as pessoas, gerenciar conversas, proporcionar condições para a combinação dos modelos mentais, intercâmbio de experiências e práticas.

Na terceira esfera ocorre a disseminação do conhecimento. É preciso criar uma base de acesso ao conhecimento organizacional para posterior disseminação. Dependendo da estratégia adotada pela organização, a base pode conter 0 registro do conhecimento codificado, pronto para ser reutilizado (people-to-document) ou pode registrar o mapa das fontes, trazendo informações sobre as pessoas que possuem determinados conhecimentos, habilidades ou experiências em uma determinada situação (person-to-person). A disseminação pode ocorrer ou pelo acesso à base de conhecimento codificado, ou através do contato entre as pessoas.

A quarta esfera foca as ações de fomento à utilização coletiva do conhecimento organizacional. Ações de estímulo à aplicação do conhecimento para a criação de soluções de problemas e para o desenvolvimento ou inovação de produtos. Envolve apoio na exposição a riscos e tolerância a erros.

Foi com base nesse modelo conceitual que a empresa estudada implementou seu sistema de gestão do conhecimento para o desenvolvimento de competências individuais e organizacionais. No capitulo seguinte, serão apresentados os dados coletados na fase empirica. 


\section{CAPÍTULO 4}

APRESENTAÇÃO DOS DADOS DA PESQUISA DE CAMPO 


\subsection{Contextualização:}

O estudo de caso é uma investigação que estuda um fenômeno contemporâneo dentro do seu contexto real (YIN, 2001). Por essa razão, a descrição do contexto em que a pesquisa se desenvolve é o segundo objetivo especifico do trabalho.

Para atender ao objetivo específico de analisar o contexto em que a pesquisa se desenvolve, os dados apresentados a seguir descrevem o ambiente em que se situa a unidade de análise do presente estudo, em dois níveis. O segmento de assessoria e consultoria jurídica compõe o contexto externo e a empresa estudada compõe o contexto interno.

\subsubsection{O Segmento de assessoria e consultoria jurídica}

Evidências coletadas através da análise dos seguintes documentos:

- análise setorial publicada pela Gazeta Mercantil em 2002 (a mais recente);

- arquivo e matérias publicadas em jornais e revistas e livros sobre o setor jurídico;

- código de ética da OAB - Ordem dos Advogados do Brasil

As empresas nacionais atuantes no segmento jurídico são, em geral, pequenas e familiares. Pesquisas indicam que poucas se desenvolveram a ponto de serem consideradas grandes empresas. Não passa de dez o número de empresas que podem ser consideradas grandes no mercado nacional (Quadro 9).

A análise setorial da Gazeta Mercantil revelou a existência de 4990 empresas de advocacia registradas na seccional da OAB-SP. Desse total, $97,27 \%$ tinham até 5 advogados. Apenas 18 entre elas tinham em seu quadro mais de 20 advogados. Isso significa $0,36 \%$ do total. Esse percentual é ainda menor quando se fala em empresas com mais de 100 advogados (BRUM, 2002).

Pelos resultados da pesquisa The Latin Lawyer, realizada em 2004 (Quadro 9), apenas nove empresas brasileiras contam com mais de 100 advogados. Segundo informações da análise setorial da Gazeta Mercantil (BRUM, 2002), essas empresas apresentam uma trajetória de mais de 40 anos desde sua fundação. No momento da coleta de dados, a empresa estudada contava com 110 advogados. 


\begin{tabular}{|c|l|c|c|}
\hline & SOCIEDADE & $\begin{array}{c}\text { N DE } \\
\text { ADVOGADOS }\end{array}$ & $\begin{array}{c}\text { No }^{\circ} \text { DE } \\
\text { SÓCIOS }\end{array}$ \\
\hline 1 & Demarest e Almeida Advogados & 365 & 79 \\
\hline 2 & Tozzini Freire Teixeira e Silva Advogados & 346 & 61 \\
\hline 3 & Pinheiro Neto Advogados & 325 & 61 \\
\hline 4 & Machado, Meyer, Sendacz e Opice Advogados & 293 & 32 \\
\hline 5 & Veirano \& Advogados Associados & 223 & 25 \\
\hline 6 & Mattos Filho, Veiga Filho, Marrey Jr e Quiroga Advogados & 146 & 25 \\
\hline 7 & Trench, Rossi e Watanabe Advogados (Assoc. with Baker McKenzie) & 138 & 27 \\
\hline 8 & Barbosa Müssnich \& Aragão & 129 & 15 \\
\hline 9 & Leite Tosto e Barros Advogados Associados & 104 & 11 \\
\hline 10 & Gouvêa Vieira Advogados & 95 & 14 \\
\hline
\end{tabular}

Quadro 9: Classificação das bancas de advocacia no Brasil - Latin Lawyer 2004

Fonte: Revista Consultor Jurídico de 19 de julho de 2004 - acesso em 15/12/2004 http://conjur.uol.com.br/textos/251165/

Conforme expõe a Análise Setorial da Gazeta Mercantil (BRUM, 2002), verifica-se um crescimento notável no segmento de serviços jurídicos nos últimos 10 anos. $\mathrm{O}$ fenômeno da globalização provocou profundas alterações no mercado, no perfil dos clientes, na demanda por esse tipo de serviços oferecendo novas ameaças e novas oportunidades.

O movimento de privatizações e internacionalização da economia brasileira trouxe muitas mudanças para as empresas do setor. $\mathrm{O}$ mercado passou a demandar experiências e conhecimentos legais mais aprofundados em Direito Empresarial, notadamente nos temas fusões e aquisições, concessão de serviços públicos e regulação de concorrência. Além disso, ocorreu ampliação significativa da demanda em outras regiões geográficas do pais e no exterior, diferentes do sudeste, onde se concentrava a maior parte da demanda até então. Esse fato provocou, também no segmento de serviços jurídicos, uma onda fusões e associações entre empresas brasileiras e entre empresas brasileiras e estrangeiras, para poderem ampliar a abrangência de atuação e atendimento local aos clientes. O fenômeno se verificou notadamente a partir do início do ano 2000 (BRUM, 2002).

Porém, muitas empresas, principalmente as de pequeno porte e gestão familiar, não se encontram estruturadas para lidar de maneira estratégica com as ameaças e capitalizar as 
oportunidades para o seu crescimento no novo cenário. (SELEM, 2003). Mesmo as empresas consideradas grandes, com mais de 100 advogados, até bem pouco tempo atrás, eram geridas por sócios com formação em direito. Apenas recentemente, começaram a se dar conta da necessidade de uma gestão estratégica de negócios e uma gestão estratégica de recursos humanos (BRUM, 2002). No final da década de 90, verificou-se uma movimentação das bancas de advocacia brasileiras para buscar administradores profissionais para a gestão dos seus negócios, para que os sócios se dedicassem ao exercício da advocacia (TEIXEIRA, 2003). Segundo a Análise Setorial da Gazeta Mercantil (BRUM, 2002), também no mercado intemacional, embora estejam melhor estruturadas, as empresas apresentam dificuldades de implementação de práticas modernas de gerenciamento.

Ações de marketing são extremamente limitadas pelo código de ética da Ordem dos Advogados do Brasil, órgão que regulamenta a atuação dessa categoria profissional e que, entre outras regras, proíbe propagandas, publicidade e outras ações voltadas à venda e atração de clientes, sugerindo uma atuação passiva por parte do profissional.

Os preceitos do código de ética são difundidos pelos docentes durante todo o curso de graduação, de forma que os profissionais já trazem interiorizados esses conceitos quando se habilitam a atuar no mercado. Isso dificulta a ação das empresas, que lutam para veicular seu nome e imagem, aumentar o número de clientes, sem, no entanto, ferir o código de ética da categoria profissional.

É consenso entre as empresas do segmento que o código de ética deve ser revisto e adequado ao contexto atual. A situação se torna mais crítica à medida que empresas internacionais, começam a se instalar no país aumentando a concorrência, conforme artigo de Lethbridge na Revista Exame de 04.08.2004.

Boranga; Lovro (1998), consultoras em administração de empresas jurídicas, falam sobre a resistência encontrada ao se falar em marketing para advogados, pois esse termo remete a eles conceitos de propaganda e vendas, objetos de restrição no código de ética da categoria. As consultoras sugerem algumas ações nesse sentido, não condenáveis sob o ponto de vista ético dos advogados, entre as quais destacam-se:

- trabalhar a imagem institucional pela participação em atividades de associações de classes e em atividades de lazer ligadas ao contexto jurídico e empresarial (clubes, associações culturais e beneficentes etc), por meio de publicação de 
artigos para jornais e revistas, contando inclusive com o suporte especializado de profissional da área jornalística (assessoria de imprensa);

- estabelecer e manter canais de comunicação e relacionamento com clientes, enviando correspondência do tipo boletins informativos, estimulando os contatos pessoais e realizando pesquisas para mensurar o grau de satisfação e expectativas dos clientes;

- definir posicionamento de mercado, analisar a concorrência e avaliar as próprias vantagens no mercado em relação a ela e

- estabelecer metas e planos para alcançá-las.

Já se pode verificar que as grandes empresas do setor se mobilizam adotando essas ações ou parte delas.

\subsubsection{A empresa estudada:}

Evidências coletadas através da análise dos seguintes documentos:

- slides de apresentação da empresa,

- cd room institucional,

- relatórios de headcount,

- apresentações do programa de integração de novos colaboradores,

- materiais produzidos no workshop de apresentação e consolidação do modelo de gestão por competências e

- documentos de divulgação da missão, visão de futuro e objetivos organizacionais.

Por questões de confidencialidade, não será revelado o nome da empresa estudada. Sua constituição envolve seis unidades de negócios em diferentes cidades brasileiras. No momento da coleta, contava com aproximadamente 300 colaboradores, dos quais $65 \%$ integram as áreas técnicas (consultoria e assessoria) e $35 \%$ integram as áreas de gestão administrativa do negócio (administrativa, financeira, tecnologia e gestão de informações, marketing e recursos humanos). Mantém parcerias de negócios espalhadas pelo pais, que ampliam sua atuação em todo o território nacional. 
A estrutura organizacional tende para a horizontalização, apresentando poucos níveis hierárquicos:

- responsável Corporativo

- responsável por Unidade de Negócios

- responsável por Área de Negócios

- coordenadores de Equipes (em áreas mais complexas com equipes numerosas)

- equipes

A representação gráfica da estrutura adotada pela empresa foge intencionalmente do tradicional modelo de organograma, conforme ilustra a Figura 16, que apresenta um modelo representativo da estrutura da empresa.

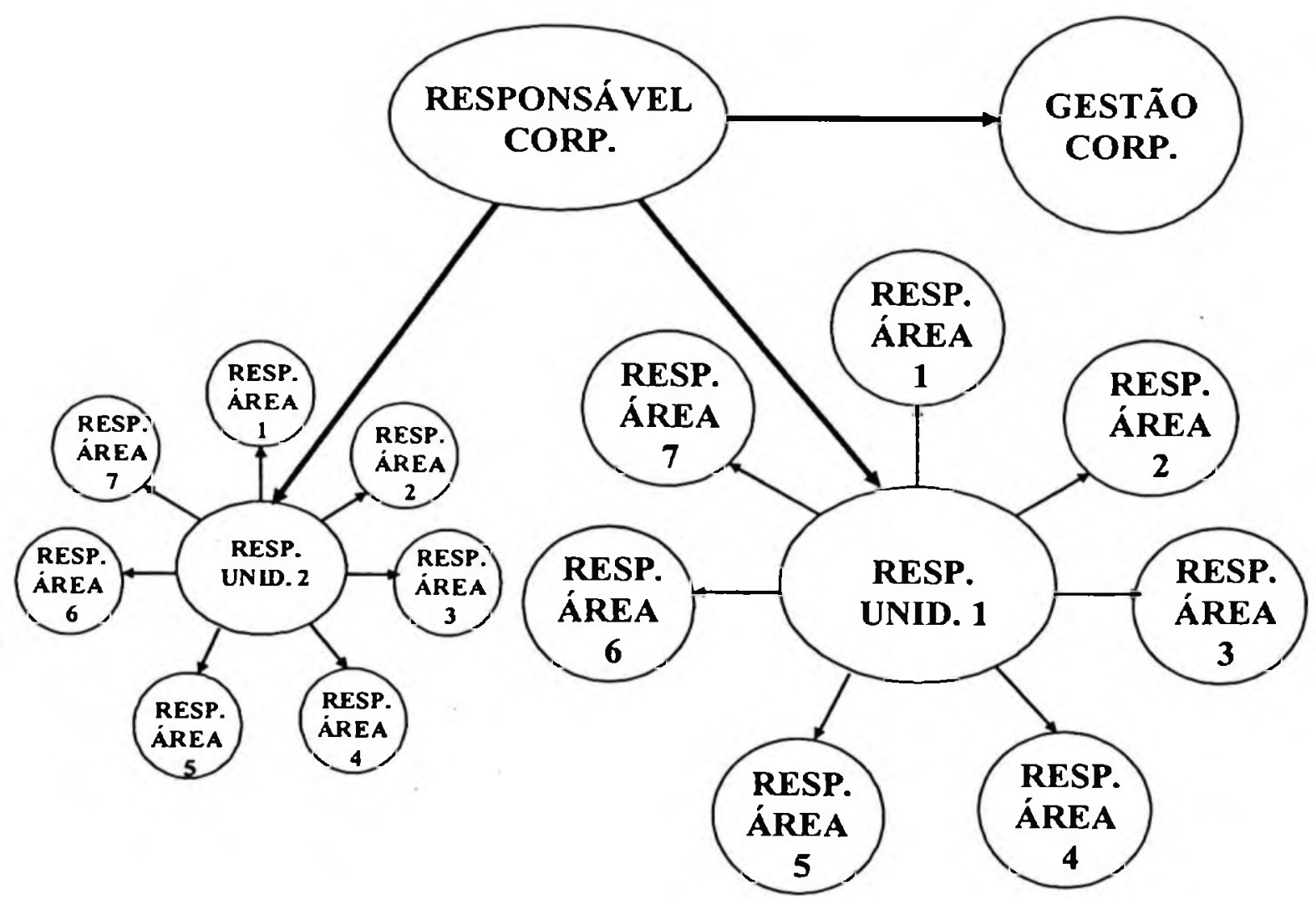

Figura 16: Modelo representativo da estrutura organizacional da empresa estudada Fonte: Adaptação do modelo de estrutura organizacional da empresa estudada

Com pouco mais de 15 anos de existência, a empresa vem registrando excelente índice de crescimento, principalmente nos últimos 5 anos. Com base nos dados divulgados na 
Análise Setorial da Gazeta Mercantil (BRUM, 2002), a empresa está entre as dez maiores empresas nacionais do segmento. Segundo informações do seu setor de comunicações, para fazer parte da pesquisa The Latin Lawyer, as organizações devem possuir pelo menos uma unidade de negócios em outro país da América Latina, o que faz parte dos planos da empresa estudada.

Seus objetivos de negócios envolvem conquistar degraus no ranking das maiores empresas nacionais, prestando serviços processuais e consultivos em todas as áreas do direito, sendo reconhecidos por oferecer serviços com qualidade, criatividade e rapidez.

A estratégia para que as metas estabelecidas fossem atingidas consistia em envolver um número maior de profissionais nas atividades que voltadas ao crescimento do negócio. Em outras palavras, ampliar a força voltada para o mercado, que até então se concentrava em uma pequena equipe da alta gestão coordenada pelo sócio-fundador.

Reconheceu-se a necessidade da implementação de estratégias de manutenção e estratégias de desenvolvimento. As estratégias de manutenção envolvem ações para consolidar a imagem da empresa junto aos clientes atuais e estreitar o relacionamento para promover a sua fidelização. As estratégias de desenvolvimento, por sua vez, visam fomentar o crescimento dos negócios para o alcance dos seus objetivos organizacionais de conquista de liderança pelo aumento da carteira de clientes e por operações de fusão e/ou aquisição. A empresa já realizou uma operação de aquisição e com freqüência os gestores administrativos são solicitados a participar de análises de outras empresas candidatas a processos de fusão e aquisição.

O reconhecimento da importância do papel das pessoas para o alcance dos objetivos de qualquer empresa, notadamente no setor de serviços de assessoria e consultoria, levou à necessidade de estruturar um novo modelo de gestão de pessoas. Esse modelo deveria estar adequado à nova visão e ao novo direcionamento dos negócios, bem como favorecer a implementação de estratégias e ações externamente orientadas (mercado e clientes). Os dois pontos principais das ações estratégicas se concentravam, portanto, nas áreas de marketing e recursos humanos.

Considerando a natureza do segmento de prestação de serviços de consultoria e assessoria jurídica, em que o conhecimento e as habilidades do indivíduo na solução de problemas é o que se oferece aos clientes, o sistema de gestão por competências foi escolhido como o mais adequado pela alta gestão. 
Obedecendo a seqüência da lógica que une as informações coletadas aos objetivos do trabalho (Apêndice 1, p. 168), a próxima seção apresentará os dados correspondentes ao terceiro objetivo específico, relativo à construção do padrão referencial que embasa o sistema de gestão por competências.

\subsection{A construção do sistema de gestão por competências}

Esta seção apresenta os dados coletados para atender os objetivos específicos relacionados à gestão por competências, anunciados no início deste estudo e resgatados a seguir:

- Analisar o processo de elaboração do padrão referencial de competências organizacionais e individuais.

- Analisar o processo de identificação das deficiências das competências, cujo desenvolvimento é o foco do programa estudado.

As evidências foram coletadas através da análise dos seguintes documentos:

- $\quad$ slides de apresentação do sistema de gestão por competências quando da sua concepção;

- materiais produzidos no workshop de apresentação e consolidação do sistema de gestão por competências;

- $\quad$ projeto do sistema de gestão por competências;

- documentos de divulgação da missão, visão de futuro e objetivos organizacionais;

Para a construção do sistema, o primeiro passo foi a criação de um padrão referencial que reunisse as competências necessárias para o alcance dos objetivos organizacionais e para a concretização da sua visão de futuro. Esse padrão referencial constitui a essência do sistema, fundamentando e direcionando as políticas e práticas envolvidas em todos os sub-sistemas de gestão de pessoas (seleção, treinamento e desenvolvimento, gestão do desempenho, gestão de carreira e remuneração). 
O projeto de elaboração do padrão referencial de competências envolveu várias etapas, relatadas a seguir.

1. Reuniões envolvendo a alta gestão para estruturação dos objetivos organizacionais e definição das estratégias necessárias para sua concretização.

2. Formação de um comitê de criação do padrão referencial de competências organizacionais e competências individuais. $O$ comitê foi composto por profissionais representantes de cada área das duas maiores unidades de negócios da empresa, integrantes da alta gerência, da gerência intermediária e de nível técnico, desde que estivessem na empresa há mais de três anos. Entendia-se que esse tempo era necessário, para que o profissional tivesse vivenciado e se envolvido com a cultura da organização.

O padrão referencial deveria contemplar o conjunto das competências necessárias para viabilizar a implementação das estratégias e o alcance dos objetivos. Deveria também estar em harmonia com a missão, visão e valores organizacionais. As seis competências organizacionais selecionadas para compor o padrão referencial são apresentadas no Quadro 10. Cada uma das seis competências foi desdobrada em grupos de competências individuais correspondentes.

\begin{tabular}{|c|}
\hline COMPETENCIAS ORGANIZACIONAIS \\
\hline Competências Técnicas Profissionais \\
\hline Competências Orientadas para Clientes (customer orientation) \\
\hline Competências de Liderança (orientadas para pessoas e resultados) \\
\hline Competências de Desenvolvimento de Negócios e Produtos \\
\hline Competências Gerenciais \\
\hline Competências comportamentais elementares \\
\hline
\end{tabular}

Quadro 10 - Padrão referencial de competências organizacionais e individuais Fonte: Autora, com base nos dados coletados.

3. Construído o padrão referencial de competências, a empresa realizou duas séries de workshops com o objetivo de divulgá-lo, envolver as pessoas com o seu conteúdo e despertar nelas a consciência para a necessidade do desenvolvimento daquelas competências. Nesses workshops foram realizados trabalhos para estimular a reflexão, buscando o 
estabelecimento de ligações das competências integrantes do padrão referencial com as estratégias e objetivos organizacionais. Esse trabalho objetivou promover o compartilhamento da visão da situação atual, da situação desejada no futuro e do caminho a ser percorrido entre uma e outra. Nesse caminho estavam incluídas as ações de desenvolvimento das competências.

4. Concomitantemente, a estrutura, as políticas e práticas dos setores de seleção, treinamento e desenvolvimento, gestão de carreira, gestão do desempenho e remuneração foram redefinidas e adequadas ao novo sistema de gestão de pessoas.

Cada competência do padrão referencial foi graduada de acordo com o nível de complexidade das atividades desenvolvidas pelos profissionais nos sete degraus da carreira, no sentido vertical. Isso significa que quanto mais o profissional ascende verticalmente na sua carreira, maior o grau de exigência das competências.

Os sete níveis da carreira são: advogado trainee, advogado júnior, advogado pleno, advogado sênior 1 , advogado sênior 2 , gerente 1 e gerente 2 .

Os passos seguintes envolveram ações voltadas à obtenção de maior compreensão da realidade da empresa, em termos de competências. A análise da situação real em relação ao padrão referencial definido.

\subsubsection{O padrão referencial e a situação (ideal $x$ real)}

Foi realizado um processo de mapeamento das competências existentes, com o objetivo de mensurar a distância entre o ideal desenhado no padrão referencial e a realidade dos profissionais da organização.

O processo envolveu auto-avaliações para que os próprios profissionais realizassem uma auto-análise comparando-se com o padrão referencial e estabelecessem quais competências atendiam e em quais se mostravam deficientes. Ao mesmo tempo, esses profissionais foram avaliados por seus superiores e por pelo menos três gestores estratégicos ligados a sua área de atuação.

Os resultados de cada avaliação foram cruzados, consolidados e discutidos com cada profissional em entrevistas de feedback. Dessa forma chegou-se a um consenso das deficiências a serem supridas em cada caso. 
Esse processo resultou em um mapa da situação da empresa, que direcionou as ações de formação das competências organizacionais. As maiores deficiências se concentravam nos grupos das competências de desenvolvimento de negócios e produtos e das competências orientadas para clientes e mercado, as quais são trabalhadas no programa ADC.

\subsection{Programa Academia de Desenvolvimento de Competências (ADC)}

Nesta seção são apresentados os dados coletados para a concretização do quarto objetivo específico apresentado no início do trabalho e reproduzido a seguir:

- Descrever o sistema de gestão do conhecimento aplicado para o desenvolvimento de competências no programa $\mathrm{ADC}$, com base no modelo conceitual elaborado.

Evidências coletadas através de observação participante e da análise dos seguintes documentos:

- projeto do programa ADC,

- relatórios das reuniões de compartilhamento,

- memorandos e correspondências internas,

- observação direta e participante dos eventos que integram o programa,

- resultados do processo de mapeamento e

- relatórios e memorandos sobre o assunto.

As competências individuais de desenvolvimento de negócios e produtos $\mathrm{e}$ as competências orientadas para clientes e mercado, trabalhadas no programa ADC, foram isoladas dos grupos das competências organizacionais e submetidas a uma ordem de priorização.

O critério de priorização das deficiências que deveriam receber as primeiras atenções foi o grau de impacto que elas poderiam causar à implementação das estratégias organizacionais e, conseqüentemente, ao alcance dos objetivos dentro do prazo estipulado para sua concretização.

As competências individuais consideradas prioritárias na visão da alta gestão e suas relações com as competências organizacionais estratégicas, são apresentadas no Quadro 11 . 
São as competências, cujo desenvolvimento é o objetivo do programa ADC, implementado pela empresa estudada.

\begin{tabular}{|c|l|}
\hline $\begin{array}{c}\text { Competências } \\
\text { organizacionais } \\
\text { estratégicas }\end{array}$ & \multicolumn{1}{c|}{$\begin{array}{c}\text { Competências individuais correspondentes focadas } \\
\text { pelo programa ADC }\end{array}$} \\
\hline $\begin{array}{c}\text { Competências de } \\
\text { Desenvolvimento } \\
\text { de Negócios e } \\
\text { Produtos }\end{array}$ & $-\begin{array}{l}\text { Conhecimento da empresa seus produtos, clientes e mercados. } \\
\text { Percepção, criatividade e realização (identificação de oportunidades para } \\
\text { criação de produtos e negócios, e conversão de oportunidades em negócios). } \\
\text { Habilidades de negociação. } \\
\text { Habilidades de comunicação da imagem institucional (auto-exposição e } \\
\text { oratória). }\end{array}$ \\
\hline $\begin{array}{c}\text { Competências } \\
\text { Orientadas para } \\
\text { Clientes e } \\
\text { Mercado }\end{array}$ & $-\begin{array}{l}\text { Qualidade de serviços (criatividade e rapidez na criação de soluções de } \\
\text { valor). } \\
\text { Excelência de relacionamento com clientes. }\end{array}$ \\
\hline
\end{tabular}

Quadro 11 - Competências organizacionais e individuais trabalhadas pela ADC

Fonte: Autora, com base nos dados coletados.

A seguir será descrito o processo de composição do programa ADC.

\subsubsection{Composição da Academia de Desenvolvimento de Competências-ADC}

O grupo é composto por profissionais-modelo (pessoas identificadas como detentoras das competências foco do programa), por profissionais em desenvolvimento (profissionais com potencial para desenvolver as competências organizacionais) e por profissionais convidados (profissionais com maturidade e experiência destacadas).

1) PROFISSIONAIS-MODELO: são considerados modelos os profissionais que:

- demonstram comprometimento com a profissão e com a empresa,

- têm senioridade e maturidade profissional,

- apresentam as competências consideradas estratégicas,

- têm alto nivel de conhecimento e experiências significativas que possam ser compartilhados e ensinados aos profissionais em desenvolvimento.

Três profissionais-modelo foram designados para integrar o programa no papel de orientadores. Esses profissionais, analisados com base no resultado do mapeamento das 
competências, foram considerados muito próximos do perfil definido pelo padrão referencial de competências da empresa. Também são reconhecidos como referenciais pela equipe local.

O conteúdo do programa, bem como seus objetivos foram apresentados e discutidos com os profissionais selecionados como orientadores. Para criar um ambiente favorável ao desenvolvimento das competências, esses profissionais receberam orientações detalhadas sobre como atuar como desenvolvedores. As orientações abrangeram a importância do relacionamento pessoal, do estímulo ao risco e da tolerância a erros. Buscou-se criar a consciência da necessidade de encorajamento, do clima de informalidade e liberdade para exposição de idéias, opiniões dúvidas e deficiências. A disponibilidade para orientações e auxílios nas situaçōes de dificuldade também foi colocada como essencial para o sucesso do programa. Os orientadores são acompanhados e apoiados por profissional especializado em treinamento e desenvolvimento nas suas atividades de orientadores.

2) PROFISSIONAIS EM DESENVOLVIMENTO: são profissionais em nível intermediário da carreira profissional, orientados pelos profissionais modelos no processo de desenvolvimento de suas competências.

Foram convidados a participar do programa três profissionais com experiência entre quatro e cinco anos e idade entre 25 e 29 anos. Essas pessoas foram selecionadas com base nos resultados das avaliações semestrais, por apresentarem potencial para o desenvolvimento das competências eleitas como estratégicas para o negócio da sociedade (Quadro 11, p. 98).

3) PROFISSIONAIS CONVIDADOS: profissionais com maturidade e experiência destacadas para contribuir com o enriquecimento das atividades de compartilhamento de conhecimentos e experiências do programa.

Espera-se que os profissionais em desenvolvimento adquiram as competências de desenvolvimento de negócios e as competências profissionais orientadas para mercado e clientes e que estejam preparados para atuarem como orientadores, no prazo máximo de 24 meses. Após esse prazo o número de orientadores dobrará, assim como o número de orientados. Dessa forma, o programa pretende disseminar conhecimentos criados no grupo e formar o conhecimento organizacional.

Ao receberem as orientações de como seriam realizadas as atividades de desenvolvimento, demonstraram interesse imediato e comprometeram-se com os objetivos do programa. Na primeira reunião de compartilhamento, em depoimento escrito de próprio punho sobre suas expectativas em relação à empresa e às atividades, expuseram seu 
entusiasmo e comprometimento com o auto-desenvolvimento e com os objetivos do programa.

Cada um teve a oportunidade de escolher o profissional para seu orientador, segundo suas afinidades. Os três discutiram e entraram em acordo sobre suas escolhas.

\subsubsection{Etapas do programa - aplicação do modelo conceitual}

Para facilitar a compreensão da aplicação do modelo conceitual de sistema de gestão do conhecimento para o desenvolvimento de competências na empresa estudada, a Figura 15 (exibida na p. 85), com a sua representação gráfica é reapresentada a seguir:



Figura 15: Modelo conceitual do sistema de gestão do conhecimento Fonte: Autora, com base na literatura pesquisada 
As evidências foram coletadas pela análise do projeto ADC, documentos e registros em arquivo relacionados com o programa.

O Núcleo concentra ações para o compartilhamento da visão do conhecimento, ou das competências a serem desenvolvidas, bem como da importância do seu desenvolvimento para a implementação de estratégias para o alcance dos objetivos organizacionais. $O$ compartilhamento da visão foi o foco dos workshops citados na etapa 3 da criação do sistema de gestão por competências (p. 95). O projeto e os slides utilizados nesses eventos evidenciam conteúdo e a forma dos trabalhos desenvolvidos (Quadro 12). O material pesquisado (slides, textos, dinâmicas etc.) evidencia um trabalho de maior profundidade com o grupo de lideranças em relação ao trabalho realizado com as equipes. A carga horária maior para o grupo de lideranças tanto no primeiro quanto no segundo ciclo de workshops reforça essa diferença.

\begin{tabular}{|l|l|}
\hline \multicolumn{1}{|c|}{ Primeiro ciclo: realizado em dezembro de 2002} \\
\hline Lideranças (16 horas) & \multicolumn{1}{c|}{ Temas abordados } \\
Equipes (8 horas) & $\begin{array}{l}\text { Contexto externo: } \\
\text { - mutações constantes, } \\
\text { - competição acirrada. } \\
\text { Contexto interno: }\end{array}$ \\
- Necessidades para enfrentar a complexidade, \\
- Como.enfrentar: recursos, estratégias e objetivos, \\
- A idéia do projeto de gestão por competências, \\
- Consolidação da missão, visão e valores \\
organizacionais.
\end{tabular}

Quadro 12: Estrutura dos workshops

Fonte: Autora, com base nos dados coletados. 
As ações para o compartilhamento da visão do conhecimento, ou das competências a serem desenvolvidas, continuaram a ser realizadas nos programas de integração de cada novo colaborador admitido na empresa após a realização dos workshops.

A primeira esfera concentra o processo de formação do conhecimento individual, que se inicia com o formecimento de informações, passando pelo processamento interno (interpretação, reflexão e conexão) por parte dos indivíduos, para a formação do seu conhecimento.

Nesta etapa, a ADC tem como objetivos:

- apresentar conceitos ligados às competências a serem desenvolvidas pelo programa (competências de desenvolvimento de negócios e competências orientadas para serviços), seguindo o estilo didático tradicional de apresentações em sala de aula.

- estimular a interpretação, a reflexão e a conexão das informações por meio de debates, discussões em grupo e atividades vivenciais.

O provimento de informações foi composto por dois módulos, um introdutório e um avançado. O módulo introdutório trabalhou conceitos de atendimento e relacionamento com clientes, padrão de qualidade de serviços a clientes, técnicas de apresentação, relações com a mídia, divulgação das áreas de serviços que compõem a empresa, dos produtos/ serviços que cada uma oferece, bem como das características/perfil dos clientes que cada uma atende. $O$ modulo avançado é composto pelas seguintes matérias: análise de mercado, análise organizacional, gestão empresarial, finanças, planejamento estratégico e técnicas e habilidades de consultoria.

O módulo introdutório foi ministrado por profissionais da empresa, de reconhecida maturidade e competência, incluindo gerentes e sócios. Para ministrar as matérias componentes do módulo avançado foi contratada uma empresa de consultoria especializada.

Os profissionais em desenvolvimento passaram pelo módulo introdutório pela primeira vez em julho de 2003 e uma segunda vez em julho de 2004, para reforço dos conceitos apresentados. Quanto ao módulo avançado, no momento da coleta já haviam sido ministradas as aulas de técnicas e habilidades de consultoria, finanças e análise de mercado. As matérias que não tratam de mercado e clientes, como gestão empresarial, finanças e planejamento estratégico, tiveram como principal objetivo desenvolver nos participantes a compreensão do funcionamento de empresas, uma vez que estas constituem seu público-alvo. 
No que tange à provisão de informações para a formação do conhecimento individual, a unidade da empresa conta ainda com um departamento que concentra todas as informações e estratégias adotadas na condução de serviços processuais prestados aos clientes. Esse departamento constitui uma base de conhecimentos técnicos (legais) da empresa.

Os profissionais têm acesso direto à internet. Contam com uma biblioteca local com aproximadamente 2000 obras, a maior parte no campo do direito, possuindo também obras no campo da filosofia, administração e outros. O acervo inclui publicações diversas, revistas e periódicos. Adicionalmente o setor de comunicações produz clippings diários com o resumo das notícias relacionadas ao negócio, publicadas nos principais jornais do país.

A segunda esfera concentra ações de fomento à conversão do conhecimento individual para transferência e compartilhamento, principalmente do que se refere ao conhecimento tácito. É constituída por dois eventos: reuniões quinzenais e atividades práticas. Teve início em fevereiro/2004.

As reuniões quinzenais têm como objetivo oferecer condições para discussões e troca de conhecimentos e experiências entre os integrantes do grupo. Outros profissionais experientes, diferentes dos orientadores, são especialmente convidados para contribuir com apresentação de casos que enriqueçam o aprendizado dos profissionais em desenvolvimento.

As situações relatadas e discutidas nas reuniões, bem como informações sobre os responsáveis pelo relato são disponibilizadas em rede para facilitar o acesso de outros profissionais e para reforçar os estímulos de compartilhamento de conhecimentos e experiências. A empresa não dispõe de tecnologia de informação ou softwares especificos para gestão do conhecimento. Utiliza um diretório na rede, com acesso disponibilizado aos integrantes do programa e convidados.

O espaço das reuniões quinzenais também é utilizado para criar. Os integrantes do programa nos últimos três meses empreenderam esforços na elaboração de um manual contendo o padrão de excelência em serviços e relacionamento com o cliente. Esse manual resultou de discussões e troca de informações realizadas nas reuniões durante o ano, além de pesquisa e análise de outros materiais sobre o assunto. No momento do encerramento da coleta de dados, o manual estava em fase de revisão final. Posteriormente o manual deve ser incorporado à base de conhecimento organizacional, além de servir como material didático no 
treinamento de outros profissionais a serem ministrados pelos próprios integrantes da ADC (orientadores e orientados).

Nas atividades práticas, cada profissional em desenvolvimento deve acompanhar o profissional designado para desempenhar o papel de orientador no seu desenvolvimento em:

- visitas de relacionamento com clientes,

- visitas de negociação,

- visitas de caráter prospectivo,

- outras visitas,

- apresentação de novos serviços,

- apresentações em geral e

- situações de atuação forense.

Nessas oportunidades, os profissionais em desenvolvimento devem observar a atuação de seus orientadores, refletir sobre os pontos percebidos como importantes contribuições para o seu desenvolvimento e fazer um relato dessas experiências nas reuniões quinzenais.

Os profissionais orientadores devem, além de atuar como exemplo, comentar suas demonstrações práticas, chamando a atenção dos profissionais em desenvolvimento sobre:

- a importância do preparo, da articulação de idéias, da objetividade, do poder de sintese, da capacidade de persuasão,

- as técnicas de apresentação e comunicação,

- os recursos para despertar o interesse e manter o envolvimento do cliente,

- as estratégias para conquistar o respeito e inspirar a confiança do cliente na sua capacidade de resolver seu problema.

- outros fatores relevantes de sua atuação.

Orientação cruzada: os profissionais em desenvolvimento poderão acompanhar outros profissionais, diferentes de seus orientadores, para enriquecer o seu aprendizado, devendo relatar suas experiências de acompanhamento, da mesma forma que o fazem quando acompanham seus orientadores.

A terceira esfera concentra as ações de disseminação do conhecimento. O projeto apresenta uma estimativa de que em um período de aproximadamente 24 meses os profissionais ora em desenvolvimento estejam em condições de atuar como orientadores. A 
atual equipe de orientação, composta por três profissionais, passaria a contar com seis pessoas trabalhando no desenvolvimento de mais seis (ou mais) profissionais.

Dessa forma poderão disseminar o conhecimento criado através das atividades da ADC, em amplitude cada vez maior.

Adicionalmente, os integrantes da ADC são estimulados a atuar como instrutores, ministrando treinamentos internos para outros profissionais menos experientes, transmitindo a outros grupos os conhecimentos adquiridos.

A quarta esfera foca ações de fomento à utilização do conhecimento. A utilização das competências em desenvolvimento é parte das atividades práticas da ADC. Os profissionais em desenvolvimento devem realizar suas próprias visitas a clientes e não clientes, desenvolver negócios, fazer apresentações da empresa, ministrar palestras sobre assuntos de sua área de atuação, conceder entrevistas, produzir artigos e atuar como instrutores internos.

Contatos e relações do corpo executivo são utilizados para viabilizar a atuação desses profissionais na concessão de palestras, cursos, aulas, entrevistas, etc. Os profissionais são estimulados, cobrados e avaliados semestralmente pelo seu desempenho na aplicação prática das competências trabalhadas na ADC.

São tomados como base para a avaliação, indicadores diretamente ligados aos resultados das práticas envolvendo as competências em desenvolvimento.

\subsection{Indicadores de desempenho do programa ADC}

Esta seção apresenta os dados coletados para atender o quinto objetivo específico que visa definir e analisar indicadores de desempenho do programa ADC.

As evidências foram coletadas através da análise de dos seguintes documentos:

- Documentos e registros em arquivo como: relatórios de avaliação de desempenho, relatórios comerciais e financeiros, resultados da pesquisa de satisfação de clientes e registros de comunicação institucional. 
Pelo projeto, os resultados do programa $\mathrm{ADC}$ deveriam estar refletidos em melhores resultados nos seguintes itens:

- no desempenho dos profissionais em desenvolvimento relativo às competências foco da ADC,

- nos seus contatos pessoais com clientes atuais e clientes em prospeç̧ão,

- nos índices de propostas de serviços emitidas,

- nos índices de propostas convertidas em negócios,

- no número de inserções na mídia (entrevistas e artigos),

- no número de palestras e apresentações concedidas,

- no resultado da pesquisa de satisfação de clientes.

O Quadro 13 resume as competências individuais focadas pelo programa e os indicadores selecionados para mensurar a eficácia do programa. Foram considerados dois períodos para a mensuração dos resultados acumulados: janeiro-outubro/2003 e janeirooutubro/2004.

Indicadores: evolução entre 2003 e 2004

- Resultados de avaliações de desempenho e desenvolvimento

- Quantidade de visitas a clientes atuais e em prospecção

- Quantidade de propostas emitidas

- Quantidade de propostas aceitas (convertidas em negócio)

- Quantidade de inserções na mídia

- Quantidade de Palestras e apresentações

- Resultado da pesquisa de satisfação de clientes

- Evolução de faturamento

Quadro 13 - Indicadores de desempenho do programa ADC

Fonte: Autora, com base nos dados coletados.

$\mathrm{Na}$ seqüência, serão apresentados os índices de evolução alcançados pelos três profissionais em desenvolvimento ( $\mathrm{P} 1, \mathrm{P} 2$, e $\mathrm{P} 3$ ), relativos a cada um dos indicadores de desempenho eleitos para avaliar o programa ADC. Lembrando que $\mathrm{TO}=$ janeiro a outubro/03 e Tl=janeiro a outubro/04. 


\begin{tabular}{|c|c|c|c|c|c|c|c|c|c|c|c|}
\hline \multicolumn{12}{|c|}{ P1 } \\
\hline $\begin{array}{c}\text { EVOLUÇĀO } \\
\text { DE TO } \\
\text { PARA T1 }\end{array}$ & \multicolumn{2}{|c|}{$\begin{array}{c}\text { VISITAS } \\
\text { CLIENTESE } \\
\text { PROSPECÇÓES }\end{array}$} & $\begin{array}{l}\text { PROPOSTAS } \\
\text { EMITIDAS }\end{array}$ & \multicolumn{2}{|c|}{$\begin{array}{c}\text { PROPOSTAS } \\
\text { ACEITAS }\end{array}$} & \multicolumn{2}{|c|}{$\begin{array}{l}\text { FATURA- } \\
\text { MENTO }\end{array}$} & \multicolumn{2}{|c|}{$\begin{array}{l}\text { INSERÇOES } \\
\text { NA MIDIA }\end{array}$} & $\begin{array}{l}\text { PALESTRAS } \\
\text { SEMINARIOS E } \\
\text { APRES. EM } \\
\text { GERAL }\end{array}$ & $\begin{array}{l}\text { PESQ. DE } \\
\text { SATISF. DE } \\
\text { CLIENTES }\end{array}$ \\
\hline$\%$ & \multicolumn{2}{|l|}{118,2} & 128,6 & \multicolumn{2}{|r|}{700,0} & \multicolumn{2}{|c|}{90,4} & \multicolumn{2}{|c|}{100,0} & 250,0 & - \\
\hline$N^{0} D E X$ & \multicolumn{2}{|l|}{2,2} & 2,3 & \multicolumn{2}{|r|}{8,0} & \multicolumn{2}{|c|}{1,9} & \multicolumn{2}{|c|}{2,0} & 3,5 & Satisfeitos \\
\hline \multicolumn{12}{|c|}{ AVALIAÇĀO DE DESEMPENHO } \\
\hline \multicolumn{12}{|c|}{ restriçð̄es (4) Atende (5) Supera parcialmente (6) Supera } \\
\hline \multicolumn{2}{|c|}{ Período } & \multicolumn{4}{|c|}{$\begin{array}{l}\text { Desenvolvimento de } \\
\text { Negócios e Produtos }\end{array}$} & \multicolumn{3}{|c|}{$\begin{array}{c}\text { Orientação } \\
\text { para Clientes }\end{array}$} & \multicolumn{3}{|c|}{ Média } \\
\hline \multicolumn{2}{|c|}{ Média: jan-out/03 } & \multicolumn{4}{|c|}{3,4} & \multicolumn{3}{|c|}{3,5} & \multicolumn{3}{|c|}{3,45} \\
\hline \multicolumn{2}{|c|}{ Média: jan-out /04 } & \multicolumn{4}{|c|}{4,8} & \multicolumn{3}{|c|}{5} & \multicolumn{3}{|c|}{4,9} \\
\hline \multicolumn{12}{|c|}{ PROMOÇÕES POR DESENVOLVIMENTO E DESEMPENHO } \\
\hline Adv. Traine & Adv. J & únior & Adv. Ple & & Adv. Sê & ênior 1 & & v. Se & ior 2 & Gerente 1 & Gerente 2 \\
\hline & & & fev/04 & & $\mathrm{jul} / 0$ & & & & & & \\
\hline & & & & & P2 & & & & & & \\
\hline $\begin{array}{l}\text { EVOLUÇĀO } \\
\text { DE TO } \\
\text { PARA T1 }\end{array}$ & $\begin{array}{c}\text { VISITAS } \\
\text { CLIENTES } \\
\text { PROS- } \\
\text { PECÇÓES }\end{array}$ & E & $\begin{array}{l}\text { ROPOSTAS } \\
\text { EMITIDAS }\end{array}$ & $\begin{array}{r}\text { PRO } \\
\text { AC }\end{array}$ & $\begin{array}{l}\text { PPOSTAS } \\
\text { CEITAS }\end{array}$ & $\begin{array}{l}\text { FATUR } \\
\text { MENT }\end{array}$ & & $\begin{array}{r}\text { INSE } \\
\text { NA }\end{array}$ & ÇŌES & $\begin{array}{l}\text { PALESTRAS } \\
\text { SEMINÁRIOS E } \\
\text { APRES. EM } \\
\text { GERAL }\end{array}$ & $\begin{array}{l}\text { PESQ. DE } \\
\text { SATISF. DE } \\
\text { CLIENTES }\end{array}$ \\
\hline$\%$ & 154,2 & & 25,0 & & 100,0 & 19,0 & & & & 150,0 & Satisfeitos \\
\hline$N^{\circ}$ DE $X$ & 2,5 & & 1,3 & & 2,0 & 1,2 & & & & 2,5 & Satisfeitos \\
\hline & & $\overline{\text { VALI }}$ & AÇÃO DE & $\overline{\mathrm{DES}}$ & SENVOLI & VIMEN & $\mathrm{TOE}$ & $\mathrm{DE}$ & EMPE & VHO & \\
\hline Escala: (1) Nã & o aplicável & (2) $\mathrm{N}$ & lão atende (3) & Ater & nde com re & estriçð̄es & (4) & Atend & (5) $\mathrm{S}$ & upera parcialment & e (6) Supera \\
\hline Períoc & & $\begin{array}{l}\text { Des } \\
\text { Neg }\end{array}$ & $\begin{array}{l}\text { envolvimen } \\
\text { ócios e Pro }\end{array}$ & $\begin{array}{l}\text { ito d } \\
\text { dutc }\end{array}$ & & $\begin{aligned} \text {-ientaçã } \\
\text { Clien }\end{aligned}$ & & & & Média & \\
\hline Média: jan- & -out/03 & & 3,4 & & & 4 & & & $\cdot$ & 3,7 & \\
\hline Média: jan- & out $/ 04$ & & 4,5 & & & 5,2 & & & & 4,85 & \\
\hline & PR & DMO & ÇÕES POR & DE & SENVOL & LVIMEI & JTO & E D & SEMF & ENHO & \\
\hline Adv. Trainee & Adv. Ji & nior & Adv. Plen & & Adv. Sêr & nior 1 & Ad & V. Sê & or 2 & Gerente 1 & Gerente 2 \\
\hline & & & & & jan/0 & & & & & & \\
\hline
\end{tabular}

Quadro 14: Índice de evolução dos indicadores definidos para a ADC (continua)

Fonte: Autora 


\begin{tabular}{|c|c|c|c|c|c|c|c|c|c|c|c|}
\hline \multicolumn{12}{|c|}{ P3 } \\
\hline $\begin{array}{c}\text { EVOLUÇĀO } \\
\text { DE TO } \\
\text { PARA T1 }\end{array}$ & \multicolumn{3}{|c|}{$\begin{array}{l}\text { VISITAS } \\
\text { CLIENTES E } \\
\text { PROS- } \\
\text { PECÇÕES }\end{array}$} & \multicolumn{2}{|c|}{$\begin{array}{l}\text { PROPOSTAS } \\
\text { EMITIDAS }\end{array}$} & \multicolumn{2}{|c|}{$\begin{array}{c}\text { PROPOSTAS } \\
\text { ACEITAS }\end{array}$} & $\begin{array}{l}\text { FATURA- } \\
\text { MENTO }\end{array}$ & $\begin{array}{c}\text { INSERÇŌES } \\
\text { NA MIDIA }\end{array}$ & $\begin{array}{l}\text { PALESTRAS } \\
\text { SEMINÁRIOS E } \\
\text { APRES. EM } \\
\text { GERAL }\end{array}$ & \begin{tabular}{|l} 
PESQ. DE \\
SATISF. DE \\
CLIENTES
\end{tabular} \\
\hline$\%$ & \multicolumn{3}{|c|}{300,0} & \multicolumn{2}{|c|}{$1.200,0$} & \multicolumn{2}{|c|}{4,0} & 55,3 & 1 & 0 & 1 Insatisf. \\
\hline$N^{0}$ DE $X$ & \multicolumn{3}{|c|}{4,0} & \multicolumn{2}{|c|}{13,0} & \multicolumn{2}{|c|}{4,0} & 1,6 & 1,0 & 0,0 & Satisfeitos \\
\hline \multicolumn{12}{|c|}{ AVALIAÇĂO DE DESENVOLVIMENTO E DESEMPENHO } \\
\hline \multicolumn{12}{|c|}{ Escala: (1) Nào aplicável } \\
\hline \multicolumn{3}{|c|}{ Período } & & \multicolumn{4}{|c|}{$\begin{array}{l}\text { Desenvolvimento de } \\
\text { Negócios e Produtos }\end{array}$} & \multicolumn{2}{|c|}{$\begin{array}{c}\text { Orientação para } \\
\text { Clientes. }\end{array}$} & \multicolumn{2}{|c|}{ Média } \\
\hline \multicolumn{3}{|c|}{ Média: jan-out/03 } & & \multicolumn{4}{|c|}{3,4} & \multicolumn{2}{|r|}{4} & \multicolumn{2}{|c|}{3,7} \\
\hline \multicolumn{3}{|c|}{ Média: jan-out $/ 04$} & & \multicolumn{4}{|c|}{4,5} & \multicolumn{2}{|r|}{4,75} & \multicolumn{2}{|c|}{4,6} \\
\hline \multicolumn{12}{|c|}{ PROMOÇÕES POR DESENVOLVIMENTO E DESEMPENHO } \\
\hline \multirow{2}{*}{\multicolumn{2}{|c|}{ Adv. Trainee }} & \multirow{2}{*}{\multicolumn{3}{|c|}{ Adv. Júnior }} & \multirow{2}{*}{\multicolumn{2}{|c|}{ Adv. Pleno }} & \multicolumn{2}{|c|}{ Adv. Sênior 1} & Adv. Sênior 2 & Gerente 1 & Gerente 2 \\
\hline & & & & & & & \multicolumn{2}{|c|}{ ago/04 } & & & \\
\hline
\end{tabular}

Quadro 14: Índice de evolução dos indicadores definidos para a ADC (continuação)

Fonte: Autora

As promoções por desenvolvimento ou desempenho foram adicionadas ao quadro de indicadores, porque cada vez que elas ocorrem, indiretamente causam impactos no resultado dos demais indicadores. Isso porque a cada degrau da carreira, representada por sete niveis (advogado trainee, advogado júnior, advogado pleno, advogado sênior 1, advogado sênior 2, gerente 1 e gerente 2), crescem as exigências em relação ao grau das competências referenciais.

\subsection{A percepção dos integrantes da ADC}

Além dos indicadores, foram levantadas as percepções dos integrantes da ADC sobre as contribuições do programa na evolução das competências dos profissionais em desenvolvimento e no progresso dos resultados como revelaram os indicadores.

Para essa finalidade foram realizadas entrevistas individuais focalizadas com os profissionais em desenvolvimento e entrevista coletiva com os profissionais-modelo 
(orientadores). Também foram coletados os depoimentos dos demais participantes convidados.

A realização das entrevistas individuais focalizadas com os profissionais em desenvolvimento teve como objetivo levantar suas percep̧̧ões quanto às contribuições do programa ADC no seu desenvolvimento e desempenho.

A entrevista coletiva com os profissionais-modelo teve por objetivo coletar suas percepções quanto ao papel do programa no desenvolvimento dos seus orientados.

Aos demais participantes foi solicitado um depoimento expondo suas impressões sobre as contribuições do programa para o desempenho e desenvolvimento dos participantes.

Explorando separadamente as percepções dos três grupos, buscou-se diminuir o grau de subjetividade dos depoimentos e, ao mesmo tempo complementar os resultados dos indicadores, dando maior consistência aos resultados da pesquisa.

\subsubsection{Relatório das entrevistas com os profissionais em desenvolvimento}

As entrevistas buscaram coletar as percepções dos profissionais em desenvolvimento, com relação a cada uma das etapas do programa $\mathrm{ADC}$, refletidas nas quatro esferas do modelo (Figura 15, p. 85).

O roteiro das entrevistas constou dos seguintes tópicos:

A. Contribuição das etapas do programa ADC no seu desempenho e desenvolvimento:

A1) provimento de informações ( $1^{a}$ esfera);

A2) compartilhamento de conhecimentos e experiências - aprendizado em grupo ( $2^{\mathrm{a}}$ esfera);

A3) a atividade de orientação como disseminação - $3^{\text {a }}$ esfera $e$

A4) incentivo à prática ( $4^{\mathrm{a}}$ esfera).

B. Avaliação geral do programa

A seguir serão apresentados os dados coletados nas entrevistas com os três profissionais em desenvolvimento (P1, P2 e P3), seguindo o roteiro acima, preparado 
previamente para essa finalidade. Os temas definidos no roteiro da entrevista foram discutidos com os entrevistados e suas respostas foram registradas pelo entrevistador. Depois disso os entrevistados foram solicitados a registrar o que haviam respondido. As anotações do entrevistador foram complementadas pelas anotações dos entrevistados. Desta forma buscouse evitar percepções tendenciosas por parte do entrevistador. As expressões em itálico são reproduções fieis de seus discursos.

OBS.: Não foi possivel realizar a entrevista com um dos profissionais em desenvolvimento em virtude de uma gravidez de risco, cujo parto ocorreu no mês de dezembro e a forçou a vários períodos de licença.

\section{A) Contribuição das etapas do programa ADC no seu desempenho e} desenvolvimento.

\section{A1) Provimento de informações ( $1^{2}$ esfera)}

P1: Para P1, essa etapa foi de grande importância, embora, na sua opinião, o conhecimento seja transmitido de forma mais mecanizada e o aprendizado ocorra de forma mais passiva, em comparação com as etapas subseqüentes. P1 declara em seu relato: tivemos a oportunidade de conhecer melhor as áreas e os produtos da empresa. Também pudemos ver de forma sistematizada e organizada muitas informações que já tinhamos ouvido ou intuido. Tivemos contato com métodos e sistemas e técnicas que são ferramentas necessárias na prática.

P2: Também P2 reconhece esta etapa como uma parte importante do programa declarando que é sempre um canal a mais de conhecimentos diferenciados no cotidiano do advogado. Precisamos de conhecimentos diferentes do nosso conhecimento especifico (legal), como informaçōes sobre conceitos contábeis, de marketing, sistemas, etc. Essas informaçōes ampliam a visão do todo e servem de base para a maior consistência nas atividades e aumenta o valor do serviço. 


\section{A2) Compartilhamento de conhecimentos e experiências - aprendizado em grupo ( $2^{x}$ esfera)}

P1: Segundo a percepção de P1, essa etapa é o cerne desse sistema, a oportunidade ideal para se treinar a exposição de idéias e técnicas de argumentação e retórica, onde a aquisição de conhecimento se dá de forma natural e espontânea.

\section{Sobre as reuniōes de compartilhamento}

Para P1, trata-se de um espaço de treinamento efetivo, como uma simulação. Em suas palavras uma excelente oportunidade de discutir assuntos novos, fora da minha área. Uma oportunidade para aprender discutindo, argumentando, questionando, sem estar envolvido diretamente nos casos, a nossa preocupação é apenas aprender com experiência dos outros e exercitar nossa criatividade.

\section{Acompanhamento dos orientadores em atividades práticas:}

Pl vê em sua orientadora um exemplo em todos os sentidos (profissionais e pessoais). Diz que a atividade de acompanhamento lhe proporcionou aprendizado sobre comprometimento com o cliente, sobre a necessidade da qualidade e da capacidade de propor soluções de maneira imediata. Para P1, foi uma oportunidade observar e analisar sua orientadora em situações reais sem ter $a$ pressão de corresponder às expectativas do clientes, que existe quando está realizando suas próprias atividades.

Acompanhamento de outros profissionais, diferentes de seus orientadores, em atividades práticas (orientação cruzada):

Para Pl é uma oportunidade impar de aprendizado e afirma: tenho plena certeza que a proximidade e a observação de profissionais do nivel dos orientadores, sem a conotação de competição, sabendo que eles estavam ali para nos auxiliar, foi extremamente importante.

P2: Para P2, trata-se de uma etapa que oferece oportunidades de conviver com outros profissionais e aprender com suas experiências, de discutir, trocar experiências, de observar opiniões diversas sobre um mesmo assunto. Em suas palavras, proporciona condições de ouvir e observar outros profissionais em atuação, é como um espelho, um exemplo a ser seguido para nos modificar ou melhorar. 


\section{Sobre as reuniões de compartilhamento}

P2 declara ter aprendido muito com as experiências dos outros profissionais, ressaltou o fato de ter contato com pontos de vista diferenciados para um mesmo problema ou situação, como importante contribuição para o seu desenvolvimento. Em sua opinião, o fato de ter oportunidades de trocar opiniões sobre casos complexos, de discutir com o grupo e coletar opiniões e visões de diferentes da nossa simplifica e facilita a execução das atividades, aumenta o valor dos trabalhos e gera economia de tempo. Além disso, temos a possibilidade de conhecer entender melhor o trabalho realizado pelas demais áreas.

\section{Acompanhamento dos orientadores em atividades práticas:}

P2 reconheceu a importância de contar com a experiência de seu orientador. Embora tenham ocorrido alguns desencontros de agenda, P2 declara que nas visitas de acompanhamento sempre obteve orientação e auxílio e declarou: recebi muitas contribuições para a minha formação profissional e para o desenvolvimento e consolidação da minha área de atuação.

Acompanhamento de outros profissionais, diferentes de seus orientadores, em atividades práticas (orientação cruzada):

Para P2, essa atividade foi de grande importância nas ações encadeadas do programa ADC. Na sua opinião, cada pessoa tem uma maneira, um estilo de trabalhar e se posicionar em diferentes situações e essa possibilidade de observação é riquissima.

\section{A3) A atividade de orientação ( $3^{a}$ esfera - disseminação)}

P1: Esse profissional demonstrou muito reconhecimento em relação às contribuições das orientações do profissional-modelo, responsável pelo seu desenvolvimento. Disse que a atividade de orientação possibilitou uma compreensão clara sobre seu desempenho e os caminhos para o desenvolvimento ou o aprimoramento das suas competências. Reconheceu que dessa forma pode agir com mais rapidez para se desenvolver. Declarou ainda, a possibilidade de ser orientador assusta um pouco, mas acho que será mais um incentivo para o meu desenvolvimento. 
P2: Para P2, a atividade de orientação é uma ótima estratégia de ensinamentos. Na sua opinião, é se o melhor caminho para a formação de um número cada vez maior de profissionais na empresa. Pretendo empreender esforços para ampliar a minha participação no acompanhamento e observação da atuação de meu orientador e de outros profissionais.

\section{A4) Incentivo à prática ( $4^{2}$ esfera)}

P1: O profissional declarou que o maior incentivo para essas práticas é saber que estamos sendo avaliados, que o nosso esforço para a realização dessas atividades será notado por alguém e, no futuro, será recompensado.

P2: Para P2, todo o trabalho e atividades práticas desenvolvidas foram imprescindiveis para maior segurança do profissional na realização do seu trabalho, para o seu desempenho e desenvolvimento.

\section{B. Avaliação geral do programa}

P1: P1 afirmou: sem dúvida nenhuma foi o melhor programa de treinamento que jả participei, pois foi possivel aliar atividades meramente teóricas com situações práticas, numa interação adequada. Não havia distanciamento entre as discussões e a vida prática, e, ainda, nos propiciava a oportunidade real de viver as situações descritas nas reuniōes. P1 ressalta a importância da integração das ações para o aprendizado e de desenvolvimento implementadas na ADC: Num momento recebiamos informações. Em outro, éramos estimulados a aprender $e$ apresentar a nossa visão sobre determinados fatos, discutir assuntos diversos com profissionais criticos, aprender a sustentar nossas opiniōes e nos confrontarmos com idéias diferentes no ambiente interno da empresa. Em outro momento, acompanhávamos na prática as dificuldades encontradas nas reuniōes, inicialmente apenas verificando como nossos orientadores se portavam e depois nós mesmos enfrentando essas situações. Pl declara: para mim, foi de grande importância o estimulo à perfeição, se um trabalho não for bem feito, a reação é imediata, mas, a "bronca" nunca vem desacompanhada da correção do trabalho $e$ da orientação para evolução do aprendizado. 
P2: Para P2 as contribuições são inúmeras no tocante ao desenvolvimento pessoal e profissional. A Academia é uma oportunidade de troca de vivência e experiência entre todos os envolvidos. Isto contribui diretamente para o desempenho das atividades de trabalhos. P2 vê no programa uma oportunidade para estreitar relacionamentos e conhecer como os outros participantes pensam e trabalham, quais as principais dificuldades que enfrentam e como fazem para solucioná-las: a $A D C$ é uma oportunidade direta de aprendizado, de troca de experiências e discussão de casos, de muito valor para as nossas atividades. Além disso, esses contatos, muitas vezes, funcionam como um espelho, onde podemos observar criticamente as ações dos outros e comparar com as nossas próprias ações. Todas as atividades agregam conhecimentos diretos elou indiretos para a formação pessoal $e$ profissional do participante.

Ambos se declararam cientes da importância do desenvolvimento das competências de orientação para clientes e mercado, de desenvolvimento de negócios e produtos, para a concretização dos objetivos organizacionais.

\subsubsection{Relatório da entrevista coletiva com os orientadores (profissionais-} modelo)

O roteiro da entrevista coletiva com os orientadores constou dos seguintes tópicos:

A. Contribuição das etapas do programa $\mathrm{ADC}$ no desempenho e desenvolvimento dos seus orientados:

A 1) provimento de informações ( $1^{\mathrm{a}}$ esfera);

A2) compartilhamento de conhecimentos e experiências - aprendizado em grupo (2a esfera);

A3) a atividade de orientação como disseminação - $3^{\mathrm{a}}$ esfera e A4) incentivo à prática ( $4^{\mathrm{a}}$ esfera).

B) Avaliação geral do programa 


\section{A) Contribuição das etapas do programa ADC no desempenho de seus orientados:}

\section{A1) provimento de informações ( $1^{\mathrm{a}}$ esfera);}

Os orientadores vêem essa etapa como o ponto de partida para o desenvolvimento das competências, uma preparação para a prática. Muitas vezes elas tinham uma ou outra informação sobre os temas que foram ministrados, ou intuíam, mas de forma desconexa, desordenada. Acreditam que as atividades contribuíram para a organização dos conceitos idéias dentro de um sistema, induzindo as pessoas a um pensamento mais abrangente ou sistêmico. Admitiram que os temas variados, diferentes da especificação técnica legal, forma o advogado para compreender melhor o funcionamento de uma empresa e lidar melhor com o cliente.

\section{A2) compartilhamento de conhecimentos e experiências - aprendizado em grupo ( $2^{\mathrm{a}}$ esfera);}

Reuniões de compartilhamento: Os orientadores vêem as reuniões como grandes possibilidades de aprender com as reflexões sobre os casos práticos. Reproduzindo suas palavras, aqui eles conseguem, através das discussões $e$ debates, reformular idéias e conceitos, reorientar comportamentos e reações, evitando que isso ocorra em uma situação real, concreta, o que poderia causar prejuizo. A diversidade de visões e opiniões ajuda muito. Depois das discussões sempre chegamos a um consenso. Os orientadores notam que os profissionais em desenvolvimento refletem, aceitam e reorganizam suas visões em relação aos assuntos debatidos.

Acompanhamento prático: os orientadores reconheceram o importante papel dessa atividade para o desenvolvimento dos seus orientados e descreveram como essa atividade ocorre: nas visitas de acompanhamento eles ficam mais da posição de observadores. No caminho de volta sempre conversamos sobre a experiência compartilhada, ressaltando pontos fortes e situações críticas, falhas e correções. Um dos orientadores declarou: tenho plena liberdade para assumir e comentar qualquer falha minha, se acontecer. Isso também é aprendizado. 
Acrescentaram que: muitas vezes, os orientados nos solicitam para acompanhálos na aplicação prática das suas competências, quando eles realizam as próprias visitas a clientes. $\dot{E}$ uma situação muito rica, pois podemos analisá-los enquanto atuam e a atividade de orientação aqui é ainda mais efetiva.

\section{A3) a atividade de orientação como disseminação}

Os orientadores declararam não ver forma mais eficaz para a disseminação das suas competências e desenvolvimento da equipe, considerando o serviço que a empresa oferece. Essa ferramenta está dando muito resultado.

\section{A4) Incentivo à Prática}

Os orientadores acreditam que a sobreposição das fases é um fator relevante no sucesso do aprendizado. Reconhecem que dessa forma, o conceito fica bem próximo da prática, não dá tempo para esquecer. Isso é visível nas visitas de acompanhamento. $O$ que se aprende nos treinamentos da primeira etapa (1" esfera), é discutido e compartilhado em temos de experiências vivenciadas nas reuniōes quinzenais e experimentado no contexto real durante as visitas de acompanhamento ( $2^{\mathrm{a}}$ esfera) e aplicado na prática ( $4^{\mathrm{a}}$ esfera). A seqüência ou $O$ encadeamento de ações dá maior efetividade ao aprendizado dos orientados.

\section{B. Avaliação geral do programa}

Para os orientadores, o programa trouxe grandes contribuições e relatam seus próprios sentimentos: a atividade de orientação é uma responsabilidade muito grande que nos força a uma maior preparação, pois servimos de modelo. Os orientados estão sempre nos observando, avaliando, imitando e formando seus próprios julgamentos.

Reconhecem que, além de desenvolver os orientados, os orientadores e os convidados também se desenvolvem: estamos sempre falando do ponto de vista do aprendizado de quem está sendo desenvolvido. Mas o programa também contribui para o nosso desenvolvimento. A participação de outros profissionais experientes, os convidados, enriquece as discussões e o intercâmbio. Termos contato com o conhecimento e experiência das outras pessoas. Isso nos ajuda a desenvolver novas soluções e enxergar novos caminhos. 
Isso nos faz pensar que há outras formas de se ver as coisas, nos induz à auto-critica. Assim nos desenvolvemos também.

De forma geral, os orientadores avaliam o programa como ótimo e declaram: gostariamos de ter tido a oportunidade de participar de algo parecido no início da nossa carreira.

\subsubsection{Depoimentos dos demais participantes}

Foram convidados a expor suas percepções em relação ao programa ADC os profissionais que participaram mais vezes das atividades desenvolvidas no programa. Durante a reunião de fechamento do ano de 2004 , escreveram de próprio punho as suas percepç̃es. A seguir, os depoimentos coletados são reproduzidos em suas próprias palavras:

- Participante 1: O programa foi muito bem organizado e planejado, de forma a integrar as informações transmitidas nos treinamentos com os temas discutidos nas reuniões de compartilhamento e com os próprios resultados cobrados dos profissionais. No meu caso, com bastante certeza, afirmo que a desenvoltura e as habilidades de relacionamento com os clientes foram muito desenvolvidas.

- Participante 2: O programa como um todo foi de fundamental importancia. Para mim, particularmente, contribuiu para que eu pudesse desenvolver mais minhas competências, aprimorar e desenvolver técnicas, principalmente no que se refere a atendimento a clientes.

- Participante 3: Participar do programa oferece condições de ampliar os conhecimentos sobre as estruturas, os produtos e sobre o que a empresa espera de seus profissionais. Tenho procurado aplicar no meu dia-a-dia todos os conteúdos trabalhados no programa. 
- Participante 4: O programa é de suma importância para o desenvolvimento da equipe, por abordar conceitos e práticas que, na maioria das vezes, é muito dificil aprender sozinho. Nota-se que foi preparado de maneira integrada e consistente, resultando em alto indice de aproveitamento.

- Participante 5: O programa oferece aos participantes aprendam conceitos e desenvolvam competências que geralmente não fazem parte da preocupação de outras empresas de advocacia. A empresa prepara o advogado para atuar em um mercado em que apenas o conhecimento técnico não é mais suficiente.

\subsection{Notas da Observação Direta e Participante:}

Os profissionais em desenvolvimento demonstraram estar altamente comprometidos. Seu indice de freqüência nas reuniões quinzenais foi considerado muito bom no período (acima de $80 \%$ ). Suas ausências eram devidas a compromissos internos ou externos envolvendo clientes. Isso significa que estavam desenvolvendo atividades da quarta esfera (aplicação do conhecimento na prática - Figura 15, p. 85). Uma das duplas, orientadororientado, foi homenageada por ter participação de $100 \%$ nas reuniōes. Em todas as reuniões, eram muito participativos e questionadores, demonstrando energia e vontade de aprender.

Puderam ser observados comportamentos que indicaram alto nível de comprometimento dos profissionais-modelo com o projeto, como: disponibilidade para participar das discussões sobre a definição dos casos práticos a serem apresentados, para preparar seus relatos e compartilhar suas experiências e conhecimentos com o grupo com riqueza de detalhes, para dar orientações e suporte aos orientados.

As reuniões nunca aconteceram sem que pelo menos um dos profissionais-modelo estivesse presente.

Foi perceptivel o estreitamento do relacionamento entre os participantes do programa no decorrer do período. Isso se verifica também, embora com menor intensidade, com relação aos profissionais convidados, que ao trazerem suas contribuições, também se beneficiam do programa para o próprio desenvolvimento. 
Segundo comentários dos profissionais em desenvolvimento, compartilhar o mesmo espaço fisico com seus orientadores no dia-a-dia de suas atividades poderia ter acelerado o processo de desenvolvimento das suas competências melhorando os resultados dos indicadores. Atualmente orientadores e orientados são alocados em salas diferentes.

As pessoas aparentam sentir-se privilegiadas ao fazerem parte desse projeto. Profissionais que ainda não participam do programa frequentemente manifestam o desejo de participar.

Dentro do grupo, as pessoas demonstram liberdade e coragem para expor suas idéias e opiniões, pedir auxílio etc. Isso não acontece com naturalidade fora do ambiente da ADC. Esse fato é corroborado pelos conteúdos das entrevistas e depoimentos.

Muitas vezes, durante as reuniões, as discussões se acaloravam sendo necessária a intervenção da coordenação do programa para direcionar o consenso, ou a convergência. Isso, no entanto, não causou nenhum prejuízo ao clima ou ao relacionamento entre os integrantes do grupo.

Nas reuniões, além de discutirem conhecimentos e experiências vivenciadas, o grupo trabalhou na criação de um produto interno: um manual que deveria refletir o padrão de atendimento a clientes. A participação foi maciça. Profissionais-modelo, profissionais em desenvolvimento e convidados se envolveram com afinco nessa criação. No momento do encerramento da coleta de dados para este estudo, o manual estava em fase de revisão para posterior edição.

Foram verificadas ações gerenciais que se somavam ao programa como indicações de profissionais para atividades didáticas, concessão de palestras e treinamentos através de contatos da alta gestão da empresa. Muitos profissionais desenvolveram essas atividades por intermédio dos sócios. Exemplo disso é que um dos profissionais em desenvolvimento foi indicado para coordenar um curso de pós-graduação em universidade local, outro foi indicado para ministrar aulas nesse mesmo curso.

Outra ação gerencial foi a criação de um comitê, do qual fazem parte os integrantes da $\mathrm{ADC}$, que se reúne periodicamente para produção de materiais para a imprensa, assessorado por profissional especializado nessa área. Essas ações gerenciais auxiliaram muito no desenvolvimento das competências de auto-exposição para comunicação da imagem institucional e, conseqüentemente da marca. Isso também vai refletir positivamente no desenvolvimento de novos negócios 
A divulgação periódica de indicadores, como os apresentados neste trabalho, é outra ação gerencial que permite que os profissionais acompanhem seus resultados e tenham condições de se auto-avaliar e reorientar suas ações de desenvolvimento em caso de necessidade. 
CAPÍTULO 5

ANÁlISE DOS DADOS COLETADOS 
A análise dos dados coletados será apresentada na seqüência abaixo, obedecendo a mesma ordem da apresentação dos objetivos específicos apresentados na introdução do trabalho (p. 4).

- Análise do contexto em que a pesquisa se desenvolve;

- Análise do processo de elaboração do padrão referencial de competências organizacionais e individuais, que embasa o sistema de gestão por competências;

- Análise do processo de identificação das deficiências das competências, cujo desenvolvimento é o foco do programa estudado;

- Análise do sistema de gestão do conhecimento aplicado para o desenvolvimento de competências no programa Academia de Desenvolvimento de Competências (ADC), com base no modelo conceitual elaborado;

- Análise dos indicadores de desempenho do programa e

- Análise do desempenho do programa comparando os periodos janeiro a outubro de 2003 (T0) e janeiro a outubro de 2004 (T1).

\subsection{Análise do contexto em que a pesquisa se desenvolve}

O segmento de consultoria e assessoria jurídica apresenta um número reduzido de empresas em condições de competir estrategicamente no mercado brasileiro. Considerando o estágio em que a grande maioria se encontra em termos de visão estratégica e práticas de gestão, torna-se mais difícil a superação dos desafios impostos pelos efeitos da globalização no mercado, no perfil dos clientes, no perfil da concorrência, nos tipos de demandas etc. É possivel que bem poucas consigam sobreviver nesse ambiente inseguro, marcado por mudanças rápidas e freqüentes, pela exigência de decisões e respostas rápidas e eficazes.

O despreparo da maior parte da concorrência e o aumento da demanda por serviços jurídicos são fatores que podem ser considerados como uma oportunidade a ser explorada. Isso pode ser considerado fonte de vantagem competitiva de origem externa, com base na estrutura do setor, concorrência e mercado (VASCONCELOS; CYRINO, 2000).

Considerando o estágio dos concorrentes, um bom sistema de gestão de negócios, um sistema de gestão de pessoas alinhado aos objetivos de negócios e um plano estratégico bem 
estruturado e a criação de uma cultura de aprendizado e conhecimento podem ser considerados fontes de vantagem competitiva de origem interna, com base na cultura, conhecimentos, competências organizacionais (VASCONCELOS; CYRINO, 2000).

Se no ambiente empresarial, de forma geral, desenvolver competências ou desenvolver conhecimento organizacional são recursos de diferenciação em relação à concorrência, conforme argumentam Prahalad; Hamel (1990), Drucker (1994, 2001) e Von Krogh; Ichijo; Nonaka (2001), no cenário que se apresenta para o segmento jurídico esses recursos têm seu peso potencializado.

A ameaça da entrada de empresas estrangeiras no mercado brasileiro pode estar amenizada pela burocracia e pela carência de adequações dos poderes judiciário e legislativo à nova realidade mundial, pois são fatores que dificultam sua adaptação à cultura brasileira.

No entanto, verifica-se uma onda de fusões ocorridas principalmente após o ano 2000, entre empresas nacionais e empresas estrangeiras. Esse movimento, de um lado fortaleceu as empresas nacionais, ampliando seus mercados para territórios internacionais, de outro, facilitaram a entrada das empresas estrangeiras no país, aumentando a concorrência interna. Mesmo assim, o cenário ainda se mostra favorável para as empresas que conseguirem se conscientizar da complexidade do ambiente em que atuam, desenvolver rapidamente uma visão estratégica, implementar sistemas de gestão, elaborar e implantar planos estratégicos alinhados com essa visão.

Com relação à empresa estudada, o seu indice de crescimento pode indicar capacidade diferenciada em gestão de negócios, visto que em 15 anos de existência foi alçada a uma posição entre as 10 maiores empresas nacionais do segmento jurídico.

A empresa apresenta indícios de disposição e interesse em implementar modernas técnicas de gestão, o que pode colocá-la em posição de vantagem em relação à concorrência. São evidências disso a sua estrutura tendendo à horizontalização, a preocupação com a elaboração de estratégias, a existência de objetivos definidos, a implementação de sistema de gestão por competências com o cuidado de alinhá-lo aos objetivos organizacionais, os planos de fusão e aquisição de outras empresas para ampliar sua área de atuação, a intenção de desenvolver cultura orientada para clientes e mercado refletida no seu padrão referencial de competências e a implementação do sistema de gestão do conhecimento, objeto deste estudo. 


\subsection{Análise do processo de elaboração do padrão referencial de competências}

O processo de elaboração do padrão referencial de competências envolveu, além da alta gestão, um comitê composto por lideranças representativas da empresa e por profissionais de nivel técnico. Houve a preocupação em criar uma visão compartilhada por todos os colaboradores em torno da complexidade do ambiente externo e da necessidade de se preparar internamente. A empresa procurou dar condições para que as pessoas entendessem que 0 desenvolvimento daquelas competências possibilitaria 0 alcance dos objetivos organizacionais. O envolvimento dessas pessoas conferiu legitimidade ao processo de construção do padrão referencial.

O patrocínio da alta gestão, bem como o envolvimento das lideranças representativas na elaboração do padrão referencial, favoreceram a criação de significado e visão compartilhada sobre o conhecimento a ser desenvolvido. Propiciaram melhores condições de compreensão da importância desses conhecimentos para a formação das competências necessárias ao crescimento da empresa.

A vinculação de todos os sub-sistemas de gestão de recursos humanos (recrutamento e seleção, treinamento e desenvolvimento, remuneração e gestão do desempenho) ao padrão referencial de competências deu mais consistência ao processo de conscientização das pessoas quanto à necessidade de mudança.

\subsection{Análise do processo de identificação das deficiências das competências foco do programa em estudo}

A diversidade de avaliadores envolvidos no processo de identificação das competências individuais e deficiências existentes minimizou significativamente o grau de subjetividade das avaliações. A auto-avaliação foi um importante instrumento de preparação dos profissionais para a entrevista de feedback. A auto-análise serviu para induzi-los a uma reflexão sobre as próprias potencialidades e necessidades de desenvolvimento, diminuindo a tendência natural de rejeitar possíveis críticas e aumentando a probabilidade de aceitação de orientações de desenvolvimento. 
O resultado do mapeamento das competências para diagnosticar a situação real deu consistência ao processo de priorização dos conhecimentos a serem desenvolvidos para criar a base de conhecimento para a formação das competências organizacionais.

Verifica-se uma redundância de informações para a criação da visão compartilhada da necessidade de se criar ou desenvolver os conhecimentos envolvidos no padrão referencial de competências. Algumas pessoas foram envolvidas na elaboração do padrão referencial de competências. Nos workshops as pessoas conheceram o padrão e trabalharam para compreender a relação entre os conhecimentos a serem desenvolvidos e as estratégias organizacionais. Novamente tiveram que utilizá-lo para realizar a auto-avaliação. O padrão também serviu de referência para os avaliadores na preparação da avaliação e posteriormente para a entrevista de feedback.

O padrão referencial reflete o profissional ideal para os negócios. Conhecê-lo, compreendê-lo e interiorizá-lo direciona o profissional no desenvolvimento das suas competências e da sua própria carreira. A consciência do profissional com relação às suas deficiências e a sua disponibilidade de investir no seu desenvolvimento o torna mais aberto às açōes da gestão do conhecimento.

\subsection{Análise da aplicação prática do modelo conceitual de sistema de gestão do conhecimento para o desenvolvimento de competências.}

Recapitulando, o modelo conceitual de gestão do conhecimento aplicado no programa ADC é composto por quatro esferas em torno de um núcleo. O núcleo representa a criação de significado, a visão compartilhada da necessidade do conhecimento a ser criado. A primeira esfera envolve ações de criação do conhecimento individual. A segunda esfera trata das conversões do conhecimento individual para a aprendizagem em grupo. A terceira esfera envolve ações de disseminação desse conhecimento para todos os níveis organizacionais. A quarta esfera trata da utilização do conhecimento criado.

$\mathrm{Na}$ prática, as ações concentradas no núcleo (promoção do compartilhamento da visão do futuro, ou a criação de significado para a necessidade de se desenvolver as competências para alcançar os objetivos) se viabilizaram principalmente por meio dos workshops. É necessário esclarecer que apenas os profissionais selecionados por apresentarem 
maior potencial de desenvolvimento participam das atividades da ADC. No entanto, todos os colaboradores foram convidados a participar dos workshops.

Adicionalmente, o compartilhamento dessa visão recebeu importantes contribuições dos processos de elaboração do padrão referencial e de diagnóstico das deficiências das competências no plano real. Tais contribuições foram devidas à necessidade da utilização do padrào referencial por repetidas vezes no decorrer desses processos.

Alguns modos de conversão do conhecimento podem ser notados no processo de criação do significado dos conhecimentos a serem desenvolvidos. Ao divulgar o padrão referencial de competências os instrutores praticaram a externalização, quando apresentaram e explicaram o sistema através do filtro do seu modelo mental. Trabalham para promover a compreensão e internalização por parte dos colaboradores, A combinação ocorreu pela utilização de materiais impressos e áudio-visuais na exposição dos conceitos. A compreensão da visão do futuro e do significado dos conhecimentos a serem desenvolvidos, por parte dos colaboradores, reflete a internalização.

As dinâmicas de grupo aplicadas para que as pessoas trabalhassem com os novos conceitos e compreendessem a necessidade de mudança e desenvolvimento, proporcionou condições de aprendizagem em grupo, facilitando o processo de compartilhamento e criação de objetivos comuns (SENGE, 1990) ou a visão instilada do conhecimento de Von Krogh; Ichijo; Nonaka (2001).

O trabalho de conexão do padrão referencial de competências com os objetivos organizacionais e com as estratégias definidas para atingi-los, proporcionou condições para a criação da visão sistêmica, para a compreensão da importância de cada uma das partes do todo para o alcance dos objetivos comuns.

$O$ fato de se realizar um trabalho de maior profundidade com os lideres evidencia a importância dada pela empresa ao papel da liderança na formação da cultura e da implementação das estratégias organizacionais.

O envolvimento de todos os colaboradores na criação da visão compartilhada dos conhecimentos necessários para a empresa alcançar seus objetivos, contribuiu para ampliar as condições para um clima propício ao aprendizado e ao desenvolvimento pessoal e organizacional. Esse fato ratificou os argumentos de Zarifian (2001). Para o autor, o entendimento compartilhado sobre os objetivos organizacionais propicia o desenvolvimento conjunto das ações necessárias para a sua concretização. 
As ações de criação de significado ou compartilhamento da visão do futuro, contidas no núcleo, também encontram sustentação nas teorias de Senge (1990), Nonaka; Takeuchi (1997), Perez-Bustamente (1999) e Von Krogh; Ichijo; Nonaka (2001).

As ações de promoção da visão compartilhada do futuro desejado e do conhecimento necessário para concretizá-lo, não se concentraram apenas nesses workshops, que foram o ponto de partida do programa. Elas continuam nos programas de integração de cada novo colaborador admitido pela empresa. Do mesmo modo, a continuidade se verifica em todas as demais esferas do sistema, que tiveram um ponto de início no tempo, mas não têm um ponto de término.

$\mathrm{Na}$ primeira esfera, a criação de conceitos, uma das fases da criação do conhecimento de Nonaka; Takeuchi (1997), ocorre por meio de aulas expositivas. No módulo introdutório, profissionais com maior experiência e maturidade profissional, portadores das competências do padrão referencial, atuam como instrutores compartilhando seus modelos mentais e externalizando seus conhecimentos tácitos, que se cristalizam na forma de conhecimento explícito. O mesmo ocorre nas aulas ministradas pela consultoria especializada no módulo avançado. As ações concentradas na primeira esfera se assemelham ao que Leonard-Barton; Swap (1999) consideram a primeira fase da criação: a preparação, considerando que a criatividade só brota quando o "solo mental" estiver muito bem preparado.

Os instrutores procuram induzir os processos internos ao individuo (interpretação, reflexão e conexão das informações) por meio de atividades vivenciais como dinâmicas de grupo, simulações, debates e discussões sobre os temas abordados. Os participantes demonstram alto grau de envolvimento com essas atividades.

Os conhecimentos externalizados pelos instrutores passam pelo filtro do modelo mental dos aprendizes, passando a compor sua base de conhecimento tácito, pela internalização, resultando na criação do conhecimento individual.

Não se pode deixar de ressaltar que o acesso direto à internet, a intranet, a biblioteca local, bem como os clippings disponibilizados diariamente com o resumo das notícias relacionadas ao negócio, publicadas nos principais jomais do país, são importantes fontes adicionais de informações, as quais os profissionais são constantemente estimulados a consultar. 
O conteúdo das entrevistas mostrou que os profissionais em desenvolvimento reconheceram a importância do provimento de informações para a formação do conhecimento individual. Pela análise dos depoimentos, as informações teóricas para a criação de conceitos de orientação para mercado, orientação para clientes e de gestão organizacional em geral, estão desenvolvendo nos participantes a capacidade de sistematização, de elaboração de métodos e técnicas que podem facilitar e aumentar a qualidade do seu trabalho.

Na segunda esfera do modelo também se verificam os modos de conversão do conhecimento, porém com maior ênfase na socialização, quando orientadores e orientados compartilham experiências passadas e práticas presentes.

A externalização ou a conversão do conhecimento tácito em explícito ocorre nas reuniões de compartilhamento, quando as experiências e conhecimentos são expostos e debatidos. Os debates provocam a reflexão dos membros do grupo e os conhecimentos explicitados pelos orientadores são internalizados pelos profissionais em desenvolvimento, passando também a compor sua base de conhecimentos.

A observação dos orientadores em plena atividade profissional, bem como o relato sobre o aprendizado resultante dessa observação, possibilitam a conversão do conhecimento tácito dos orientadores para o conhecimento tácito dos profissionais em desenvolvimento.

Nesta esfera, pode-se identificar o que sugerem Von Krogh; Ichijo; Nonaka (2001) com seus conceitos de gerenciamento de conversas e Senge (1995) com o aprendizado em grupo através de diálogos e raciocínio coletivo. Também acontece a abrasão criativa de Leonard-Barton; Swap (1999), quando as discussões e debates se aquecem com opiniões que divergem para convergir no final, quando os participantes chegam a um consenso coordenado pelos orientadores.

A conexão analógica de Sarvary (1999) também se faz presente nesta esfera. Vários problemas e soluções encontradas pelos participantes da ADC no exercício de suas atividades são discutidos possibilitando sua adaptação e aplicação em outras situações, envolvendo outros clientes.

$\mathrm{Na}$ terceira esfera as atividades de disseminação do conhecimento são desenvolvidas pelos profissionais-modelo em suas atividades de orientação para a formação dos profissionais em desenvolvimento. Em futuro próximo, esses profissionais virão a se tormar também orientadores, de forma a multiplicar o número de disseminadores do conhecimento. Resgatando a teoria abordada no levantamento literário, em seus estudos sobre 
a gestão do conhecimento em empresas de consultoria, Dunford (2000) já afirmava que cada consultor deveria facilitar e promover o aprendizado e o desenvolvimento dos profissionais menos experientes.

A disseminação do conhecimento é a ação que foca a transformação do conhecimento do grupo em conhecimento organizacional.

Embora não tão focadas como as atividades de orientação, outras atividades de disseminação podem ser verificadas em outras esferas como a atuação dos participantes como instrutores internos, resultante dos estímulos à aplicação prática do conhecimento criado ( $4^{\mathrm{a}}$ esfera).

A disseminação do conhecimento também pode ser verificada na atividade de profissionais mais experientes ministrando disciplinas na fase de provimento de informações ( $1^{\mathrm{a}}$ esfera).

Tomando por base as estratégias de gestão do conhecimento propostas por Hansen; Nohria; Tierney (1999), a estratégia definida pela empresa para a disseminação do conhecimento se assemelha ao que os autores denominam person-to-person, que envolve o desenvolvimento de redes de relacionamentos para conectar as pessoas para que o conhecimento, principalmente o tácito, possa ser compartilhado.

As ações de estímulo à aplicação prática do conhecimento concentradas na quarta esfera se concretizam pela monitoração e mensuração das atividades realizadas pelos profissionais em desenvolvimento. Em outras palavras, toda atividade realizada por esses profissionais que demande a aplicação das competências foco do programa são registradas para compor indicadores, os mesmos apresentados no item 4.4. (p. 105).

A apresentação periódica e discussão dos resultados desses indicadores com os profissionais em desenvolvimento e seus orientadores, servem como estímulo e orientação na prática das competências em desenvolvimento.

Também se pode reconhecer a espiral do conhecimento de Nonaka; Takeuchi (1997) na aplicação prática do modelo, na qual a criação do conhecimento começa no indivíduo e, pela interação dos quatro modos de conversão do conhecimento pode ser disseminado para todos os níveis da organização.

As cinco fases do processo de criação do conhecimento organizacional, propostas por Nonaka; Takeuchi (1997) - o compartilhamento do conhecimento tácito, a criação de 
conceitos, a justificação desses conceitos, a construção de um arquétipo e a difusão interativa do conhecimento - foram verificadas no programa ADC:

- a criação de conceitos ocorrendo na primeira esfera do sistema, na qual o modelo mental e o conhecimento tácito dos instrutores são expressos em palavras, números, códigos e conseqüentemente cristalizados na forma de conhecimento explícito, através da externalização. Nessa fase os profissionais em desenvolvimento tiveram os primeiros contatos mais profundos com os conceitos de marketing, mercados, clientes, concorrentes etc.

- o compartilhamento do conhecimento tácito se verifica nas atividades práticas desenvolvidas na segunda esfera. Nessas atividades, os profissionais em desenvolvimento acompanham seus orientadores e outros profissionais mais experientes, observando a atuação deles em situações de aplicação das suas competências.

- a justificação dos conceitos pode ser percebida nas atividades desenvolvidas nas reuniões de compartilhamento, onde se reconhece a importância da aplicação prática dos conceitos criados, para que a organização tenha condições de implementar suas estratégias para o alcance dos seus objetivos de negócios.

- o grupo tem trocado conhecimentos e experiências sobre relacionamentos com clientes, qualidade de serviços, agilidade na apresentação de soluções criativas e excelência de atendimento. A partir dessas discussões o grupo está elaborando o esboço de um manual que traduza o padrão de excelência de serviços a clientes. Essa atividade pode ser reconhecida como a construção de um arquétipo, em que o conceito justificado é transformado em algo concreto, tangivel. Quando o manual do padrão de excelência em serviços estiver concluído, os integrantes da ADC pretendem disseminar seus conceitos, através de treinamentos e workshops, para os demais profissionais da organização. Aqui se reconhece a quinta e última fase: a difusão interativa do conhecimento.

- a difusão interativa do conhecimento verifica-se principalmente nas atividades dos profissionais-modelo, no seu papel de orientadores. Papel esse, que será assumido pelos profissionais em desenvolvimento assim que estiverem preparados para tal. 


\section{Condições e fatores favoráveis aos processos de GC.}

Ainda com relação à aplicação prática do modelo conceitual de sistema de GC para o desenvolvimento de competências, evidências resultantes da observação direta e participante revelaram alguns aspectos relacionados às condições favoráveis sugeridas pelos diversos autores pesquisados, sintetizadas no Quadro 4 (p. 35).

\section{Ambientes e relações:}

O ambiente de solicitude (confiança, empatia, leniência ao julgar, acesso à ajuda e coragem) pode ser percebido entre os integrantes do programa, que aparentam nutrir sentimentos de confiança mútua. Os profissionais em desenvolvimento apresentam comportamentos que denotam liberdade e coragem para expor suas idéias, opiniões, dúvidas e fraquezas, bem como não se intimidam em solicitar ajuda e orientações a seus orientadores. Em seus depoimentos sobre as atividades práticas, relatam que confiam nas competências de seus orientadores e, sempre que necessário, solicitam auxílio e até requerem a presença deles em suas visitas e reuniões com clientes para lhes dar suporte. A existência desse ambiente entre os integrantes da ADC fica também evidenciada pelos dados coletados nas entrevistas.

Conversas informais e conteúdos de correspondências internas sugerem a existência do pressuposto de que a categoria profissional (advogados) é resistente em demonstrar deficiências e desconhecimentos. Isso torna dificil o ato de solicitar ajuda de terceiros. Segundo comentários observados durante as reuniões, esse sentimento foi consideravelmente minimizado no ambiente da ADC. Os dados coletados nas entrevistas dão sustentação a essas observações.

\section{Estrutura}

A estrutura organizacional tende para a horizontalização, apresentando poucos níveis hierárquicos. Verifica-se uma preocupação da alta gestão em evitar relações de subordinação entre gestores e equipes. Para fortalecer a idéia de interação e interdependência, e enfraquecer as relações hierárquicas rígidas, a empresa não adota as tradicionais nomenclaturas de cargos hierárquicos (diretoria, gerência, supervisão etc.) para as áreas de serviços a clientes. Porém, esse fator não foi analisado, pois no contexto do programa ADC, os niveis se reduzem a apenas dois: orientadores e orientados. 
Embora a empresa não possua ainda uma infra-estrutura de comunicação que suporte e facilite o fluxo de informações conhecimentos e idéias, verifica-se um esforço para criar recursos que facilite esse fluxo entre os integrantes da Academia. Outros esforços de caráter corporativo podem ser verificados através de ações como, por exemplo, a criação e estruturação da intranet, o acesso direto à internet, o acervo das bibliotecas, a disponibilização de clippings etc. Essa infra-estrutura que favorece o fluxo de comunicação não tem como foco principal as atividades de gestão do conhecimento ou desenvolvimento de competências, mas pode ser considerada um recurso que passou a ser utilizado também para essa finalidade.

\section{Estratégias e Ações Gerenciais}

No período da pesquisa, a empresa demonstrou a prática da disseminação de informações estratégicas divulgando e compartilhando com todos os seus colaboradores a sua missão, sua visão de futuro, seus objetivos e estratégias, bem como o conhecimento necessário para a implementação das estratégias e alcance dos objetivos organizacionais. A divulgação ocorreu durante os workshops realizados em dezembro de 2002 e maio de 2003.

Após a divulgação foi lançada uma campanha para consolidar as idéias e conceitos inerentes. Nessa campanha, o primeiro assunto abordado em reuniões durante todo o ano deveria ser o relato de ações relacionadas com a missão, voltadas para a concretização da visão de futuro, implementação das estratégias e para o alcance dos objetivos organizacionais.

$\mathrm{Na}$ apresentação de lançamento do programa Academia de Desenvolvimento, a empresa buscou estabelecer as relações existentes entre essa iniciativa e as idéias contidas na missão, visão, estratégias e objetivos organizacionais.

Verifica-se a concessão de autonomia aos profissionais, no que se refere a relações com clientes e na construção das soluções personalizadas oferecidas. $\mathrm{O}$ estímulo ao risco e tolerância a erros.

Quanto ao estimulo ao risco e tolerância a erros, a empresa estimula os profissionais em desenvolvimento para que realizem suas próprias visitas a clientes e não clientes, para que façam apresentações sobre a empresa, para que ministrem palestras sobre assuntos de sua área de atuação, para que concedam entrevistas, produzam artigos e atuem como instrutores internos. Os profissionais são expostos a riscos calculados e a empresa tem consciência de que 
erros poderão ocorrer, mas também acredita que isso faça parte do aprendizado desses profissionais.

Quanto ao nível adequado na concessão de autonomia, os profissionais gozam de autonomia relativa, principalmente nas relações com clientes e na construção das soluções personalizadas oferecidas.

Quanto à promoção da livre fluência de idéias em todos os níveis da organização, há o cuidado com o fluxo de informações e idéias entre os membros da ADC. No entanto, verifica-se ainda uma carência de ações e sistemas que facilitem e promovam esse fluxo nos demais niveis organizacionais. A empresa tem consciência do fato e planeja no futuro ampliar os canais de comunicação para melhorar o fluxo de informações e idéias e facilitar a disseminação do conhecimento organizacional.

O programa ADC realiza atividades de aprendizado em grupo, principalmente na segunda etapa, composta por sessões de compartilhamento e atividades práticas. As reuniões de compartilhamento são fruto de ação de gerenciamento de conversas e promovem espaço para a combinação de modelos mentais. É uma iniciativa que tem por objetivo criar ambientes e situações que propiciem o compartilhamento de idéias, conhecimentos e experiências, bem como a criação de novos conhecimentos. As induções a reflexões sobre a empresa, sobre as áreas que a compõem, seus clientes, concorrentes e mercados visam estimular o raciocínio sistêmico do grupo. Essas ações são reconhecidas e valorizadas pelos participantes da ADC, o que também se confirma pelos resultados das entrevistas.

Como o grupo ainda é pequeno, o papel de ativistas do conhecimento, nos processos de criação do conhecimento organizacional é exercido por profissional da área de treinamento. Lembrando que, segundoVon Krogh; Ichijo; Nonaka (2001), os ativistas são as pessoas responsáveis pela energização e integração dos esforços de criação de conhecimento na empresa. A intenção é identificar no grupo as pessoas com as características necessárias para representar esse papel no processo de multiplicação almejado pelo programa.

A valorização da diversidade e da heterogeneidade cognitiva pode ser notada na composição do grupo. Os integrantes pertencem a áreas diferentes: os três orientadores pertencem às áreas de recuperação de crédito, indenizações e contratual/societária. Os profissionais em desenvolvimento pertencem a áreas diferenciadas: penal empresarial, recuperação de crédito e ambiental. O grupo conta ainda com a participação de convidados contribuintes provenientes de áreas diversas como trabalhista, tributária, gestão de patrimônio, 
aduaneira etc. Alguns convidados, além da formação em direito possuem graduação ou pósgraduação em administração. Também as idades e tempo de experiência são bastante heterogêneos. Há profissionais de 25 anos de idade e nivel intermediário experiência até profissionais de mais de 60 anos de idade com vasta experiência profissional.

Essa diversidade facilita o processo de abrasão criativa, o surgimento de múltiplas idéias e opiniões, que o grupo procura respeitar e valorização e aproveitar.

Quanto a políticas e sistemas de gestão, as áreas de Recrutamento \& Seleção, Treinamento \& Desenvolvimento, Gestão do Desempenho e Remuneração foram remodeladas em função da implantação do modelo de gestão por competências.

As politicas de R\&S foram adequadas para selecionar profissionais alinhados com o modelo de competências, que requer uma cultura propicia ao conhecimento.

$\mathrm{Na}$ área de T\&D programas foram extintos, outros revisados e outros criados com foco no desenvolvimento das competências organizacionais e na formação de cultura de criação e compartilhamento do conhecimento. O programa $\mathrm{ADC}$ é um dos frutos desse movimento.

O sistema de Gestão do Desempenho sofreu mudanças radicais no que se refere a conteúdo, forma e significado. Passou a focar as competências organizacionais e individuais, às quais foram atribuídos pesos, de acordo com o grau de importância para as estratégias e objetivos da empresa. O caráter de orientação para o desenvolvimento se sobrepôs ao caráter de enquadramento de remuneração.

O sistema de remuneração também foi remodelado, porém ainda apresenta aspectos passiveis de ajustes, principalmente no que se refere à remuneração variável. No entanto, aparentemente, isso não gerou nenhum impacto significativo no desenvolvimento dos integrantes da $\mathrm{ADC}$, conforme mostram os indicadores e os depoimentos dos entrevistados.

\subsection{Análise dos indicadores de desempenho do programa ADC}

\section{Resultados de avaliações de desempenho e desenvolvimento:}

Esse indicador é genérico, pois traz uma avaliação do desempenho e do desenvolvimento do profissional, em relação a todas as competências componentes do padrão 
referencial, não só em relação às competências foco do programa ADC. Porém, essas competências foram facilmente isoladas do conjunto, visto que o sistema de gestão do desempenho trata esses grupos de forma separada.

\section{Quantidade de visitas a clientes atuais e em prospecção}

Este indicador demonstra o esforço do profissional em exercitar suas competências de identificação de oportunidades de criação de produtos, de conversão de oportunidades em negócios (percepção, criatividade e realização) e, indiretamente, sua competência em comunicar a imagem institucional (auto-exposição e oratória).

\section{Quantidade de propostas emitidas}

Evidencia a competência do profissional em perceber oportunidades para a criação de produtos e geração de novos negócios (percepção e criatividade).

\section{Quantidade de propostas aceitas}

Esse indicador revela a competência do profissional para a conversão de oportunidades e novos negócios (concretização).

Quantidade de inserções na mídia e quantidade de palestras e apresentações

O principal objetivo desses indicadores é evidenciar a competência de comunicação da imagem institucional (auto-exposição e oratória). Indiretamente, revelam o conhecimento sobre a empresa seus produtos, pelos temas apresentados pelos profissionais.

\section{Resultado da pesquisa de satisfação de clientes}

Esse indicador tem como principal objetivo avaliar as competências de qualidade em serviços e relacionamento com os clientes.

\section{Evolução de faturamento}

Aumentar a receita deve ser a conseqüência natural do desenvolvimento e aplicação dos conhecimentos desenvolvidos no programa, daí a importância desse indicador.

Os indicadores apresentados visam à complementação da parte qualitativa da pesquisa. 
5.5.1. Análise dos indicadores de desempenho dos profissionais em desenvolvimento (P1, P2 e P3)

\section{Visitas a clientes atuais e em prospeccão:}

P1) Os resultados indicaram que em 10 meses, janeiro a outubro de 2004, P1, aumentou em 2,2 vezes, ou em $118 \%$ o número de visitas a clientes e clientes em prospecção, em relação ao mesmo periodo em 2003.

P2) Os resultados indicaram que em 10 meses, janeiro a outubro de 2004, P2 aumentou em 2,5 vezes, ou em $154 \%$ o número de visitas a clientes e clientes em prospecção, em relação ao mesmo periodo em 2003.

P3) Em 10 meses, de janeiro a outubro de 2004, os resultados indicaram que P3 aumentou em 4 vezes o número de visitas a clientes e clientes em prospecção. Em termos percentuais, o seu desempenho foi 300\% superior, em relação ao mesmo período em 2003.

\section{Apresentação de propostas:}

P1) De janeiro a outubro de 2004, P1 emitiu 2,3 vezes mais propostas, $129 \%$ a mais em relação ao mesmo período no ano anterior.

P2) De janeiro a outubro de 2004, P2 emitiu 1,3 vezes mais propostas, $25 \%$ superior ao resultado do mesmo periodo no ano anterior.

P3) De janeiro a outubro de 2004, P3 emitiu 13 vezes mais propostas, $1200 \%$ a mais em relação ao mesmo período no ano anterior.

\section{Propostas Aceitas:}

P1) Comparando os dois periodos, o número de propostas aceitas também aumentou 8 vezes, ou $700 \%$. No período anterior ao programa (T0) o índice de aprovação das propostas emitidas foi de $1,4 \%$. No periodo seguinte (T1) o índice subiu para $50 \%$.

P2) Comparando os dois períodos, a quantidade de propostas aceitas também aumentou 2 vezes, ou 100\%. No período anterior ao programa (T0)o índice de aprovação das propostas emitidas foi de $19 \%$. No período seguinte (T1) o indice subiu para $30 \%$. 
P3) Comparando os dois períodos, a quantidade de propostas aceitas também aumentou 4 vezes, ou 300\% em termos percentuais. No período anterior ao programa (T0) o indice de aprovação das propostas emitidas foi de $0 \%$. No período seguinte (T1) o índice subiu para $30 \%$.

\section{Evolucão de faturamento:}

P1) Em 2004, Pl registrou um aumento de $90 \%$ no seu faturamento, quase dobrando a receita em relação aos 10 primeiros meses de 2003.

P2) Em 2004, P2 registrou um aumento de 19\% no seu faturamento, 1,2 vezes superior em relação aos 10 primeiros meses de 2003.

P3) Em 2004, P3 registrou um aumento de 55\% no seu faturamento, 1,6 vezes superior em relação aos 10 primeiros meses de 2003.

\section{Insercões na mídia:}

P1) Em 2004, Pl esteve na mídia o dobro de vezes em relação ao mesmo período no ano anterior, o que significou um aumento de $100 \%$.

P2) P2, em 2004, esteve na mídia o dobro de vezes em relação ao mesmo período no ano anterior, registrando também um aumento da ordem de $100 \%$.

P3) P3, em 2003, não registrou nenhuma aparição na mídia. Em 2004 esteve na mídia uma vez apenas.

\section{Palestras e apresentacões:}

P1) Em 2004, P1 concedeu 3,5 vezes mais apresentações e palestras em relação ao mesmo periodo de 2003 , o que significou um aumento de $250 \%$.

P2) Em 2004, P2 concedeu 2,5 vezes mais apresentaçôes e palestras em relação ao mesmo período de 2003 , o que significou um aumento de $150 \%$.

P3) P3 não concedeu palestras, apresentações ou seminários em ambos os periodos. 


\section{Pesquisa de satisfaç̃o de clientes:}

P1) No ano de 2003, P1 não estava no grupo de profissionais avaliados pelos clientes. No ano de 2004 os clientes que o avaliaram se consideraram satisfeitos.

P2) Em ambos os períodos, P2 recebeu avaliações positivas dos clientes, os quais se consideraram satisfeitos com seu atendimento e com a qualidade dos seus serviços.

P3) Em ambos os períodos (T0 e T1), P3 recebeu avaliações positivas dos clientes. Todos se declararam satisfeitos com o atendimento e com a qualidade dos serviços prestados.

\section{Resultados de avaliações de desempenho:}

Para melhor compreensão dos resultados obtidos, é necessário elucidar a escala de notas do sistema de gestão do desempenho. Tal escala abrange desde situações em que a competência não se aplica ao nivel de carreira (1); situações em as competências do avaliado não atendem à complexidade da posição (2); situações em as competências do avaliado atendem à complexidade da posição, porém com restrições (3); situações em as competências do avaliado atendem plenamente à complexidade da posição (4); situações em as competências do avaliado superam parcialmente à complexidade da posição (5) e situações em as competências do avaliado superam a complexidade da posição (6). Além da avaliação do seu orientador, os profissionais em desenvolvimento foram avaliados por mais dois gestores.

Os três profissionais em desenvolvimento apresentaram evolução nos resultados da avaliação do seu desempenho relativo às competências trabalhadas na ADC.

\subsection{Análise do desempenho do programa no período estudado}

Pode-se observar que nenhum dos indicadores definidos para avaliar o programa teve resultado negativo. Os profissionais em desenvolvimento apresentaram progresso em praticamente todos os resultados.

A quantidade de visitas de relacionamento, negócios e prospecção mais que dobraram para dois dos profissionais em desenvolvimento (P1 e P2) e cresceu quatro vezes para outro (P3). Isso indica aumento da disposição para a prática da auto-exposição, para 
exercitar a capacidade de percepção de oportunidades de novos negócios, bem como a habilidade de relacionamento com os clientes.

A quantidade de propostas emitidas também apresentou crescimento significativo em termos de eficiência. $\mathrm{P} 1$ emitiu mais que o dobro de propostas. $\mathrm{P} 3$ cresceu em 13 vezes. $\mathrm{O}$ crescimento de P2 foi menor em termos absolutos, porém verificou-se que no período anterior, seu desempenho em emissão de propostas já era quatro vezes maior que Pl e 28 vezes maior que $\mathrm{P} 3$.

Com relação à quantidade de propostas aprovadas e convertidas em negócios, comparando os dois períodos, $\mathrm{Pl}$ passou de $1,4 \%$ para $50 \%$ de aprovação das propostas emitidas. P2 passou de $0 \%$ para $30 \%$ e $\mathrm{P} 3$ passou de $19 \%$ para $30 \%$. Os resultados indicaram crescimentos no índice de eficácia dos esforços revelados pelos resultados do indicador anterior.

Embora os trabalhos da ADC para o desenvolvimento das competências de orientaçào para mercado e para clientes tenham iniciado apenas há pouco mais de doze meses,

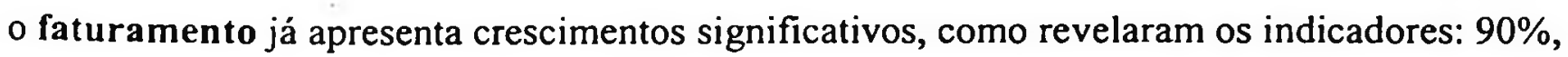
$19 \%$ e $55 \%$ para $\mathrm{P} 1$, P2 e P3, respectivamente.

As atividades de comunicação da imagem institucional (mídia, palestras, seminários e apresentações em geral), uma das maneiras de se trabalhar a marca da empresa respeitando o código de ética da categoria profissional, apresentaram crescimentos significativos.

Com relação ao indice de inserções na mídia, P1 e P2 cresceram $100 \%$ e P3 em $50 \%$. Juntos, os profissionais em desenvolvimento colocaram a empresa na imprensa (TV, rádio, jornais e revistas) 17 vezes, 2 vezes mais que o período anterior, significando mais de uma aparição por mês. No ranking geral da empresa em inserções na mídia os profissionais P1 e P2 empataram em primeiro lugar.

Quanto à comunicação da imagem institucional através da concessão de palestras, seminários, aulas e apresentações em geral, a contribuição de $P 1$ foi 3,5 vezes maior que o período anterior e a de P2, 2,5 vezes maior. P3 não realizou esse tipo de atividade em virtude dos problemas advindos da gravidez de risco.

No período anterior ao programa $A D C$, a pesquisa de satisfação dos clientes atendidos pelos profissionais em desenvolvimento apresentava um cliente insatisfeito, na última pesquisa todos se declararam satisfeitos. Isso indica comprometimento do grupo com a qualidade de serviços e relacionamento com os clientes. A percepção da evolução desses 
profissionais é ratificada pelo gerente de CRM (customer relationship management), responsável pela aplicação e tabulação da pesquisa.

O desempenho dos três profissionais quanto às competências foco do programa passaram de um índice abaixo de 4 , que no sistema de gestão do desempenho significa a existência de restrições, para índices acima de 4, o que significa superação parcial.

O crescimento desses profissionais, apontado pelo resultado das avaliações, se potencializa, quando se considera o fato de todos terem sido promovidos na carreira durante 0 período estudado. Promoções, no plano de carreira significam aumento das exigências das aplicações de suas competências.

Analisando os resultados em temos de grupo (Quadro 15), as médias de evolução foram significativas: todas acima de $50 \%$.

\begin{tabular}{|c|c|c|c|c|c|c|c|c|}
\hline \multicolumn{6}{|c|}{ MÉDIA - EVOLUÇO GERAL DO GRUPO NAS COMPETÉNCIAS FOCO DA ADC } \\
\hline $\begin{array}{c}\text { EVO- } \\
\text { LUÇĀO }\end{array}$ & $\begin{array}{c}\text { VISITAS } \\
\text { CLIENTES E E } \\
\text { PROSPECTS }\end{array}$ & $\begin{array}{c}\text { PROPOS- } \\
\text { TAS } \\
\text { EMITIDAS }\end{array}$ & $\begin{array}{c}\text { PROPOS- } \\
\text { TAS } \\
\text { ACEITAS }\end{array}$ & $\begin{array}{c}\text { FATURA- } \\
\text { MENTO }\end{array}$ & $\begin{array}{c}\text { INSERÇÕES } \\
\text { NA MIDIA }\end{array}$ & $\begin{array}{c}\text { PALESTRA, } \\
\text { SEMINARIOS } \\
\text { E APRESENT. }\end{array}$ & $\begin{array}{c}\text { PESQ. } \\
\text { SATISF. DE } \\
\text { CLIENTES }\end{array}$ & $\begin{array}{c}\text { DESEM- } \\
\text { PENHO }\end{array}$ \\
\hline $\mathrm{X}$ & 2,6 & 1,8 & 3,7 & 1,5 & 2,1 & 3,0 & $1(-)$ & 3,7 \\
\hline$\%$ & 159 & 78 & 267 & 53 & 113 & 200 & $100 \%(+)$ & 4,7 \\
\hline
\end{tabular}

Quadro 15: Resultado conjunto dos profissionais em desenvolvimento Fonte: Autora.

Os resultados em termos de conjunto indicam envolvimento e comprometimento dos profissionais com o desenvolvimento das suas competências e com a busca de resultados para o alcance dos objetivos organizacionais. É importante observar que o desenvolvimento de P3 foi excelente, diante do problema da gravidez de risco, que se desenvolveu durante o periodo em estudo, forçando-a a muitos períodos de licença até a realização do parto no último mês de dezembro.

Analisados os dados coletados, segue-se o capítulo de apresentação das conclusões. 


\section{CAPÍTULO 6}

\section{CONCLUSÕES E IMPLICAÇÕES}




\subsection{CONCLUSÕES}

\subsubsection{Sobre a experiência da aplicação do sistema de GC:}

Pela evolução dos resultados obtidos, revelados pelos indicadores selecionados, houve progresso no desempenho dos profissionais, de onde se pode entender que houve desenvolvimento de competências e que esse desenvolvimento interferiu positivamente no seu desempenho.

Os resultados da pesquisa indicaram, portanto, que o modelo conceitual de GC vem cumprindo o objetivo ao qual se propôs: o desenvolvimento de competências individuais e organizacionais.

A eficácia do sistema de gestão do conhecimento para o desenvolvimento de competências é evidenciada não só pelos resultados positivos revelados pelos indicadores, mas também pelos registros dos depoimentos dos entrevistados, que declaram o seu reconhecimento pela contribuição significativa do programa ADC no desenvolvimento das competências dos profissionais em desenvolvimento, para que esses resultados fossem alcançados.

Também deve ser registrado que o programa atingiu resultados adicionais àqueles aos quais se propôs, em relação aos profissionais em desenvolvimento. Tanto os profissionaismodelo, quanto os profissionais convidados declararam-se beneficiados pelo programa para 0 desenvolvimento das próprias competências.

Os conhecimentos desenvolvidos na ADC já formam uma base de conhecimento organizacional, pois os temas discutidos e trabalhados estão registrados e os responsáveis por eles encontram-se mapeados no sistema, de forma a estar acessivel para outros profissionais da organização. Compõe também a base do conhecimento organizacional o "manual do padrão de atendimento a clientes" produzido pelos integrantes do grupo que, no momento, encontra-se em fase de finalização.

Essa base é pequena ainda, mas a curva ascendente dos indicadores sugere que a multiplicação de orientadores levará a organização a disseminar conhecimentos em todos os niveis para formar de maneira consistente as suas competências estratégicas. A pesquisa deve continuar para analisar o desempenho e os resultados do programa em um periodo de tempo 
maior, em que seja possivel avaliar os profissionais, ora em desenvolvimento, na posição de orientadores, bem como avaliar o aumento da amplitude do alcance do programa.

\subsubsection{Sobre o modelo conceitual de sistema de GC}

A análise da aplicação prática do modelo conceitual de GC funcionou como um processo de retroalimentação, proporcionando subsídios para reavaliá-lo e consolidá-lo como instrumento de gestão.

A análise dos resultados permitiu concluir que o encadeamento de ações do sistema (Figura 17) - criação de significado do conhecimento a ser desenvolvido, provimento de informações para formação do conhecimento individual, conversão do conhecimento individual para o aprendizado em grupo, disseminação do conhecimento do grupo para os demais níveis da organização e aplicação do conhecimento desenvolvido - vai propiciar a formação das competências individuais e das competências organizacionais.

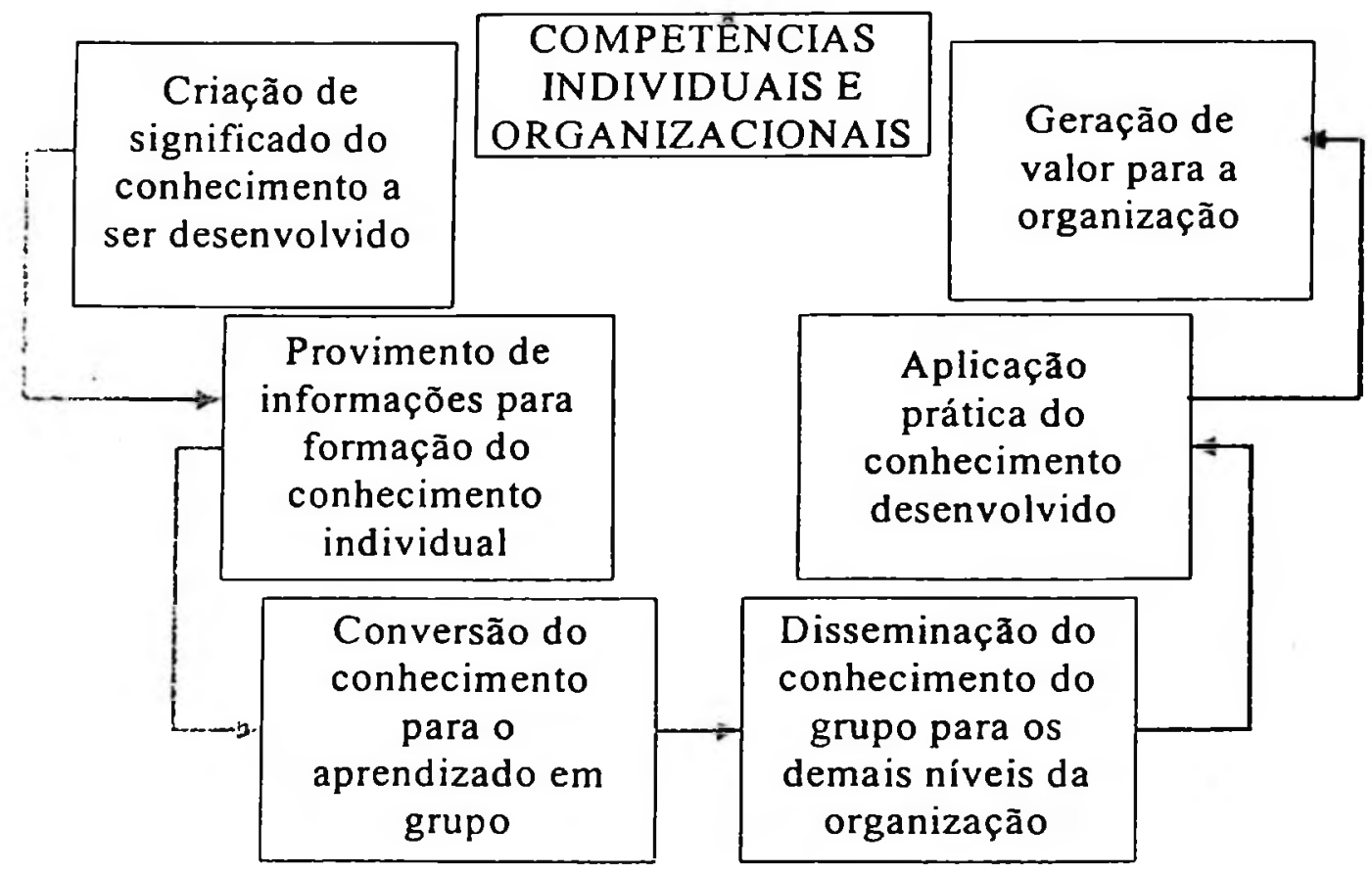

Figura 17: Ações encadeadas do sistema de GC para o desenvolvimento de competências

Fonte: Autora 
A seguir são apresentadas as conclusões sobre cada esfera do modelo conceitual de gestão do conhecimento (Figura 15, p. 85, reproduzida abaixo).

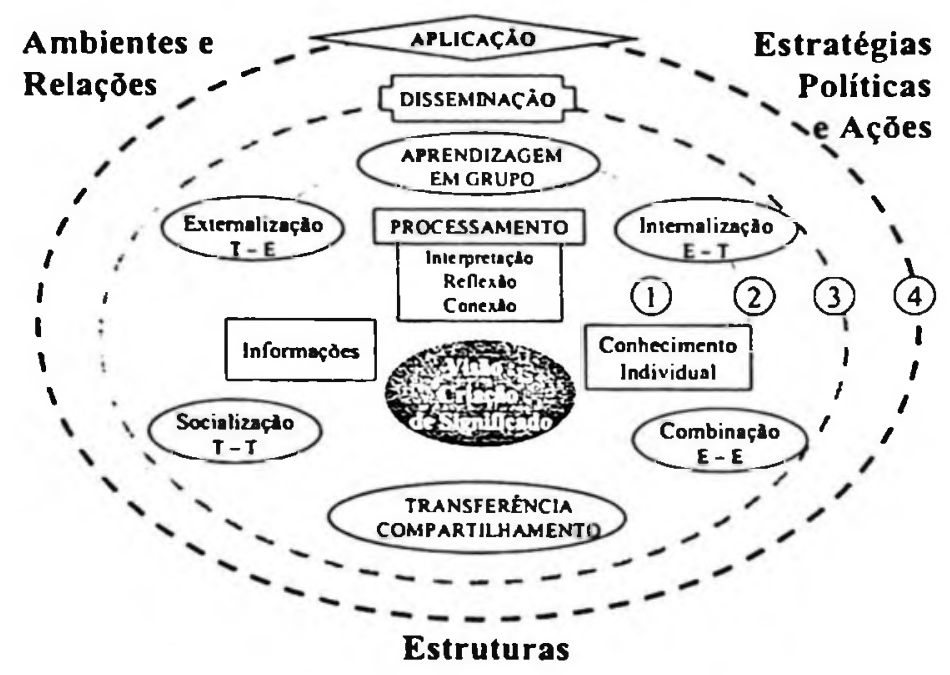

\subsubsection{Sobre o núcleo}

Compartilhar a visão do futuro planejado, entender o que é necessário para que ele se concretize e qual a responsabilidade de cada um nessa trajetória é o ponto de partida para o sucesso de um empreendimento em grupo, principalmente no que tange à formação de competências organizacionais.

Saber que conhecimentos deverão ser desenvolvidos, compreender onde e como o conhecimento que está sendo desenvolvido vai ser aplicado é a base para o envolvimento e comprometimento dos participantes na empreitada da formação das competências organizacionais para a consecução dos seus objetivos.

Muito embora, apenas alguns profissionais selecionados participam da ADC, todos os colaboradores foram envolvidos nas ações de compartilhamento da visão e criação de significado.

O envolvimento de todos os colaboradores na criação da visão compartilhada sobre necessidade de desenvolvimento dos conhecimentos, pode ampliar as condições de criação de um clima propício ao aprendizado e ao desenvolvimento. No ambiente organizacional as pessoas trabalham juntas, se relacionam, conversam, trocam informações e se observam e, muitas vezes se auxiliam. O fato de todos compartilharem a visão do futuro planejado e 
conhecerem o significado das competências necessárias pode favorecer a disseminação informal do conhecimento que ocorre naturalmente, de forma não sistematizada, pela troca de informações, pela observação, pela imitação.

As ações de promoção da visão compartilhada do futuro desejado e do conhecimento necessário para concretizá-lo, não se concentraram apenas nesses workshops, que foram o ponto de partida do programa. Elas continuam nos programas de integração de cada novo colaborador admitido pela empresa.

Alguns processos que precederam a implementação do sistema de GC na empresa estudada funcionaram como ações preparatórias, que formaram a base de sustentação do programa ADC. São os processos de elaboração do padrão referencial de competências e os processos de mapeamento da situação para identificação das deficiências. Eles foram construidos de forma alinhada às estratégias e objetivos organizacionais. Foi um desenvolvimento integrado, com o envolvimento de vários profissionais. Foi aí que se iniciou o processo de conscientização das pessoas, quanto à validade e importância das competências a serem desenvolvidas para o seu crescimento profissional e para o sucesso dos negócios da empresa. O fato de se realizar um trabalho de maior profundidade com os líderes evidencia a importância dada pela empresa ao papel da liderança na formação da cultura, na criação da visão do futuro e na implementação das estratégias organizacionais.

Os resultados e as percepções do grupo sobre as ações de compartilhamento da visão para a criação de significado, concentradas no núcleo do sistema, corroboram os conceitos teóricos de Senge (1990), Nonaka; Takeuchi (1997), Perez-Bustamente (1999) e Von Krogh; Ichijo; Nonaka (2001).

\subsubsection{Sobre a primeira esfera}

O provimento de informações mostrou-se de grande importância no processo. Foi uma preparação importante para as fases seguintes, pois ninguém cria conhecimento do nada. Conforme argumentam Loenard-Barton; Swap (1999), a criatividade só brota quando o "solo mental" estiver muito bem preparado. Receber informações e processá-las é a base da criação do conhecimento, é a preparaçào do "solo mental". O caso em estudo demonstrou isso, pois envolveu profissionais da área do direito com pouquissima ou nenhuma informação sobre conceitos de marketing, mercados, clientes, concorrentes etc. Esses conceitos tiveram que ser 
apresentados, desmistificados por meio de discussões, debates, esclarecimentos diversos para uma categoria profissional cuja cultura apresenta indícios de rejeição às atividades de venda, prospeç̧ão de clientes, desenvolvimento de mercado e outras ações de marketing.

\subsubsection{Sobre a segunda esfera}

As ações da segunda esfera, criadas com base nos conceitos de aprendizagem em grupo de Senge (1995), de abrasão criativa de Leonard-Barton; Swap (1999), conexão analógica de Sarvary (1999) e gerenciamento de conversas de Von Krogh; Ichijo; Nonaka (2001), mostraram seu peso na conversão do conhecimento para o aprendizado em grupo por meio dos diálogos e raciocínio coletivo, verificados nas reuniões de compartilhamento.

Embora os participantes reconheçam a importância de provimento de informações para formação do conhecimento individual ( $1^{\mathbf{a}}$ esfera), em seus depoimentos os entrevistados demonstram um entusiasmo bem maior com as atividades desenvolvidas nesta segunda esfera. Esse fato revela a supremacia da força do grupo em relação à força individual neste empreendimento de desenvolvimento do conhecimento e de formação das competências organizacionais.

Além do clima propício para o aprendizado em grupo, esta fase do sistema propiciou em várias situações excelentes condições para a economia de tempo na busca de soluções para os problemas dos clientes. No caso estudado, isso pode favorecer a criação da imagem pela qual a empresa quer ser reconhecida no mercado (fornecer soluções de valor com rapidez $\mathrm{e}$ criatividade). Os profissionais participantes do programa lidam com problemas e soluções diferentes em uma gama de clientes dos mais variados tipos e segmentos. As experiências vivenciadas nessas situações diversas promovem o desenvolvimento de determinados conhecimentos e habilidades que poderão ser adaptados e reutilizados em outras situações, para solucionar outros tipos de problemas, confirmando os conceitos de conexão analógica de Sarvary (1999).

Também ficou evidente a importância do acompanhamento dos profissionais-modelo pelos profissionais em desenvolvimento. Se os profissionais em desenvolvimento não tivessem tido a oportunidade para vivenciar determinadas situações, para observar seus orientadores em plena atuação, não teriam desenvolvido certas habilidades ou conhecimentos tácitos, cujo aprendizado ocorre pela observação, imitação e prática. 


\subsubsection{Sobre a terceira esfera}

Com base nos conceitos de Hansen, Nohria; Tierney (1999) quanto a estratégias de disseminação, o modelo do sistema de GC elaborado para este estudo baseou-se na personalização (personalization strategy). Adotou a abordagem person-to-person, cujo foco é o diálogo entre pessoas, que se mostrou adequada para o fomento da conversão do conhecimento para aprendizagem em grupo. O processo vem ocorrendo por meio de conversas pessoais e reuniões presenciais (reuniões de compartilhamento) e experiências conjuntas (acompanhamento dos orientadores).

A abordagem people-to-document tem sido explorada pelo modelo como suporte para registrar informações sobre soluções de serviços e sobre as pessoas que detêm determinadas competências, ou experiência em determinadas situações, para facilitar o contato entre as pessoas para fomentar a troca de conhecimentos, principalmente tácitos. Isso reflete os argumentos de Hansen; Nohria; Tierney (1999), sobre a escolha de uma estratégia principal, tendo a outra como suporte.

\subsubsection{Sobre a quarta esfera}

Com relação à quarta esfera, confirmou-se a importância do ambiente de apoio (solicitude, estímulo a risco, tolerância a erros e concessão das orientações necessárias), para que os profissionais em desenvolvimento pudessem aplicar na prática os seus conhecimentos e consolidar suas competências. São corroborados os conceitos de Le Boterf (2003), para quem a competência não é um estado, mas uma ação. Uma ação competente que resulta da combinação de recursos pessoais (conhecimentos, habilidades, qualidades, experiências, capacidades cognitivas, recursos emocionais etc.) e recursos do meio (tecnologia, banco de dados, livros, redes de relacionamento etc.).

É nesta esfera que o conjunto dos conhecimentos desenvolvidos na ADC são combinados e utilizados para produzir uma ação competente (LE BOTERF, 2003), ou um valor agregado (FLEURY, 2002), ou uma entrega de valor (DUTRA, 2001), ou um desempenho de performance superior (MCCLELLAND, 1973).

Adicionalmente, funcionou como elemento de incentivo o fato de se registrar toda atividade realizada por esses profissionais, que demandasse a aplicação das competências 
foco do programa, para compor indicadores, os mesmos apresentados no item 4.4. (p. 105). A apresentação periódica e discussão dos resultados desses indicadores com os profissionais em desenvolvimento e seus orientadores, serviram como estímulo e orientação na prática das competências em desenvolvimento. $O$ estabelecimento de relações entre o desenvolvimento do conhecimento e a performance econômica ou valor organizacional, segundo Davenport; De Long; Beer, (1998), é um indicador que está associado sucesso para os projetos de GC.

Somando as contribuições da literatura ao resultado da análise da aplicação do modelo, concluiu-se que, para o fomento à aplicação dos conhecimentos, a quarta esfera do sistema de GC deve abranger um conjunto de ações, que se revelou eficaz para incentivar os orientados a utilizar na prática de suas atividades os conhecimentos trabalhados na ADC. Esse conjunto de ações envolve uma combinação de estímulo ao risco, tolerância a erros, suporte dos orientadores e de outros participantes (retaguarda de apoio), somada à utilização de indicadores que mensuram as atividades que demandam as competências foco do programa (clima de desafio), conforme ilustra a Figura 18.

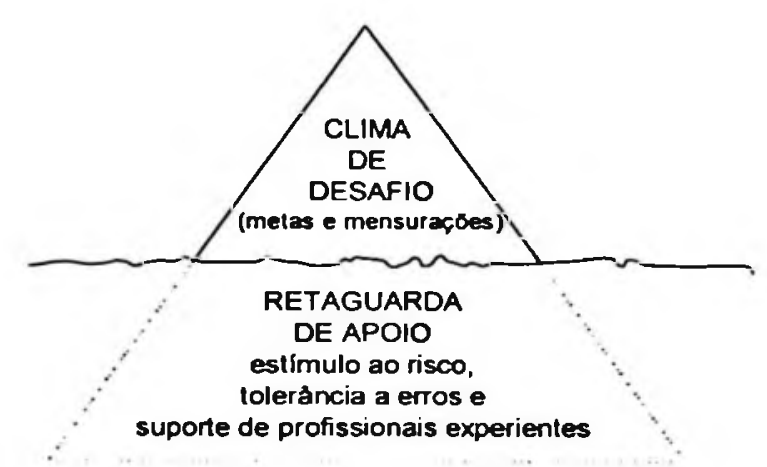

Figura 18: Esquema de incentivo à aplicação do conbecimento Fonte: Autora

\subsubsection{Sobre outros reflexos da literatura no modelo}

Os quatro modos de conversão do conhecimento de Nonaka; Takeuchi (1997), (externalização, combinação, socialização e internalização) permeiam praticamente todos os 
processos envolvidos nas esferas do modelo conceitual de GC aplicado no programa ADC, incluindo o núcleo.

A espiral do conhecimento de Nonaka; Takeuchi (1997) foi a espinha dorsal do modelo. Tal como os autores definiram, a criação do conhecimento e das competências começou no nível do indivíduo, com o provimento de informaçð̃es e as ações de fomento ao processamento interno das mesmas, na primeira esfera. Através da interação dos quatro modos de conversão do conhecimento, foco da segunda esfera do modelo, ocorreu a conversão do conhecimento individual em um processo de aprendizado em grupo. Pela capacitação dos profissionais em desenvolvimento para se tornarem orientadores, os profissionais-modelo se multiplicarão para orientar e desenvolver outros profissionais. Dessa forma os conhecimentos que formam as competências vão atingindo gradativamente grupos cada vez maiores (terceira esfera), para então se difundir para toda a organização.

Esses conceitos foram consolidados, caracterizando-se como recursos elementares para transferência do conhecimento individual, para o aprendizado em grupo, para a disseminação e para a formação do conhecimento e das competências organizacionais.

Quanto às cinco fases do processo de criação do conhecimento organizacional, $o$ compartilhamento do conhecimento tácito, a criação de conceitos, a justificação desses conceitos, a construção de um arquétipo e a difusão interativa do conhecimento de Nonaka; Takeuchi (1997), a ordem proposta pelos autores sofreu uma pequena inversão nas duas primeiras fases para atender as necessidades de desenvolvimento das competências definidas para o programa ADC.

A criação de conceitos (realizada na $1^{\text {a }}$ esfera do modelo) precedeu as demais fases, com o objetivo de introduzir as matérias de orientação para mercado e para clientes. Os conceitos foram criados pela externalização do conhecimento tácito dos instrutores e a internalização foi estimulada por meio de debates e dinâmicas vivenciais. $O$ compartilhamento do conhecimento tácito veio em seguida nas reuniões de compartilhamento e no acompanhamento dos orientadores pelos orientados.

Aplicação prática do modelo conceitual permitiu concluir que a criação do conhecimento organizacional deve se iniciar pela criação de significado do conhecimento a ser criado ou desenvolvido. Isso se torna possível pelo compartilhamento da visão do futuro planejado, pela conscientização da situação presente e pela compreensão das competências necessárias para que o futuro planejado se concretize. 
Em sua teoria de Nonaka; Takeuchi (1997) corroboram essa necessidade de criar significado pelo conceito da intenção, definida como a aspiração de uma organização às suas metas. A idéia da intenção envolve a conceitualização de uma visão sobre o tipo de conhecimento que deve ser desenvolvido (p. 83). Porém, os autores colocam a intenção como uma das condições capacitadoras, não como uma das fases do processo de criação do conhecimento organizacional.

O presente estudo de caso evidenciou a importância da criação de significado como primeiro passo do processo de formação do conhecimento $e$ das competências organizacionais.

Essa fase é seguida da criação de conceitos, traduzida no fornecimento das informações, que serão processadas (interpretadas, refletidas e conectadas) pelos aprendizes para a criação do conhecimento individual.

Depois disso o compartilhamento do conhecimento tácito se verifica nas atividades práticas desenvolvidas na segunda esfera.

A justificação dos conceitos também ocorreu na prática, podendo ser percebida nas atividades desenvolvidas nas reuniōes de compartilhamento, onde se reforça a importância da aplicação prática dos conceitos criados para o alcance dos objetivos organizacionais.

A construção de um arquétipo, fase em que, segundo Nonaka; Takeuchi (1997), o conceito justificado é transformado em algo concreto e tangível, pode ser verificada na elaboração do manual do padrão de excelência em serviços. Porém, em se tratando do setor de serviços, principalmente serviços de alto grau de intangibilidade, o arquétipo nem sempre se traduz em algo concreto. $O$ grau de tangibilidade do arquétipo também varia como, por exemplo, a construção de novo método de trabalho (mais tangivel) ou a construção de novas soluções para oferecer aos clientes e ao mercado (mais intangivel).

A difusão interativa do conhecimento verifica-se principalmente nas atividades dos profissionais-modelo, no seu papel de orientadores, bem como nas atividades de instrução ministradas por profissionais experientes, nas atividades criação de significado e de provimento de informações (primeira e segunda esfera).

Sobre ambientes e relações: o ambiente de liberdade e ajuda mútua, criado entre os integrantes da $\mathrm{ADC}$, minimizou a resistência dos mesmos em se abrir, ampliando a coragem para correr o risco de exteriorizar suas deficiências em termos de conhecimentos e competências. Os próprios orientadores e convidados utilizam o espaço das reuniōes de 
compartilhamento para trocar idéias e obter opiniões dos colegas sobre os próprios trabalhos. Isso indica que o programa propicia internamente, entre os seus participantes, condições para o intercâmbio de conhecimentos e experiências entre os profissionais de todos os níveis, quando as necessidades de ajuda são encaradas como compartilhamento. Não foi avaliado o ambiente externo ao programa.

Sobre estruturas: e estudo não revelou impactos da estrutura hierárquica sobre os resultados do programa, porém, o fato dos niveis se reduzirem a apenas dois (orientadores e orientados), pode ter favorecido a criação do ambiente de compartilhamento. Já os impactos da estrutura fisica foram verificados no fato de orientadores e orientados estarem alocados em ambientes separados. O compartilhamento do mesmo ambiente no dia-a-dia do trabalho, e não só em momentos específicos, acelera o processo de desenvolvimento das competências dos profissionais em desenvolvimento, por ampliar significativamente as oportunidades de aprendizado pela observação e imitação. A infra-estrutura de comunicação é condição básica para os processos de gestão do conhecimento e formação de competências organizacionais. Se as informações são consideradas a matéria prima do conhecimento, a comunicação é o meio pelo qual elas são transmitidas. Isso é consenso entre os estudiosos do assunto e ficou evidente no caso estudado.

Sobre ações gerenciais: o estudo confirmou a importância da existência de ações gerenciais estratégicas (Quadro 4, p. 35) para fortalecer e apoiar os processos envolvidos no sistema de GC. No caso em estudo destacam-se:

- compartilhamento da missão, da visão de futuro, dos objetivos e estratégias, bem como do conhecimento necessário para a implementação das estratégias e alcance dos objetivos organizacionais, com todos os seus colaboradores;

- concessão de autonomia aos profissionais, no que se refere a relações com clientes e na construção das soluções personalizadas oferecidas;

- estímulo ao risco e tolerância a erros;

- promoção da livre fluência de idéias entre os integrantes da ADC;

- valorização da diversidade e da heterogeneidade cognitiva;

- adequação dos sistemas de gestão de pessoas ao padrão referencial 
No presente estudo, não ficou evidenciada a existência de obstáculos significativos ao desenvolvimento das competências, causados por possíveis desalinhamentos entre as políticas de gestão e as estratégias e objetivos organizacionais. No entanto, há fortes indicativos levantados pela literatura, comprovados por meio de casos reais, sobre os danos que esse desajuste pode causar na formação da cultura do aprendizado e do conhecimento.

\subsubsection{Considerações gerais}

O objetivo geral do trabalho foi atingido. O modelo conceitual de gestão do conhecimento para o desenvolvimento de competências foi construído e implementado, permitindo a análise da sua aplicação prática.

A aplicação prática do modelo conceitual de CG permitiu observar que a criação de significado se revelou mais uma fase importante no processo de criação/desenvolvimento dos conhecimentos para a formação das competências organizacionais. São elementos necessários para a criação de significado do conhecimento a ser criado ou desenvolvido:

- o compartilhamento da visão do futuro planejado,

- a conscientização da situação atual em comparação com esse futuro e

- a compreensão da necessidade de se criar ou desenvolver determinados conhecimentos e competências para concretizar o futuro planejado.

Também se revelaram muito importantes as ações de definição das competências necessárias para a implementação de estratégias que levassem à concretização dos objetivos organizacionais.

Com base nos resultados do estudo de caso, somados às contribuições da literatura pesquisada, este estudo propõe que as competências organizacionais podem ser formadas a partir da criação ou desenvolvimento do conjunto dos conhecimentos que a compõem. Esse processo ocorre em 4 etapas:

- criação de significado para o(s) conhecimento(s) a ser(em) desenvolvido(s) ou criado(s);

- provimento de informações para a formação do conhecimento individual;

- conversão do conhecimento individual para o aprendizado em grupo; 
- disseminação do conhecimento os demais níveis da organização e

- aplicação do conhecimento criado ou desenvolvido.

A definição do conjunto dos conhecimentos que compõem as competências necessárias à concretização do futuro planejado é condição essencial para que o sistema cumpra o seu papel. A definição correta dos conhecimentos necessários para a trajetória do presente ao futuro planejado direciona o sistema e fundamenta o estabelecimento de prioridades, evitando que se dissipe energia com aspectos secundários ou desnecessários.

Importante observar que, em comparação com os projetos desenvolvidos por grandes empresas de consultoria e assessoria, apresentados no item 1.3.1. (p. 47), o modelo construído e testado neste estudo não demanda altos investimentos em tecnologia, em estrutura ou em pessoas envolvidas na sua implementação.

Os resultados desta pesquisa indicaram que, em apenas um ano de funcionamento do modelo, já se verificam resultados de valor para a empresa. Ao contrário do que relata Dunford (2000) sobre o depoimento de sócios da Booz, Allen \& Hamilton de que, de todos os programas implementados, uma parcela muito pequena apresentou impactos significativos para a empresa no curto prazo. Pode ser que para os altos investimentos realizados pelas grandes empresas de consultoria e assessoria em seus sistemas de GC, o tempo de retorno seja mais demorado (item 1.3.1., p. 50).

Dunford (2000) também coloca que há uma falta de tempo generalizada que não permite que os profissionais registrem seus aprendizados e experiências para alimentar o sistema para que outros possam compartilhar. As atividades desenvolvidas no programa ADC ocorrem em reuniões específicas e a estratégia foca a transferência e o compartilhamento do conhecimento pelo contato pessoal (person-to-person). Dessa os participantes não precisam dedicar tempo fora do programa para atividades de registro.

Vários autores destacam ainda a existência de um desafio maior: a criação de uma cultura organizacional que favoreça as práticas de gestão do conhecimento. Essa cultura está sendo criada dentro do grupo que integra a ADC. Se o conhecimento e as competências são trabalhados em um processo de aprendizado em grupo e, pelos quatro modos de conversão de Nonaka; Takeuchi (1997), atingem gradativamente grupos maiores até se difundir para os demais níveis da organização, do mesmo modo a cultura do conhecimento poderá ser extrapolar os limites do grupo para se difundir para os demais níveis da organização. 
Ressalta-se que, depois da criação do significado e do provimento de informações, nào se verifica no modelo conceitual aplicado o término de uma fase para início da outra. As fases se sobrepõem e coexistem simultaneamente no tempo. A continuidade se verifica em todas as esferas do sistema, que têm um ponto de início no tempo, mas não têm um ponto de término. O caráter de continuidade e simultaneidade foi reconhecido como uma estratégia de consolidação mais rápida do conhecimento. Criado o significado e fornecidas as informações, estas passam por um processo interno que envolve interpretação, reflexão e conexão para a formação do conhecimento individual. Em seguida essas informações, que já compõem o conhecimento individual, são trabalhadas em grupo e encaixadas em fatos concretos pelo compartilhamento de conhecimentos e experiências. Ao mesmo tempo, o conhecimento em formação já é aplicado em situações reais. Dessa forma, os indivíduos podem, em um mesmo periodo de tempo, receber e processar informações para a formação do seu conhecimento, compartilhar seus conhecimentos e experiências, aprender com o grupo e imediatamente aplicar o conhecimento criado ou desenvolvido. O depoimento dos envolvidos no programa ADC evidencia o sentimento do grupo sobre essa contribuição para o desenvolvimento das competências.

O caráter de continuidade evita a obsolescência do conhecimento, favorecendo a renovação constante da base do conhecimento organizacional, de maneira que ela esteja sempre evoluindo e acompanhando as mudanças do ambiente e suas novas demandas. Resgatando Kandampully (2002), um recurso valioso hoje pode deixar de ser no futuro, se algum novo conhecimento desenvolver um substituto superior.

Outro aspecto relevante da formação das competências organizacionais é que as pessoas que integram a organização estão em estágios diferentes em termos de conhecimentos e competências. Muitas vezes o conhecimento já existe no grupo, não havendo a necessidade de criá-lo, mas apenas desenvolvê-lo, ou ainda providenciar condições para que ele seja compartilhado, transferido, disseminado para outros níveis. 


\subsection{IMPLICAÇÕES}

\subsubsection{Implicações práticas}

Dependendo da maneira que se der prosseguimento ao programa $\mathrm{ADC}$, a empresa estudada poderá, sem grandes dificuldades, desenvolver vantagem competitiva em relação aos seus concorrentes, no que se refere à gestão e desenvolvimento de pessoas, cujo grau de importância para o setor de serviços é indiscutível.

Deve-se também atentar para a importância do alinhamento de todas as ações dos sistemas de gestão (gestão do negócio, gestão de pessoas, gestão do conhecimento etc.) com as estratégias e objetivos organizacionais. Se uma das partes do sistema falhar ou estiver desalinhada, as demais sofrerão os impactos dessa falha.

O cenário no setor de serviços jurídicos é favorável para quem sair na frente e os profissionais, na empresa estudada, se mostraram desejosos de aprender e se desenvolver. Esses são fatores importantes que não devem ser ignorados, visto que as pessoas no setor de serviços, principalmente em consultoria e assessoria, trazerem em si a matéria prima, a essência do produto: seus conhecimentos, suas competências e sua vontade de colocá-los em prática a serviço das organizações, gerando resultados de valor.

Definir que competências e que conhecimentos serão desenvolvidos pelo sistema de $\mathrm{CG}$ (modelo utilizado na $\mathrm{ADC}$ ) é pré-requisito para sua implementação. Muitos problemas ou desperdícios de tempo poderão advir de um processo de definição precário ou equivocado.

O processo de formação das competências organizacionais, conforme o modelo conceitual aplicado e analisado, tem início na criação de significado do conhecimento a ser desenvolvido ou criado para que se concretize o futuro planejado.

Há que se reconhecer, no entanto, o alto grau de dependência que as empresas têm das pessoas, seus conhecimentos e competências individuais, para a composição da base do conhecimento e das competências organizacionais, principalmente no contexto de serviços. Essa consciência por parte das lideranças deve preceder a criação de significado, pois são as pessoas que dão materialidade às competências organizacionais ao colocarem em prática seus conhecimentos, suas competências, alimentadas pelo manancial do conhecimento 
organizacional e pelos recursos colocados à sua disposição. Cabe às organizações a tarefa de identificá-las e promover o seu desenvolvimento.

O presente estudo oferece mais uma ferramenta para a prática da gestão por competências, da gestão do conhecimento e para a criação de diferenciais para o desenvolvimento de vantagem competitiva. Uma ferramenta que pode gerar valor para as empresas, principalmente as do setor de serviços jurídicos, considerando-se o estágio em que se encontram com relação a práticas de gestão.

O modelo construído apresenta aspectos de versatilidade, podendo ser utilizado no desenvolvimento de conhecimentos variados (teóricos, práticos, técnicos ou cognitivos), mesmo aquele localizado em níveis mais subjetivos dos indivíduos, o conhecimento tácito. Os resultados verificados pelos indicadores, levantados na pesquisa de campo, evidenciam essa possibilidade.Embora o modelo tenha sido testado em empresa do setor de serviços jurídicos, poderá também ser utilizado por outras empresas de diferentes setores e segmentos.

A facilidade de aplicação e os custos de implantação e manutenção relativamente baixos facilitam a sua adoção por empresas em qualquer estágio do seu desenvolvimento. Adicionalmente, poderá ser aplicado tanto para o desenvolvimento de competências de nível estratégico como para o desenvolvimento de competências de nivel operacional.

\subsubsection{Implicações acadêmicas}

O foco da maior parte da literatura pesquisada sobre a criação do conhecimento é a criatividade e a inovação. Diferente do presente estudo, cujo foco é a formação de competências organizacionais, considerando que competências sejam compostas por um conjunto de conhecimentos.

O levantamento literário dos temas competências e gestão do conhecimento, realizado de forma paralela permitiu analisar como ambos se integram e se complementam.

Se competências são constituídas por um conjunto de saberes que combinados resultam em ação competente, se esses saberes podem estar localizados ora em niveis mais subjetivos, ora em niveis mais objetivos (tácito ou explícito), se o termo saber significa ter conhecimento, então surge daí uma nova contribuição, trazida pelo presente estudo para o conceito de competências no contexto organizacional: 
Competências individuais consistem em um conjunto de conhecimentos combinados e colocados em prática a serviço da organização para gerar resultados de valor para os stakeholders.

Competência organizacional é a capacidade de conectar os indivíduos em uma rede de competência coletiva, capaz de criar vantagem competitiva, gerando efetivamente resultados de valor para o negócio e seus stakeholders.

Como evidenciam os resultados da pesquisa que compõe a parte empírica deste estudo, pode-se concluir que competências podem ser desenvolvidas utilizando-se conceitos e técnicas de gestão do conhecimento. Não se verifica no modelo nenhuma ação que isoladamente já não tenha sido tratada pela literatura. A efetividade do sistema está no caráter seqüencial, no encadeamento dessas ações. Dessa forma, o modelo do sistema de gestão do conhecimento elaborado neste estudo oferece mais uma contribuição para os estudos de gestão por competências e gestão do conhecimento.

Este trabalho poderá contribuir também para os estudos sobre a criação de uma cultura favorável à criação do conhecimento para a formação das competências organizacionais. $O$ fato de o grupo estudado ter desenvolvido aspectos dessa cultura, evidencia a possibilidade de formá-la pela a aplicação do modelo construído.

Fora do contexto organizacional, o modelo poderá ser testado também para fins educacionais. Em uma proposta bem simplificada: a criação do significado poderia ser realizada por meio de orientação vocacional, na primeira esfera estariam concentradas as aulas teóricas com cuidados especiais para maior envolvimento e participação dos alunos para o processamento interno das informações. Concentradas na segunda esfera estariam as atividades em grupo para compartilhamento de experiências e atividades vivenciais. $\mathrm{Na}$ terceira esfera a disseminação para grupos maiores seria concretizada pelas atividades didáticas dos professores e atividades de monitoria de alunos veteranos. Programas de estágio, programas tipo "empresa júnior" ou programas de prestação de serviços à comunidade pelos estudantes são exemplos de como se poderia compor a quarta esfera do modelo - a aplicação do conhecimento. 


\subsection{LIMITAÇÕES E SUGESTÕES PARA FUTURAS PESQUISAS}

A pesquisa deve continuar para analisar o desempenho e os resultados do programa em um periodo de tempo maior, em que seja possível avaliar os profissionais, ora em desenvolvimento, na posição de orientadores, bem como avaliar o desempenho do programa face ao aumento da amplitude do seu alcance.

A literatura evidencia que o ambiente, a cultura e o clima organizacional podem significar o sucesso ou o fracasso de sistemas de gestão do conhecimento. $O$ estudo abrangeu um grupo pequeno, cujas ações e reações eram mais facilmente acompanhadas e controladas. A interferência imediata da coordenação pode ter criado maiores chances de manter a motivação elevada. O grupo recebia também atenção diferenciada e o fato de fazerem parte da academia significava posição de destaque na empresa, minimizando impactos de possiveis desalinhamentos das políticas internas na motivação ou desenvolvimento do grupo. $O$ programa precisa ser analisado em um contexto maior para avaliar tais impactos.

Nesse âmbito maior, a identificação da cultura e clima da organização e seus impactos sobre o desempenho do programa é um tema a ser investigado em trabalhos futuros. O grau de impacto da visão compartilhada do futuro sobre o clima de aprendizado pode também ser um tema para futuras investigações.

A aplicação prática do modelo revelou indícios de desenvolvimento de uma cultura favorável à criação do conhecimento e, conseqüentemente, à formação das competências organizacionais. Tais indícios foram verificados através da análise dos dados sobre ambientes e relações, estrutura, estratégias, ações gerenciais e políticas.

Esse fato abre espaço para outro estudo a ser desenvolvido sobre a possibilidade aproveitamento do modelo para a formação de uma cultura do conhecimento. Considerando que está se formando dentro da $\mathrm{ADC}$ uma cultura favorável aos processos de GC, que essa cultura pode ser trabalhada e fortalecida entre os integrantes do programa, da mesma forma que o conhecimento e as competências, poderá extrapolar os limites do grupo para se difundir para os demais níveis da organização.

Fora do contexto organizacional, o modelo poderá ser testado também para fins educacionais, conforme proposto no último parágrafo da página 157. Estudos futuros poderão confirmar a eficácia dessa utilização. 
Adicionalmente, com base neste estudo de caráter exploratório, futuros estudos quantitativos poderão ser desenvolvidos. 


\section{REFERÊNCIAS BIBLIOGRÁFICAS}

ALAVI, M. KPMG Peat Marwick U.S.: One giant brain, case 9-397-108, Harvard Business School, Boston-MA, 1997.

ARGYRIS, C. Double Loop Leaming in Organizations. Harvard Business Review, Boston, v. 55, n. 5, p. 115-125, Sep./Oct. 1977.

ASHBY, W. R. An introduction to Cybernetics. Londres: Chapman \& Hall, 1956.

BARBOSA, A. C. Q. Um mosaico da gestão de competências em empresas brasileiras. RAUSP - Revista de Administração da USP, São Paulo, v. 38, n. 4, p. 285-297, out./nov./dez. 2003.

BARCLAY, R.O.; MURRAY, P. C. What is knowledge management. In: A knowledge Praxis. USA, 1997.

BARNEY, J. Gaining and sustaining competitive advantage. Upper Saddle River: Prentice Hall, 2002.

BARNEY, J. Firm resources and sustained competitive advantage. Journal of management. [S.I.], v. 17, n. 1, p. 99-120, 1991.

BARROSO, A. C. O.; GOMES E. P. Tentando entender a gestão do conhecimento. RAP Revista de Administração Pública. Rio de Janeiro, v. 33, n.2, p. 147-170, mar./abr., 1999.

BERG, B. L. Qualitative research methods for the social sciences. Needham Heights: Allyn \& Bacon, 1998.

BORANGA, A. L; LOVRO, M. R. Marketing e Advocacia - o papel do marketing no escritório de advocacia. Consultor Jurídico. Publicação 25 jun. 1998. Disponível em: <http://conjur.uol.com.br/textos/526/. Acesso em: 15 dez. 2004.

BROWN, T. et alii. The Customer orientation of service workers: personality trait effects on self- and supervisor performance ratings. Journal of Marketing Research, [S.1.], v. 39, p. 110119, Feb. 2002. 
BUKOWITZ, W. R.; WILliAMS, R. L. Manual de Gestão do Conhecimento. Porto Alegre: Bookman, 1999.

CHARD, A. M. Knowledge management at Ernest \& Young, Case S-M-291. Graduate Schoool of Business, Stanford University, 1997.

CHOO, C. W. A Organização do Conhecimento. São Paulo: Senac, 2003.

DAVENPORT, T. H.; DE LONG, D. W.; BEERS, M. C. Successful knowledge management projects. Sloam Management Review, Cambridge, v. 39, n. 2, p. 43-57, Winter, 1998.

; HANSEN, M. T. Knowledge management at Andersen Consulting, Case 9-499-032, Harvard Business School, Boston MA, 1998.

; PRUSAK L. P. Working Knowledge: how organizations manage what they know. Harvard Business School Press, Boston MA, 1998.

DODGSON, M. Organizational Learning: a review of some literatures. Organizational Studies, Berlin, v. 14, p. 375-394, 1993.

DRUCKER, P. A Survey of the Near Future. The Economist. New York, 3-20, Nov. $3^{\text {rd }}$, 2001 . . Sociedade Pós-Capitalista. São Paulo: Pioneira, 1994.

DUNFORD, R. Key challenges in the search for the effective management of knowledge im management consulting firms. Journal of Knowledge Management, Kempston, v. 4, n. 4, p. 295, 2000.

DUTRA, J. S.; Gestão por Competências: um modelo avançado para o gerenciamento de pessoas. São Paulo: Gente, 2001.

Competências: conceitos e instrumentos para gestão de pessoas na empresa moderna. São Paulo: Gente, 2004.

; HIPÓliTO, J. A. M.; SILVA, C. M. Gestão de Pessoas por Competências: o caso de uma empresa do setor de telecomunicações. RAC - Revista de Administração Contemporânea, Rio de Janeiro, v. 4, n.1, p. 161-176, jan./abr. 2000. 
EBOLI, M. O desenvolvimento das pessoas e a educação corporativa. In: FLEURY, M. T. (coord.). As Pessoas na Organização. São Paulo: Gente, 2002.

FERREIRA, A. B. H. Dicionário da Lingua Portuguesa. Rio de Janeiro: Nova Fronteira, 1980.

FLEURY, A.; FLEURY, M. T. Aprendizagem e Inovação Organizacional. São Paulo: Atlas, 1997.

FLEURY, M. T. L. Aprendizagem e gestão do conhecimento. In: DUTRA, J. S.; Gestão por Competências: um modelo avançado para o gerenciamento de pessoas. São Paulo: Gente, 2001.

FLEURY, M. T. L. A gestão de competência e a estratégia organizacional, In: FLEURY, M. T. (Coord.). As Pessoas na Organização. São Paulo: Gente, 2002.

FRENCH; J.R.P.; RAVEN, B. The bases of social power. In: CARTWRIGHT, D. Studies in social power. Ann Arbor, Mich: Institute for Social Research, 1959.

BRUM, B. L. R. Análise Setorial: escritórios de advocacia, São Paulo: Gazeta Mercantil, fev. 2002, v. I - Estrutura e Mercado.

GIL, A. C. Como Elaborar Projetos de Pesquisa. São Paulo: Atlas, 1994.

2002 . Técnicas de Pesquisa em Economia e Elaboração de Monografias. São Paulo: Atlas, . Métodos e Técnicas de Pesquisa Social. São Paulo: Atlas, 1989.

HANSEN, M. T.; NOHRIA N.; TIERNEY, T. What's your strategy for managing knowledge. Harvard Business Review, Boston, v. 77, n. 2, p. 106-1 16, Mar./Apr. 1999.

HARTLINE, M.D.; FERREL, O. C. The management of customer-contact service employees: an empirical investigation. Journal of Marketing, Chicago, v. 60, p. 52-70. Oct. 1996.

HENDERSON, B. D. As origens da estratégia. In: MONTGOMERY, C. A; PORTER, M. E. (orgs.). Estratégia: a busca da vantagem competitiva. Rio de Janeiro: Elsevier, 1998. 
HOEREM, T.; VON KROGH, G.; ROSS, J. Knowledge-Bassed Strategic Change.. In: VON KROGH, G; ROSS, J. (Eds.) Managing Knowledge - perspectives on cooperation. London: Sage Publications, 1996.

KANDAMPULLY, J. Innovation as the core competency of a service organization: the role of technology, knowledge and networks. European Journal of Innovation Management, Bradford, v. 5, n. 1, p. 18-26, 2002.

KING, A. W.; FOWLER, S. W.; ZEITHAML, C. P. Competências organizacionais e vantagem competitiva: o desafio da gerência intermediária. RAE-Revista de Administração de Empresas, São Paulo, v. 42, n. 1, p. 36-49, jan./mar. 2002.

KOGUT, B.; ZANDER, U. Knowledge of the firm, combinative capabilities and the replication of technology. Organizational Science. Linthicum, v. 3, n. 3, p. 383-397, August 1992.

KOTLER, P.; ARMSTRONG, G. Introdução ao Marketing. Rio de Janeiro: LTC, 2000.

LAWLER III, E. E. From job-based to competency-based organizations. Journal of Organizational Behavior, Chichester, v. 15, n. 1, p. 3-15, J. 1994.

LE BOTERF, G. Desenvolvendo a Competência dos Profissionais. Porto Alegre: BookmanArtmed, 2003.

LEONARD-BARTON, D.; SWAP, W. When Sparks Fly. Boston: Harvard Business School Press, 1999.

LEVIT, T. Marketing intangible products and product intangibles. Harvard Business Review, Boston, v. 59, n. 3, p. 94-102, May/June 1981.

LETHBRIDGE, T. O ataque ao Brasil. Portal Exame, São Paulo, 30 jul. 2004. Ed. 823. Disponivel em: http://portalexame.abril.com.br/edicoes/823/negocios/conteudo_45144.shtml. Acesso em: $15 \mathrm{dez} .2004$.

LOURES, C. A. S. Um estudo sobre o uso da evidência fisica para gerar percepçōes de qualidade em serviço. São Paulo, 2003. Dissertação (Mestrado em Administração) Faculdade de Economia, Administração e Contabilidade, Universidade de São Paulo. 
MARTINS, G. A.; PINTO, R. L. Manual para Elaboração de Trabalhos Acadêmicos. São Paulo: Atlas, 2001.

MCLAGAN, P. A., Competencies: The next generation. Training and Development, [S.1.], v. 5l, n. 5, p. 40-47, May 1997.

. Competency Models: great ideas revisited. Training and Development, [S.1.], v. 50, n. 1, p. 60-64, Jan. 1996.

MCCLELLAND. D. C. Testing for competence rather than intelligence. Americam Psychologist, [S.1], p. 1-14, Jan. 1973.

MERTON, R. K. Social Theory and Social Structure (rev. and enlarged ed.). New York: Free Press, 1968.

NACHMIAS, C. F.; NACHMIAS, D. Research Methods in the Social Sciences $\left(4^{\text {th }}\right.$ ed.). New York: St Martin's Press, 1992.

NONAKA, I.; TAKEUCHI, H. A Criação do Conhecimento nas Empresas: como as empresas japonesas geram a dinâmica da inovação. Rio de Janeiro: Campus, 1997.

ORDEM DOS ADVOGADOS DO BRASIL. Código de Ética e Disciplina. Versão 2003.

PERES-BUSTAMENTE, G. Knowledge management in agile innovative organizations. Journal of Knowledge Management, Kempston, v. 3, n. 1, p.6, 1999.

PORTER, M. E. Competitive Strategy. New York: Free Press, 1980.

Como as forças competitivas moldam a estratégia. In: MONTGOMERY, C. A; PORTER, M. E. (Orgs.). Estratégia: a busca da vantagem competitiva. Rio de Janeiro: Elsevier, 1998.

PRAHALAD, C. K.; HAMEL, G. The Core Competence of the Corporation. Harvard Business Review. Boston, v. 68, n. 3, p. 79-91, 1990.

PRINGLE, E.G. Do proprietary tools lead to cookie cutter consulting? Journal of Management Consulting, [S.1.], v. 10, n.1, p. 3-7, 1998. 
RANKING da Advocacia. Consultor Jurídico, São Paulo, 19 jul. 2004. Disponível em: $<$ http://conjur.uol.com.br/textos/247898/>. Acesso em: 15 dez. 2004.

ROBBINS, S. Comportamento Organizacional. Rio de Janeiro: LTC, 1999.

SARVARY, M. 1999. Knowledge Management and Competition en the consulting Industry. California Management Review, California, v. 4, n. 2, p. 95-107, Winter, 1999.

SCHEIN, E. H. Organization Psychology, $3^{\text {rd }}$ ed. Prentice Hall: Englewood Clifs, 1988.

SELEM, L. C. A. Estratégia na Advocacia: planejamento para escritórios de advocaciauma ferramenta para competir. Curitiba: Juruá, 2003.

SELLTIZ, C. et alii. Métodos de pesquisa nas relações sociais. São Paulo: EDPU, Universidade de São Paulo, 1974.

SENGE, PETER. 1990. A Quinta Disciplina. São Paulo: Best Seller, 1990.

SIEGEL, R. S. Managing design consulting firms to survive in tough times. Design Management Journal, Boston, v. 14, n. 3, p. 48-55, Summer, 2003.

SPENDER, J. C. Gerenciando Sistemas de Conhecimento. In: FLEURY, M. T. L.; OLIVEIRA JR, M. M. Gestão Estratégica do Conhecimento: Integrando aprendizagem, conhecimento e competências. São Paulo: Atlas, 2001.

TERRA, J. C. C. Gestão do Conhecimento: aspectos conceituais e estudo exploratório sobre as práticas de empresas brasileiras. In: FLEURY, M. T. L.; OLIVEIRA JR, M. M. Gestão Estratégica do Conhecimento: Integrando aprendizagem, conhecimento e competências. São Paulo: Atlas, 2001.

TIOLlenT, M. Pesquisa-Ação nas Organizações. São Paulo: Atlas, 1997. . Metodologia da Pesquisa-Ação. São Paulo: Cortez, 2004.

VASCONCELOS, F. C.; BRITO, L. A. L. Vantagem Competitiva: o construto e a métrica. RAE - Revista de Administração de Empresas, São Paulo, v. 44, n. 2, p. 51-63, abr./jun., 2004. 
; CYRINO, A. B. Vantagem Competitiva: os modelos teóricos atuais e a convergência entre estratégia e teoria organizacional. RAE - Revista de Administração de Empresas, São Paulo, v. 40, n. 4, p. 20-37, out./dez., 2000.

VON KROGH, G; ICHIJO,K.; NONAKA,I. Facilitando a Criação do Conhecimento: reinventando a empresa com o poder da inovação contínua. Rio de Janeiro: Campus, 2001 . Care in Knowledge creation. California Management Review, California, v. 40, n. 3, p. 133-153, spring 1998.

WANG, C. L.; AHMED, P.K. Structure and structural dimensions for knowledge based organizations. Measuring Business Excellence, Bradford, v. 7, n. 1, p. 51-62, 2003.

WEICK, K. E. The Nontraditional Quality of Organizational Learning. Organizational Science, Linthicum, v.2, n. 1, p. 116-124, 1991.

YIN, R.K. Estudo de caso - planejamento e métodos. Porto Alegre: Bookman, 2001.

ZARIFIAN, P. Objetivo Competência: por uma nova lógica. São Paulo: Atlas, 2001.

ZEITHAML, V. A.; BITNER, M. J. Marketing de Serviços: a empresa com foco no cliente. Porto Alegre: Bookman, 2003.

; PARASURAMAN, A.; BERRY, L. Problems and strategies in services marketing. Journal of Marketing, Chicago, v. 49, p. 33-46, 1985. 
APÊNDICES 


\section{APÊNDICE 1}

Lógica que une as informações coletadas aos objetivos do trabalho

\begin{tabular}{|c|c|c|}
\hline ITEM & $\begin{array}{l}\text { OBJETIVOS DO } \\
\text { TRABALHO }\end{array}$ & FONTES DE DADOS/EVIDÊNCIAS \\
\hline $\begin{array}{l}4.1 . \\
\text { Contextualização }\end{array}$ & $\begin{array}{l}\text { i) Analisar o contexto em que } \\
\text { a pesquisa se desenvolve. }\end{array}$ & $\begin{array}{l}\text { - Análise setorial publicada pela Gazeta Mercantil em } \\
2002 \text { (a mais recente). } \\
\text { - Livros e matérias publicadas em jornais e revistas sobre } \\
\text { o setor juridico. } \\
\text { - CD room institucional. } \\
\text { - Código de Ética da OAB (Ordem dos Advogados do } \\
\text { Brasil) } \\
\text { - Slides de apresentação da empresa. } \\
\text { - Relatórios de headcount. } \\
\text { - Programa de integração de novos colaboradores. } \\
\text { - Materiais produzidos no workshop de apresentação e } \\
\text { consolidação do modelo de gestão por competências. } \\
\text { - Documentos de divulgação da missão, visão de futuro e } \\
\text { objetivos organizacionais. }\end{array}$ \\
\hline $\begin{array}{l}\text { 4.2. A construção } \\
\text { do sistema de } \\
\text { gestão por } \\
\text { competências }\end{array}$ & $\begin{array}{l}\text { i) Analisar o processo de } \\
\text { elaboração do padrão } \\
\text { referencial de competências } \\
\text { organizacionais e individuais } \\
\text { que embasa o sistema de GC. }\end{array}$ & $\begin{array}{l}\text { - Slides de apresentação do modelo de gestão por } \\
\text { competências quando da sua concepção. } \\
\text { - Materiais produzidos no workshop de apresentação e } \\
\text { consolidação do modelo de gestão por competências. } \\
\text { - Projeto do sistema de gestão por competências. } \\
\text { - Documentos de divulgação da missão, visão de futuro e } \\
\text { objetivos organizacionais. }\end{array}$ \\
\hline $\begin{array}{l}\text { 4.2.1. O padrão } \\
\text { referencial e a } \\
\text { situação (ideal } x \\
\text { real) }\end{array}$ & $\begin{array}{l}\text { iii) Analisar o processo de } \\
\text { identificação das deficiências } \\
\text { das competências, cujo } \\
\text { desenvolvimento é o foco do } \\
\text { programa estudado. }\end{array}$ & $\begin{array}{l}\text { - Resultados do processo de mapeamento. } \\
\text { - Relatórios e memorandos sobre o assunto. }\end{array}$ \\
\hline $\begin{array}{l}\text { 4.3. Programa } \\
\text { ADC. }\end{array}$ & $\begin{array}{l}\text { iv) Analisar a aplicação } \\
\text { prática do modelo conceitual } \\
\text { de sistema de gestão do } \\
\text { conhecimento para o } \\
\text { desenvolvimento de } \\
\text { competências. }\end{array}$ & $\begin{array}{l}\text { - Projeto do programa ADC. } \\
\text { - Relatórios das reuniões de compartilhamento. } \\
\text { - Memorandos e correspondências internas e } \\
\text { - Observação direta e participante dos eventos que } \\
\text { integram o programa. }\end{array}$ \\
\hline $\begin{array}{l}\text { 4.4. Indicadores } \\
\text { de desempenho } \\
\text { do programa }\end{array}$ & $\begin{array}{l}\text { v) Definir e analisar } \\
\text { indicadores de desempenho } \\
\text { do programa. }\end{array}$ & $\begin{array}{l}\text { - Relatórios gerenciais, comerciais e financeiros. } \\
\text { - Relatórios de avaliação de desempenho. } \\
\text { - Pesquisa de satisfação de clientes. } \\
\text { - Registros de comunicação institucional. } \\
\text { - Documentos e registros em arquivo. }\end{array}$ \\
\hline
\end{tabular}




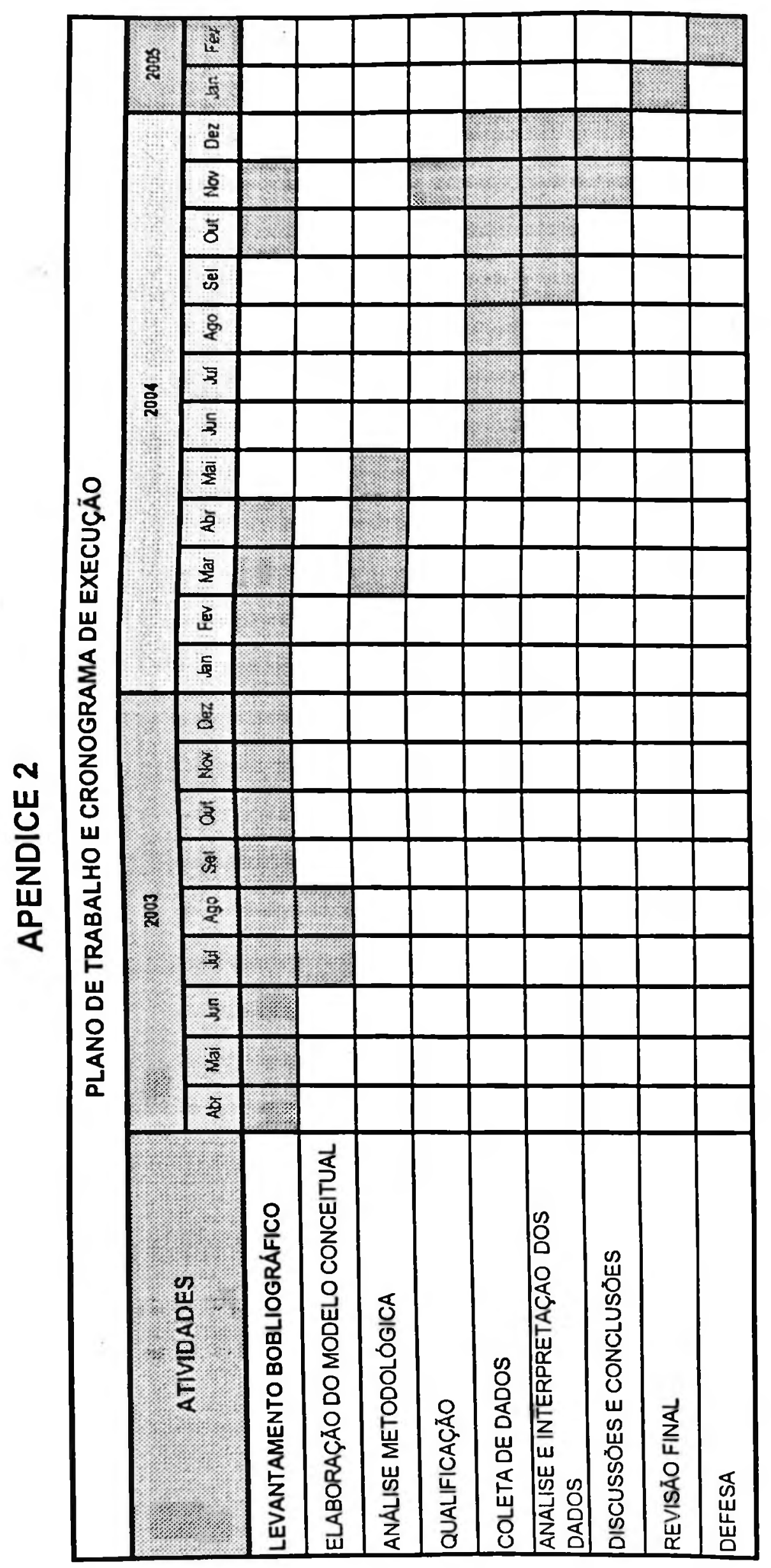




\section{APÊNDICE 3}

Lógica que une as informações coletadas aos objetivos do trabalho (continuação)

\begin{tabular}{|l|l|l|}
\hline ITEM & \multicolumn{1}{|c|}{$\begin{array}{c}\text { OBJETIVOS DO } \\
\text { TRABALHO }\end{array}$} & FONTES DE DADOS/EVIDÊNCIAS \\
\hline $\begin{array}{l}\text { 4.5. A percepção } \\
\text { dos integrantes da } \\
\text { ADC }\end{array}$ & $\begin{array}{l}\text { vi) Analisar o desempenho do } \\
\text { programa. }\end{array}$ & - Entrevistas. \\
$\begin{array}{l}\text { 4.6. Notas da } \\
\text { observação } \\
\text { participante }\end{array}$ & $\begin{array}{l}\text { - Observação participante. } \\
\text { Cap. S: Análise dos } \\
\text { dados coletados }\end{array}$ & Análise dos dados coletados. \\
\hline $\begin{array}{l}\text { 3.1. Elaboração do } \\
\text { modelo conceitual } \\
\text { do sistema de GC }\end{array}$ & $\begin{array}{l}\text { Objetivo Geral: elaborar um } \\
\text { modelo conceitual de sistema de } \\
\text { gestão do conhecimento para o } \\
\text { desenvolvimento de } \\
\text { competências individuais e } \\
\text { organizacionais e }\end{array}$ & \\
\hline $\begin{array}{l}\text { Cap. 5: Análise dos } \\
\text { dados coletados } \\
\text { Cap. 6: Conclusões } \\
\text { e implicações }\end{array}$ & $\begin{array}{l}\text { investigar sua aplicação prática } \\
\text { através de estudo de caso único } \\
\text { em empresa brasileira do setor } \\
\text { de serviços assessoria e } \\
\text { consultoria juridica. }\end{array}$ & Análise dos dados coletados. \\
\hline
\end{tabular}




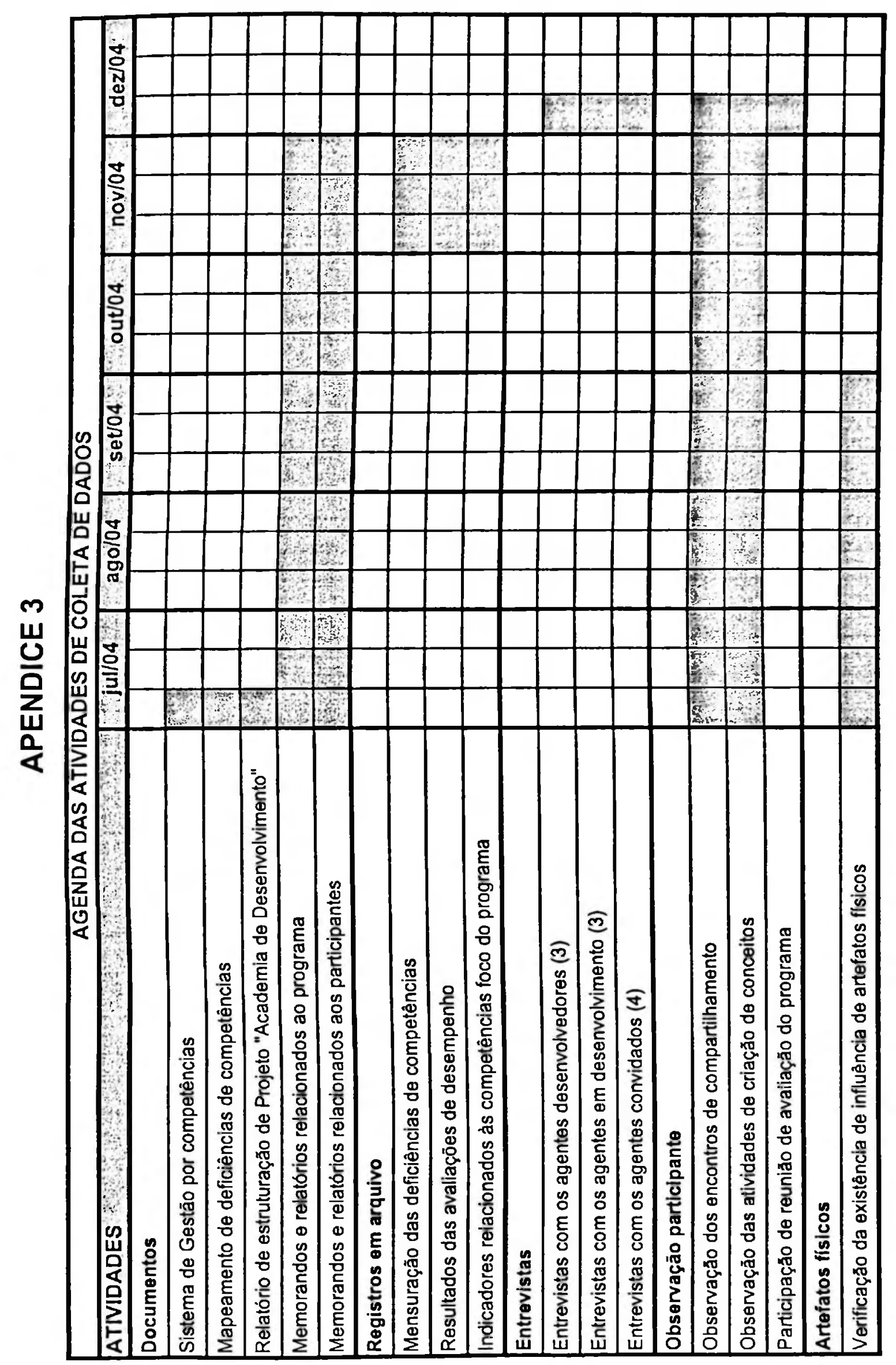


Em virtude de problemas ocomidos no processo de encadernação do trabalho, especificamente na tiragem de cópias, ficou prejudicada a nitidez da figura representativa do modelo conceitual de gestão do conhecimento, apresentada nas páginas 85, 100 e 144 do trabalho. Por essa razão, enviamos esta página adicional com a sua reprodução.

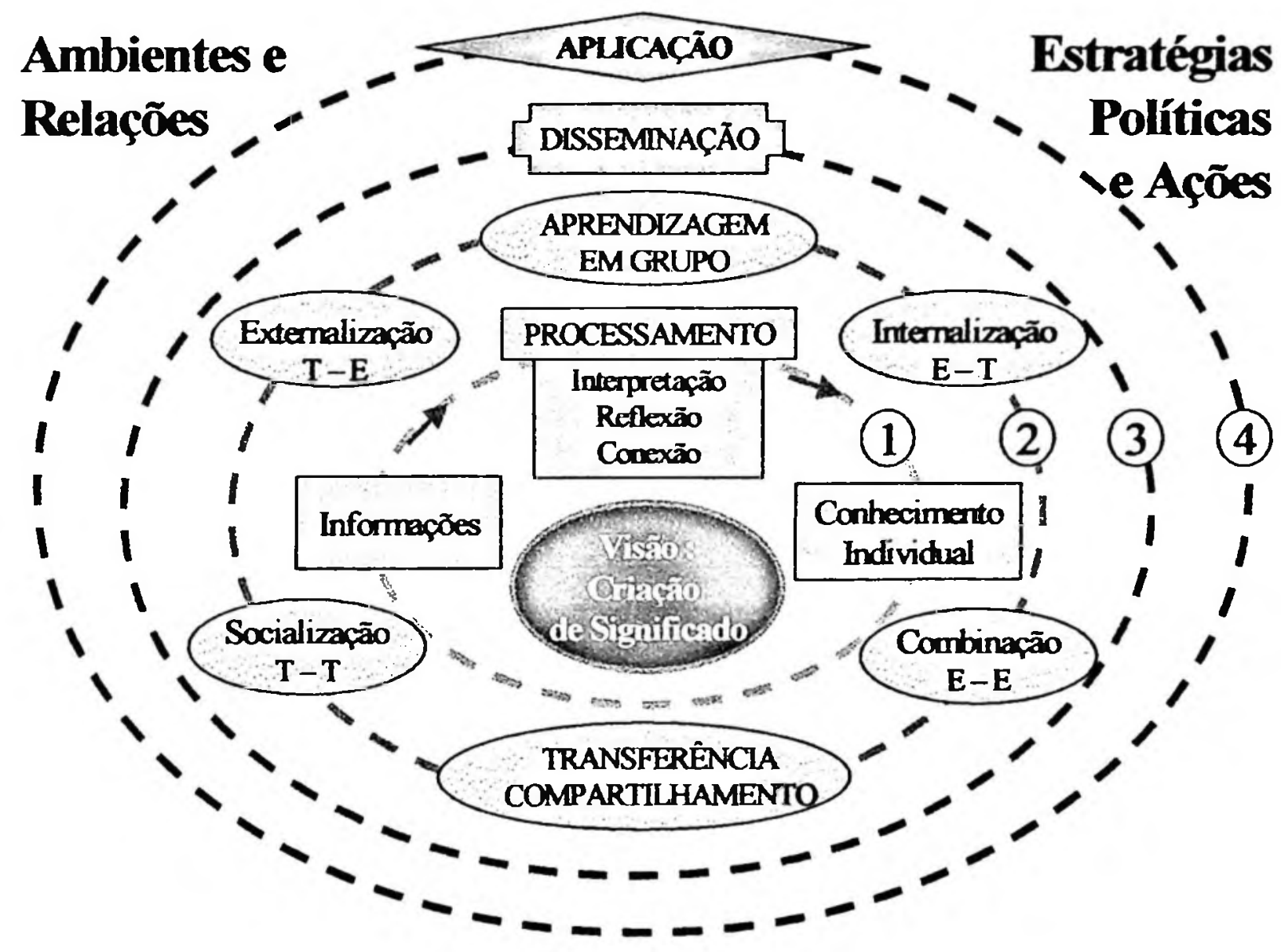

Estruturas 


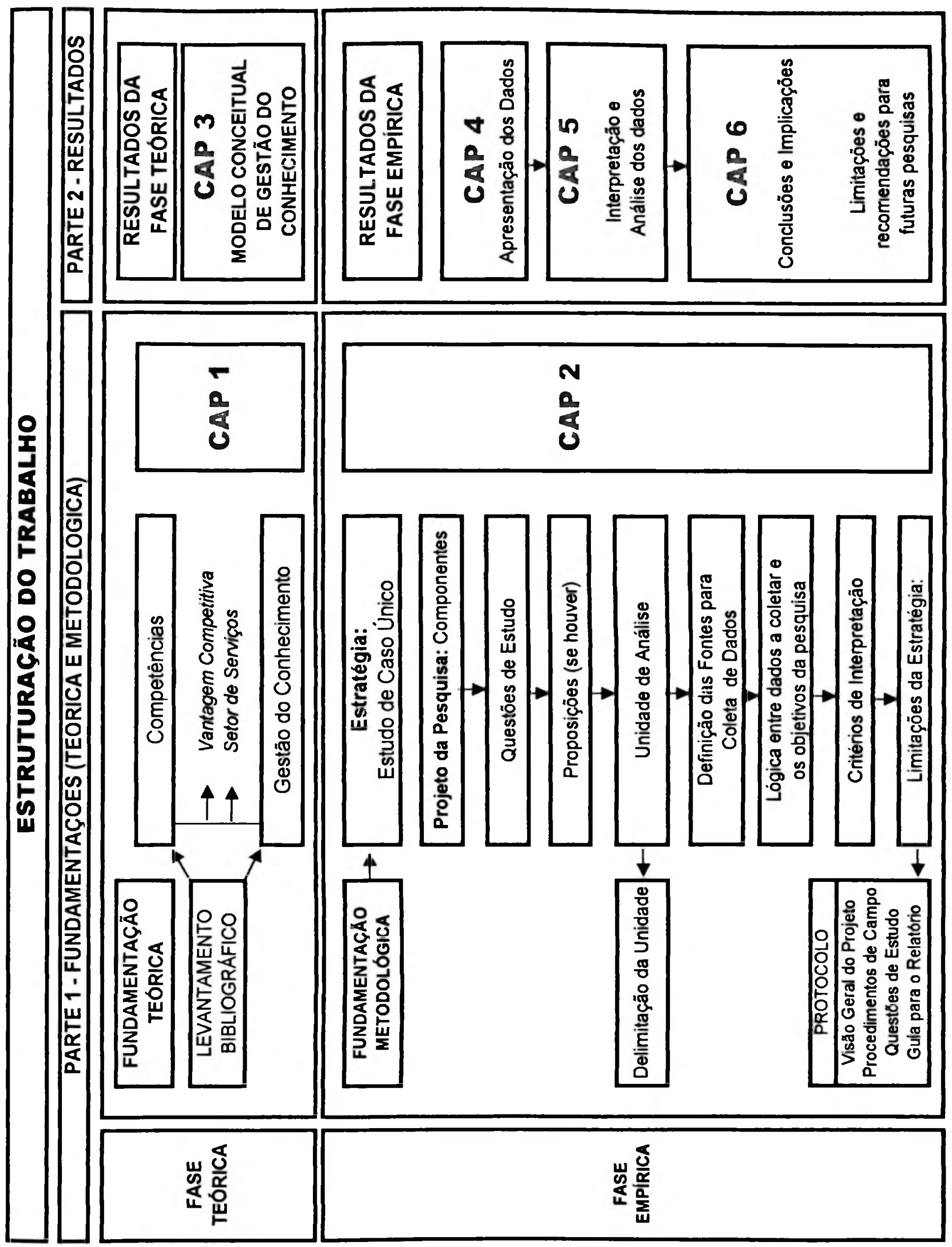

